\title{
Critical review on proteotypic peptide marker tracing for six allergenic ingredients in incurred foods by mass spectrometry \\ DOI:
}

10.1016/j.foodres.2019.108747

\section{Document Version}

Accepted author manuscript

Link to publication record in Manchester Research Explorer

Citation for published version (APA):

Pilolli, R., Nitride, C., Gillard, N., Huet, A-C., van Poucke, C., de Loose, M., Tranquet, O., Larré, C., Adel-Patient, K., Bernard, H., Mills, E. N. C., \& Monaci, L. (2020). Critical review on proteotypic peptide marker tracing for six allergenic ingredients in incurred foods by mass spectrometry. Food Research International, 128, 108747. https://doi.org/10.1016/j.foodres.2019.108747

\section{Published in:}

Food Research International

\section{Citing this paper}

Please note that where the full-text provided on Manchester Research Explorer is the Author Accepted Manuscript or Proof version this may differ from the final Published version. If citing, it is advised that you check and use the publisher's definitive version.

\section{General rights}

Copyright and moral rights for the publications made accessible in the Research Explorer are retained by the authors and/or other copyright owners and it is a condition of accessing publications that users recognise and abide by the legal requirements associated with these rights.

\section{Takedown policy}

If you believe that this document breaches copyright please refer to the University of Manchester's Takedown Procedures [http://man.ac.uk/04Y6Bo] or contact uml.scholarlycommunications@manchester.ac.uk providing relevant details, so we can investigate your claim.

\section{OPEN ACCESS}




\section{CRITICAL REVIEW ON PROTEOTYPIC PEPTIDE MARKER}

5 Rosa Pilolli ${ }^{1}$, Chiara Nitride ${ }^{2}$, Nathalie Gillard ${ }^{3}$, Anne- Catherine Huet ${ }^{3}$, Christof van Poucke ${ }^{4}$,

6 Marc de Loose ${ }^{4}$, Olivier Tranquet ${ }^{5}$, Collette Larré5 ${ }^{5}$ Karine Adel-Patient ${ }^{6}$, Hervé Bernard ${ }^{6}$, E.

$7 \quad$ N. Clare Mills², and Linda Monaci ${ }^{*}$

81 Institute of Sciences of Food Production, National Research Council of Italy (ISPA-

9 CNR), via Giovanni Amendola 122/O - 70126 Bari, Italy;

102 School of Biological Sciences, Division of Infection, Immunity and Respiratory

11 Medicine, Manchester Academic Health Science Centre, Manchester Institute of

12 Biotechnology, The University of Manchester, UK;

133 CER Groupe, Rue du point du Jour, 8, 6900 Marloie, Belgium;

144 Flanders Research Institute for Agriculture, Fisheries and Food, Brusselsesteenweg 15370,9170 Melle, Belgium;

165 UR1268 BIA, Rue de la Géraudière, BP 71627, 44316 Nantes, France;

176 INRA-CEA, Service de Pharmacologie et d'Immunoanalyse, Laboratoire d'Immuno18 Allergie Alimentaire, Bât. 136-CEA de Saclay, 91191 - Gif-sur-Yvette, France.

20 * corresponding author: linda.monaci@ispa.cnr.it

21 Tel: +39080 5929343 
24 Peptide marker identification is one of the most important steps in the development of a mass spectrometry (MS) based method for allergen detection, since the robustness and sensitivity of the overall analytical method will strictly depend on the reliability of the proteotypic peptides tracing for each allergen. The European legislation in place issues the mandatory labelling of fourteen allergenic ingredients whenever used in different food formulations. Among these, six allergenic ingredients, namely milk, egg, peanut, soybean, hazelnut and almond, can be prioritized in light of their higher occurrence in food recalls for undeclared presence with serious 31 risk decision.

32 In this work, we described the results of a comprehensive evaluation of the current literature on MS-based allergen detection aiming at collecting all available information about proteins and peptide markers validated in independent studies for the six allergenic ingredients of interest. The main features of the targeted proteins were commented reviewing all details available about known isoforms and sequence homology particularly in plant-derived allergens. Several

37 critical aspects affecting peptide markers reliability were discussed and according to this evaluation a final short-list of candidate markers was compiled likely to be standardized and 39 implemented in MS methods for allergen analysis.

40

41 Keywords: food allergens, mass spectrometry, peptide markers, ThRAll, incurred foods. 
IgE-mediated food allergies are steadily on the rise representing a huge health concern worldwide. Although firm prevalence data are lacking, there are extensive investigations suggesting that food allergies have increased and rates as high as approximately $10 \%$ have been documented, with main prevalence in industrialized countries, and in children compared to adults (Scott et al. 2018). There are many manifestations of food allergy with different severities, and individual investigations rely on specific study populations, specific foods, and different methodologies, thus impairing the determination of undoubted statistics. Moreover, further constrains in obtaining solid prevalence data, arise from geographic variations, diet exposure effects, differences according to age, race, and ethnicity, and myriad other factors. Like all chronic disease, onset of food allergy is influenced by genetics, environment and genome-environment interactions including epigenetics effects. Its current management is based on allergen containing food avoidance. Food labelling legislative provisions are available in several countries and require a detailed declaration of allergen inclusion in foods, with number and types of priority allergens differing among countries and depending on specific dietary habits and allergy prevalence. On the other hand, a precautionary labeling system is also widespread, representing a safety measure put in place from industries to protect from any accidental cross-contamination likely to occur in foods expected to be allergen-free and that can take place at whatever stage along the food chain. All this raised the urgent need to develop reliable methodologies to trace allergens in foods with the highest confidence. Mass spectrometry (MS) techniques have been widely exploited in the last ten years to meet this goal and were specifically applied to food allergen detection, and to the food allergen identification and characterization, as well. Despite the need for expensive equipment and trained personnel, 
the chance to provide multiplexing and unequivocal allergen identification accounts for the overall strength of the MS based approaches compared to previously established methods, such as immunoassays and DNA based methods. Nonetheless some gaps in the development of MS-based quantitative methods still need to be addressed. The review paper authored by Monaci et al., 2018 provides a comprehensive overview of the MS based methods developed so far for allergen detection and also highlights the need of harmonization in method development and validation.

In this frame, the European project ThRAll (Thresholds and Reference method for Allergen detection method) titled "Detection and quantification of allergens in foods and minimum eliciting doses in food allergic individuals", funded by the European Food Safety Agency will actively contribute to the advancement in harmonization of MS-based method for food allergen detection by developing a prototype quantitative reference method for the multiple detection of food allergens in standardized incurred food matrices (Mills et al. 2019). Five main food ingredients causing severe IgE-mediated reactions have been prioritized in light of their occurrence in food recalls (Turner et al., 2015; Worm et al., 2014; Bucchini et al., 2016). Milk, soybean, tree nuts, egg, and peanuts were selected as responsible for most alerts notified on the RASFF (Rapid Alert System for Food and Feed) portal for undeclared presence with serious risk decision. A recent notice from the European Commission (Commission Notice of 13.7.2017) relating to the provision of information on substances or products causing allergies or intolerances as listed in Annex II of Regulation (EU) No 1169/2011 provides specifications about how the Annex II of Regulation (EU) No 1169/2011 should be implemented. In particular, as for milk and egg ingredients the notice clarifies that the legislation should be applied to milk from all farmed animals and egg from all farmed birds. Given the timing of the ThRAll project, 
and the urgent demand for harmonization of current analytical methods, the Consortium agreed to prioritize cow's milk and hen's egg allergens, as first targets, also in light of their main role in the primary production. Indeed according to recent statistical data (FaoStat, 2017), cow's milk production represented in 2017 the $97 \%$ of total milk production in Europe and the $81 \%$ of the production worldwide. Similarly, in the same year the hen's eggs accounted for the $99 \%$ of total egg production in Europe and for the $82 \%$ worldwide. Whether the developed approach would be applicable to all farmed animals/birds will be specified depending on the final validated analytical markers. As for tree nuts allergens, two representative ingredients have been selected, hazelnut and almond, which are widely used in food manufacturing and represent foods of public health importance in Europe, causing severe reactions (Worm et al., 2014).

The allergenic ingredients will need to be incorporated into the food before being processed to mimic as closely as possible the manufacturing process. Two model matrices will need to be produced ad hoc in a food pilot plant, namely a chocolate bar and a broth powder. These latter are the representative food commodities responsible for recalls, namely baked goods, confectionary products and complex multiphase foods and pose specific challenges in MS based analytical detection. Both matrices were selected because they are extremely complex, with different features, having chocolate high contents of fat and polyphenols whilst broth powder is an extensive processed food (cooking, boiling and drying), enriched with proteins.

One of first tasks scheduled in the ThRAll project (Objective 1) concerns the identification of protein and peptide markers for the targeted allergenic ingredients. As a fact, markers identification is one of the most important steps in the method development. Different workflows are available to accomplish this objective and they have been reviewed in a recent paper 
111 authored by Downs \& Johnson in 2018. All issues besetting such choice including, various 112 ingredients formulations, extraction yield in thermally processed foods, and incomplete genomic 113 and proteomic sequence information, as well as all common issues associated with MS-based 114 protein quantitation were critically discussed. The main point raised by Downs \& Johnson was 115 that the target selection cannot be accounted by in-silico only approach. Methodological details, 116 such as matrix composition, protein extraction and digestion, should be taken into consideration 117 for marker selection, affecting both the specificity and sensitivity of the final analytical method. 118 The assessment on a model matrix is required firstly for specificity issue because interfering 119 peaks from the matrix background may cause false-positives; in addition the processing degree 120 of the investigated food matrix may also differently affect the target protein/peptide detection 121 resulting in false-negative which can pose safety risk for the allergic consumer. None of these 122 issues can be tackled by the solely in-silico based approach, thus the need for an empirical 123 validation of the candidate peptide markers in incurred foods (Monaci et al., 2018).

124 An alternative approach could rely on the comprehensive assessment of the allergen detection 125 literature, supported by the experimental evidence that if the same peptides for given allergenic 126 proteins have been detected in independent studies and in multiple matrices, they can likely be 127 standardized (Croote \& Quake, 2016). In order to promote this approach, an open-source 128 repository of discovery and targeted MS data on allergen detection and quantitation has been 129 developed and made available as public bioinformatic tool (Allergen Peptide Browser, 2018). 130 The database has been structured around proteins recognized by the World Health 131 Organization and International Union of Immunological Societies (WHO/IUIS) as food allergens. 
After a proper screening of the different available options, the partners of ThRAll consortium

133 agreed on undertaking peptide selection by applying a dual approach with different time scale:

134 (i) critical evaluation of the peptide markers already reported in the existing literature; (ii) 135 validation of the candidate peptide list by discovery analysis on the specific incurred matrices 136 under investigation (chocolate bars and broth powder). Herein, we will describe the results of 137 the first point, namely the comprehensive evaluation of the literature, providing a thorough 138 discussion about the application of general acceptance criteria for harmonization of the markers 139 selection step. The goal of this work is to draw a preliminary list of reliable peptide markers, 140 which will be validated later on by untargeted HR-MS/MS analysis of incurred matrices, 141 representing the bases for the selected reaction monitoring (SRM) based reference method 142 under development within the ThRAll project.

\section{Literature review based marker peptide selection}

145 The analytical workflow displayed in Fig. 1 was designed to provide the comprehensive evaluation of the current literature. It consists of five main steps aimed at the critical evaluation

147 of the information gathered from previous works and the proper selection of reported signature peptides according to specific criteria. We collected all information about the six allergens selected as targets in the ThRAll project (cow's milk, hen's egg, peanut, soybean, hazelnut, and almond) (step 1). Afterwards, the list of reported signature peptides have been evaluated 151 and filtered according to specific features, namely sequence length, matrix similarity with the 152 ThRAll project, kind of investigation (discovery only or targeted analysis) and occurrence of 153 amino acid residues prone to endogenous and exogenous modifications (step 2). The third step 
of the workflow consisted in retrieving all the information available for the relevant allergenic proteins (relative abundance, post-translational modification sites, protein isoforms and variants), from different informatics sources detailed in Figure 1. At step 4 peptide specificity was assessed by sequence alignment with other species searching not only for exact matches of tryptic peptides (performed for all candidate markers of the six allergenic ingredients) but also disclosing potential interference from sequence homology with single amino acid mismatches (performed only on the four plant-derived allergenic ingredients). Finally as last step of the analytical workflow, for the refined peptide list we collected experimental details about the MS-based detection, such as the instrumental platform, the precursor ions, and the selected transitions. Indeed, the peptide ionization efficiency and reproducibility, as well as the relative intensity of fragmentation pattern might be affected also by instrumental parameters which need to be assessed case-by-case. For the comprehensive assessment of the allergen detection literature (step 1 in Fig.1) we exploited the Allergen Peptide Browser (APB) database available online, and collected all information about the six allergens selected for the ThRAll project. The gathered information also integrated data fed by other studies based on MS/MS analysis with either ESI or MALDI ionization, encompassing the most recent publications not itemized yet on APB. A total of 89 papers were reviewed, published in the last twenty-five years, which resulted in an exhaustive list of tryptic peptides for milk (total 42 peptides), egg (total 62 peptides), peanut (total 50 peptides) and soybean (total 146 peptides), and a shorter, but still reasonable list for hazelnut (total 26 peptides) and almond (total 29 peptides) allergens (see Table S1). In the second step the full list was narrowed down according to specific constraints. A range of 7-20 amino acids (AA) in length was applied as good compromise between peptide specificity, ionization yield and reproducibility. About $84 \%$ of reported peptides were included 
177 in this range. Afterwards, we searched for matrix similarity with the ThRAll project, and marker 178 peptides that were never validated in either chocolate or highly processed incurred matrices 179 were rejected. The resulting peptides list is displayed in Fig. 2 and Fig. 3 (and itemized in Table 180 S2) together with details about the total number of citing papers per each peptide, and the kind 181 of investigation (targeted vs discovery approaches), marked with different color (orange and 182 blue, respectively).

183 The marker selection should comply with specific requirements that value the quantitative 184 information retrieved. Indeed, the allergen quantification depends on the concentration of 185 peptide markers, based on the assumption that the peptide is released completely from the 186 original protein with a specific stoichiometric ratio. Any unpredictable distribution of the released peptide into different precursor ions, for example due to amino acid modification or multiple ionization states, should be traced and susceptible peptides should be excluded, in case of low reproducibility. Concerning the exclusion of signature peptides containing labile amino acids prone to modifications, it deserves to be noted that the number of potential endogenous and exogenous post-translational modifications is huge, but their occurrence is highly variable; therefore, it is not a realistic goal neither to evaluate nor to exclude them all strictly, rather an empirical validation of the specific case study should be preferable. In this investigation, we focused on the occurrence of specific amino acids of major concern, such as methionine, asparagine, glutamine, and cysteine, excluding only peptide sequences containing methionine residues prone to processing-induce oxidation, and asparagine-glycine motifs prone to deamidation (Li et al., 2005; Li et al., 2006). We deemed important for the robustness of the analytical method to avoid M containing peptides as analytical targets, because such residue would be highly prone to oxidation, in thermally processed matrices, in barely predictable 
proportions. The NG motifs could be subjected to spontaneous deamidation in-vitro, however, in case of need the asparagine deamidation might be forced in order to convert all asparagine residues into aspartic acid. As for cysteine residues, most digestion protocols included a reduction/alkylation step (mainly based on dithiothreitol and iodoacetamide), preliminary to actual enzymatic proteolysis, which is specifically designed to break disulfide bridges and block irreversibly the cysteine residues by carbamidomethylation. Common sense is to consider this modification as complete however, in the perspective to avoid source of uncertainty, C containing peptides should be preferentially excluded unless the reliability of the peptide is duly assessed experimentally.

As third step of the analytical workflow reported in Fig. 1, starting from the refined list of peptide markers, we sought for additional information available on the target proteins, which could affect the detection sensitivity and reliability, such as relative abundance, natural post-translational modification (PTM), protein isoforms and variants, gathering data from different sources (either scientific publications or on-line databases, i.e. Uniprot, Allergome, WHO/IUIS).

Peptide specificity was assessed by BLAST search against the most common protein databases disclosing also potential detection interferences in plant-derived proteins (single amino acid mismatches) (step 4). The APB Database queried for this review of peptide markers, already provided information about sequence specificity, retrieved by means of BLAST 2.2.31+ (BLAST DB, Sep 20, 2016). Only hits with $100 \%$ identity and no gaps were retained for a given peptide, and the following constrains were applied to exclude hits: (i) bacterial super kingdom; (ii) absent species name or kingdom; (iii) species / common name entry containing: 'synthetic construct' or 'vector'; (iv) title containing 'partial' or 'fragment'. Since it was not clear whether 
222 they considered or not the site specific trypsin cleavage, we also double-checked the specificity

223 for all the six allergenic ingredients by means of the Protein Prospector tool developed by the

224 University of California San Francisco (http://prospector.ucsf.edu/prospector/mshome.htm, accessed

225 on October 24th 2018). In particular, the MS-Homology option searching for $100 \%$ identity of

226 tryptic peptides within the main databases, NCBInr.2013.6.17 and UniProtKB.2017.11.01, was

227 applied. In addition, for plant-derived allergens, protein homology among different taxonomies

228 needs to be considered very carefully. Besides the previously discussed full matches $(100 \%$

229 identity), in low-resolution MS detection potential interferences might raise also under particular

230 conditions, from peptides with single amino acid mismatches. Therefore, further BLAST search

231 against non-redundant protein database was carried out (access in July 2018), seeking for

232 single amino acid substitutions, which could result in differences of peptide molecular weight

233 within $\pm 1 \mathrm{Da}$ (for example, I/L, D/N, E/Q). These kind of substitutions might generate interfering

234 precursor ions isolated and activated at least partially in the set $\mathrm{m} / \mathrm{z}$ window, and might provide

235 several transitions, which are not distinguishable from the targeted peptides. Finally, as step 5

236 of the workflow we retrieved experimental details about the MS platform, the isolated ions and

237 the monitored transitions. As a fact, most tryptic peptides feature favorable ionization 238 properties, which provide high ionization efficiency and typically result in either double or triple 239 charged ions due to the occurrence of basic amino acid residues. However, some peptide 240 sequences may present multiple ionization routes resulting in a loss of sensitivity due to the 241 distribution of the total amount of released peptide in different precursor ions, each 242 characterized by a specific fragmentation pattern. Since we use as a calibrant the synthetic 243 natural version of the peptide and use as an anchor the ration measurement to the isotopic 244 labelled version of the peptide, the distribution among different charge state is accounted and 
245 thereof can be considered negligible. From the quantitative point of view, by selecting the most 246 intense precursor ions loss of sensitivity can be limited. Besides the amino acid sequence, 247 several experimental features may affect this ionization behavior, e.g. the electrospray source 248 parameters, the MS platform, the composition of the food matrix, dragging competing species 249 to the ionization step. Therefore it is crucial that the theoretical selection of candidate markers, 250 based either on the in-silico approach or on the literature review approach should be confirmed 251 by experimental validation on the specific MS platform and on the main matrices of interest.

252 In the sections below, we present the results of the analytical workflow reviewing all information 253 collected for the six allergens of interest.

\subsection{Proteins and peptide markers reported for cow's milk and hen's egg}

The inclusion of milk from domesticated mammalian animals, mainly cattle, buffalo, sheep, goat and camel, boasts a very long tradition in the human diet. According to the FAO data on primary 257 livestock production in 2017 , about $96 \%$ of the world's fresh milk comes from cows and 258 buffaloes, while the remaining $4.0 \%$ is produced by goats, sheep and camels (FAOStat, 2017). 259 Noteworthy, milk from all ruminant species contains homologous proteins, which share the same structural, functional, and biological properties (Monaci et al., 2006). Cow's milk contains about $3 \mathrm{~g}$ of proteins per $100 \mathrm{~mL}$ and includes at least 25 different proteins classified in two main categories according to their solubility at $\mathrm{pH} 4.6$ and $20^{\circ} \mathrm{C}$ (Fox, 2001); the insoluble protein fraction that precipitates are caseins ( $\alpha$ S1-casein, $\alpha \mathrm{S} 2$-casein, $\beta$-casein, $\mathrm{k}$-casein), while the soluble fraction constitutes the serum characterized by whey proteins ( $\beta$-lactoglobulin, a-lactalbumin, bovine lactoferrin, bovine serum albumin, and immunoglobulins), corresponding to $80 \%$ and $20 \%$, respectively. All the caseins present genetic polymorphisms, which account 
267 for the high heterogeneity of such proteins with several identified variants. The latter are 268 characterized by single amino acid substitution, by deletions of peptides fragments and by 269 occurrence of post-translational modifications, such as glycosylation, phosphorylation, or partial 270 hydrolysis, which may affect their specific allergenicity (Fox, 2001; Wal, 2001) and peptide utility 271 in LC-MS assays. The main allergenic proteins of whey are the globular proteins $\beta$-lactoglobulin 272 and $\alpha$-lactalbumin, which are not phosphorylated and contain intramolecular disulfide bonds 273 that stabilize their structure.

274 Besides the direct consumption of raw milk, a wide range of derived food products can be 275 manufactured from either raw milk or its condensed forms, such as cheese, butter products, 276 cream products, powdered formulations; in addition, casein and whey protein fractions can also 277 be used independently as ingredients in several commodities, including cheese, bakery 278 products and glues. Therefore, the design of robust methods of analysis tailored to detect 279 potential milk contaminations requires the selection of specific markers tracking independently 280 the two main milk fractions, caseins and whey.

281 The critical evaluation of data displayed in Fig. 2, pointed out that milk has not been only the 282 most investigated source of food allergens, but also the allergenic food where the highest 283 consensus was achieved in the selection of signature peptides. The milk proteotypic peptides 284 FFV, YLG and HQG (see Table S2 for peptides full sequences) belong to the aS1-casein (Bos $285 \mathrm{~d}$ 9), which is considered the most abundant protein in milk. They have been validated in many 286 independent studies for targeted analysis, including several kind of matrices, such as liquid 287 matrices (wine, ice cream), bakery products (bread, cookie, muffin), high fat and polyphenol 288 matrices (chocolate), acidic formulation (tomato sauce), high protein matrices (meat products) 
etc. In addition, a few signature peptides were also reported for $\beta$-casein (Bos d 11), $\alpha$ S2-casein

290 (Bos d 10), and k-casein (Bos d 12), in the perspective to monitor two different allergenic 291 proteins tracking for the same ingredient. As for whey proteins, main reliable signature peptides 292 belonged to the $\beta$-lactoglobulin ( $\beta-L G, M W=18.3 \mathrm{kDa}$ ), which is the most abundant protein in 293 whey. This protein belongs to the lipocalin superfamily and is one of the best characterized 294 lipid-binding proteins. It possesses three disulfide bridges and is present in two main variants with punctual mutations. $\beta-$ LG occurs naturally as a mixture of monomers and dimers, but the proportion of monomers increases after heating to $70^{\circ} \mathrm{C}$ (Monaci et al., 2006). TPE, LVL and LSF were highlighted as the most common signature peptides, already validated into incurred matrices. Noteworthy, the LSF peptide corresponding to the protein C-terminal, despite featuring a cysteine residue, has been selected for its robustness. In addition, some peptide 300 markers were proposed also for a-lactalbumin (VGINYWLAHK, FLDDDLTDDIMCVK, 301 DDQNPHSSNICNISCDK, LDQWLCEK, CEVFR), but none of them was validated in either 302 chocolate-based matrix or thermally processed incurred matrices; therefore, they were 303 excluded from the list of candidate markers at the first selection stage. The specificity of all 304 reported milk peptide markers was confirmed, and some of the sequences showed 305 conservation among proteins from other farmed species, still with no specificity issues with 306 other allergenic food ingredients.

307 Eggs are, together with milk the most common allergenic foods affecting European children. 308 Hen's eggs are very common in the human diet as inexpensive source of high quality proteins 309 and they represent a key ingredient in many food products, given its nutritional value and unique 310 functional properties, such as emulsifying, foaming and gelling. Several egg-based formulations 311 have been involved in food manufacturing, such as whole egg, egg white, lysozyme isolate, 
egg yolk, all containing a different degree of allergenic potential (Benedé et al., 2015). The main egg white allergenic proteins are ovomucoid (Gal d 1), ovalbumin (Gal d 2), lysozyme (Gal d 4) and ovotransferrin (Gal d 3), all listed in Table 1, with specific mention to the known posttranslational modifications. Yolk, globally, it is significantly less allergenic than albumen, containing two main allergenic proteins, namely Gal d 5 and Gal d 6, both belonging to the livetins fraction. The latter accounts for about $30 \%$ of the yolk proteins, however, relative abundance of Gal d 5 and Gal d 6, is hard to define. Gal d 5 is the main a-livetin, whereas Gal d 6 (protein YPG 42) derives from major $\beta$-livetins as C-terminal fragment of vitellogenin 1.

Ovomucoid is one of the most important allergen in the egg white, however it was rarely selected as reporter for egg contamination, in MS based methods. Indeed we retrieved information about a single peptide marker (AFNPVCGTDGVTYDNECLLCAHK, Montowska \& Fornal, 2018) that was never validated in either chocolate-based matrix or thermally processed incurred matrices, thus excluded from the list of candidate markers at the first stage of the literature review. Ovalbumin, as most abundant protein in egg white, is the most common protein used as marker forhen's egg contamination. It is a phosphoglycoprotein with a molecular mass of $45 \mathrm{kDa}$ belonging to the serpin superfamily, with an intra-molecular disulfide bond between $\mathrm{C}$ residues in positions 74 and 121 . Noteworthy, besides the most cited peptide GGL, which was monitored in several independent investigations, eight of them including hardto analyze matrices, all the other peptides LTE, ELI and YPI contain amino acids prone to modifications, methionine, asparagine (NG motif) and cysteine, respectively (Fig. 2). In particular, the peptide LTE was alternatively detected either in its native or in the M-oxidized forms depending on the matrix (De Angelis et al., 2017b; Pilolli et al., 2017a; Pilolli et al., 2017b; Pilolli et al., 2018). The peptide ELI contains the dipeptide NG prone to spontaneous asparagine 
deamidation. The peptide YPI contains the cysteine residue in position 121 involved in the disulfide bridge. Alternative ovalbumin signature peptides have been also reported, such as HIA and ISQ all displayed in Fig. 2.

Similarly to milk fractions, different egg-derived formulations used in food manufacturing require specific markers to be selected for each part of the allergenic ingredient that could eventually contaminate food commodities. Thus, in addition to egg white markers, it is important to select specific markers of egg lysozyme, industrially applied as protein isolate for its antimicrobial properties, and egg yolk. Only a limited percentage of the collected studies considered this point. As for direct lysozyme detection, we disclosed three main markers, FES, NTD and GTD, which have been validated at least once into incurred baked products, such as cookies and muffins. The egg yolk has been rarely investigated so far, indeed only six studies were collected detecting specific egg yolk proteins, four of them developing a targeted approach (Planque et al,. 2016; Planque et al., 2017b; New et al., 2018; Planque et al., 2019), and two presenting only the identification of potential markers by HR-MS discovery analysis (Lee \& Kim, 2010; Gavage et al., 2019). Luckily, most of them already tested a wide diversity of food matrices, with different complexity degree, such as cookie, bread, chocolate, salad dressing, spices, ham (see Table S2 for further details), also taking into consideration the ingredient inclusion before food processing. Noteworthy, Gavage et al., 2019 proposed a systematic investigation of potential egg markers (selected for both egg white and egg yolk), in raw and processed eggbased commodities, promoting the use of a dual enzyme digestion protocol, which benefits from the use of the lysyl endopeptidase in addition to trypsin to provide the same site-specific cleavage with higher proteolytic yield. Focusing on the four targeted investigations (Planque et al., 2016; Planque et al., 2017b; New et al., 2018; Planque et al., 2019), we disclosed that none 
of the reported signature peptides traced directly the allergenic protein YGP42, which is the carboxy-terminal portion (284 AAs) cleaved from the primary translation product of vitellogenin1. Indeed, the peptides YLL and ALL both belong to the amine terminal chain of vitellogenin-1, known as lipovitellin-1. Three additional peptides included in the allergenic protein YGP42 were proposed by Gavage et al., 2019, TVI, NVN, ATA, by mean of the dual enzyme digestion protocol, which could be considered for further assessment in the development of targeted investigations.

The sequence specificity control by BLAST proved that none of the reported peptide markers was common to other allergenic ingredients, however some of them (especially lysozyme and vitellogenin-2 peptides) presented conserved sequence in proteins from bacteria and from other animal species, unlikely to occur in food commodities.

Further non-allergenic proteins were also proposed to trace for egg yolk contamination, such as the vitellogenin-2, the apolipoprotein B and the apovitellenin-1.

\subsection{Proteins and peptide markers for legumes: peanut and soybean.}

Peanut and soybean are both members of the Fabaceae or Leguminosae family. Legumes represent $27 \%$ of the primary crop production worldwide, highly diffused in the human diet as excellent sources of proteins, water soluble fibers, numerous micronutrients, and phytochemicals (Smýkal et al., 2015). Peanut is the best characterized legume in regard to its allergenic content, having sixteen proteins, mainly seed storage proteins, classified as allergens with specific isoforms identified and listed in Table 1. As for soybean, the number of characterized allergens is relatively limited, with eight allergens officially registered by the WHO/IUIS Allergen Nomenclature Subcommittee (Allergen Nomenclature, accessed in 
September 2018). Legume allergens can be grouped into a restricted number of families and superfamilies, and the most relevant allergens are seed storage proteins belonging to the cupin and prolamin superfamilies. The cupin superfamily share a conserved $\beta$-barrel structural core domain, which can be single or double; the seed storage proteins $7 \mathrm{~S}$ and $11 \mathrm{~S}$ globulins are both bicupins. The prolamin superfamily includes proteins with conserved cysteine residues at specific positions, sharing a common tridimensional structure with four a-helices stabilized by disulfide bonds. This superfamily includes the $2 \mathrm{~S}$ albumins and non-specific lipid transfer proteins (ns-LTPs). In addition, minor allergens belong to the profilins and Bet $v$ (Betula verrucosa) 1-like superfamilies, which are associated with pollen allergy, the defensins, involved in plant defense against pathogens, and the oleosins, structural proteins of intracellular lipid storage organelles.

Current methods for MS-based peanut detection mainly target Ara h 1 (7S-globulin, vicilin-type), Ara h 2 (2S albumin, conglutin) and Ara h 3 (11S globulin, glycinin) proteins. All peptides reported for these three proteins are highly specific, being conserved only among specific peanut related taxonomies (Arachis ipaensis (130454), Arachis hypogaea (3818), Arachis duranensis (130453)). Ara $\mathrm{h} 1$ is a glycoprotein that makes up $12-16 \%$ of the total protein content and forms stable trimers held by non-covalent interactions (Palladino \& Breiteneder, 2018). Two isoforms has been identified, encoded by two different clones $41 \mathrm{~B}$ (Ara h 1.0101) and P17 (Ara h 1 clone P 17), with a sequence identity higher than $90 \%$. Both proteins have an $\mathrm{N}$-terminal 25 amino acid residue signal peptide and a single glycosylation site. The signal peptide drives the nascent protein to the storage vacuole where both the signal itself and a specific portion of the $\mathrm{N}$-terminal is cleaved-off to yield the mature Ara $\mathrm{h} 1$ found in peanut (Palladino \& Breiteneder, 2018). All the Ara h 1 marker peptides reported so far are shared 
between the two isoforms, and none of them include the glycosylation site (asparagine residue at position 521 of clone 41B and position 516 of clone P17, see Fig. S1 for details). DLA, VLL and GTG are the most frequently selected, already tested in several incurred and hard-to analyze matrices.

Ara $\mathrm{h} 2$ represents the $5.9-9.2 \%$ of the total protein content and can be expressed from different genes into two isoforms Ara h 2.01, and Ara h 2.02, the latter differing for the insertion of a 12 amino acid motif at position 75 in comparison to the Ara $\mathrm{h}$ 2.01. In addition, the Allergome database further distinguishes the two isoforms in four variants (Ara h 2.0101, Ara h 2.0102, Ara $\mathrm{h}$ 2.0201, Ara $\mathrm{h}$ 2.0202), which, besides the signal sequence, differ for a single amino acid mismatch (E vs $\mathrm{D}$ ) close to the C-terminal portion of the full sequence (position 163 in the Ara h 2.0201 sequence). Furthermore, Ara h 2 undergoes proteolytic processing by peanut proteases resulting in the removal of the C-terminal dipeptide RY. Consequently, the Ara h 2 can be found as a mixture of all the four variants as well as their slightly truncated forms. Four intra-molecular disulfide bonds hold the tridimensional structure of the Ara h 2 and three proline residues are present in their hydroxylated form (see Fig. S2). Interestingly, none of the markers reported in Fig. 3 for Ara h 2 contain the 4-hydroxylproline residues, however all of them contain cysteine residues directly involved in the formation of the four disulfide bridges. In addition, the CMC also contained two methionine residues, susceptible to oxidation. The first three peptides, namely CCN, NLP and CMC are shared among all the isoforms (see Fig. S2), whereas the peptide CDL includes the position affected by single amino acid substitution, thus both the variants CDLEVESGGR (reported peptide) and CDLDVESGGR (potential alternative sequence) can be found in nature with unpredictable proportions. 
425 Ara $\mathrm{h} 3$ is a glycinin-like protein (11S) with a molecular mass of $60 \mathrm{kDa}$ for the monomer and occurs in peanuts as hexamer of $360 \mathrm{kDa}$ (Palladino \& Breiteneder, 2018). The monomer is 427 post-translationally cleaved in $43 \mathrm{kDa}$ acidic and $28 \mathrm{kDa}$ basic subunits, covalently linked by a 428 single disulphide bond. Ara h 3 and Ara h 4, initially considered as different allergenic proteins, have been identified as variants of the same gene, thus they were renamed as isoforms Ara $h$ 3.01 and Ara h 3.02. These are the only two isoforms officially listed by the WHO/IUIS Allergen Nomenclature Subcommittee, whereas further Uniprot entries are classified as Ara h 3 in the Allergome database. A genomic clone encoding Ara h 3 (AF10854) (Viquez et al., 2004) was identified as having four exons. The deduced protein (538 AA in length) showed 93\% and 91\% identity with the Ara h 3 (isoform Ara h 3.01) and Ara h 4 (isoform Ara h 3.02) (Palladino \& Breiteneder, 2018), respectively. Furthermore, an additional isoform named iso-Ara h 3 was reported as sharing only $70-85 \%$ of identity with previously cited sequences (Boldt et al., 2005). Several peptide markers tracing for Ara h 3 protein were reported so far (see Fig. 3), however, surprisingly for this particular case, the criterion of sequence sharing among known isoforms has not been valued properly in the current literature (see Fig. S3). Indeed, some of proposed markers were not conserved among protein variants, and according to common sense, they should have been excluded, for their limited representativeness. For example, the peptide SPD, which is cited in 13 investigations, is encrypted only in the Ara h 3.01 isoform (and in the genomic clone). Quite surprising was also the selection of the peptide TANEELNLLILR in two very recent papers (Planque et al., 2017a; Planque et al., 2017b), which was not encoded by the officially recognized isoforms Ara h 3.01 and Ara h 3.02, but only by the Ara $\mathrm{h} 3$ genomic clone. Noteworthy, the peptide LNA is the only marker fully conserved across the isoforms 
447 while, the peptides RPF, QQP are common only to the two main isoforms Ara $\mathrm{h} 3.01$ and Ara $448 \quad$ h 3.02.

As previously stated, soybean is another edible legume belonging to the Fabaceae family, widely consumed worldwide for its high protein content (approximately 38-40 \%). It finds also wide applicability as ingredient in meat/poultry products, bakery and pastry products, dairy products, and edible spreads, as well as additive for a variety of pharmaceutical and industrial applications (Verma et al., 2013). As such, the number of occurring soy based formulations is very high, ranging from raw to highly processed and/or hydrolyzed commodities and this makes the absolute quantification of soy contamination in complex matrices quite challenging.

The WHO/IUIS recognized eight soybean proteins as official allergens, including hydrophobic protein (Gly m 1), defensin (Gly m 2), soy profilin (Gly m 3), pathogenesis-related protein (Gly m 4), $\beta$-conglycinin (Gly m 5, vicilin, 7 S globulin), glycinin (Gly m 6, legumin, $11 \mathrm{~S}$ globulin), seed biotinylated proteins (Gly $\mathrm{m} 7$ ) and the $2 \mathrm{~S}$ albumin protein group (Gly $\mathrm{m} 8$ ). The major storage proteins, $\beta$-conglycinin and glycinin, both belonging to the cupin superfamily, represent alone the $70-80 \%$ of the total seed globulin fraction (De Angelis et al., 2017a). $\beta$-Conglycinin is $7 \mathrm{~S}$ globulin glycoprotein containing $5 \%$ of carbohydrate moieties and occur as trimers with molecular masses of approximately $180 \mathrm{kDa}$. Therefore, the Gly $\mathrm{m} 5$ allergen name refers to the complex of three $\beta$-conglycinin subunits that were not characterized at the time name was assigned (Pomés et al., 2018). The three subunits were first described by Holzhauser et al. (2009) labeled as $\alpha(67 \mathrm{kDa}), \alpha^{\prime}(71 \mathrm{kDa})$ and $\beta(50 \mathrm{kDa})$, and were assessed to combine at different ratios to form the multimeric complexes. The $\alpha$ and $\alpha^{\prime}$ subunits are approximately $82 \%$ identical, whereas the $\beta$-subunit is only $76 \%$ identical to the two a subunits. The individual 
subunits were named as isoallergens Gly m 5.01, Gly m 5.02 and Gly m 5.03 in 2009, with

470 minor variants (e.g. Gly m 5.0301 and Gly m 5.0302 presenting two amino acid mismatches

471 L/F at positions 16 and 198). Interestingly, the in-silico simulation of tryptic digestion showed

472 that the isoallergens Gly m 5.01, Gly m 5.02 and Gly m 5.03 do not share any tryptic peptide

473 with minimum length of $7 \mathrm{AA}$, which could be selected as a common marker for the $\beta$ -

474 conglycinin subunits. This issue makes the absolute quantification of soybean allergen by 475 synthetic peptide analysis quite challenging since the required conversion factors should base 476 on the knowledge of the specific combination of $\alpha, \alpha^{\prime}$ and $\beta$-subunits occurring in the sample 477 under investigation. As expected by in-silico prediction, none of the reported peptide markers 478 for Gly m 5 displayed in Fig. 3 were conserved among the three isoallergens (see Fig. S4). 479 Interestingly, an alternative solution, in this case, would be to select unique markers for each 480 subunit in order to disclosethe specific combination of $\alpha, \alpha^{\prime}$ and $\beta$-monomers within the trimeric 481 complex. In this frame, the peptide LIT would uniquely trace for Gly $m 5.01$, the peptides $Q Q Q$

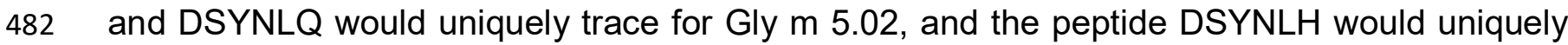
483 trace for Gly m 5.03 (noteworthy, the latter is conserved between the two variants Gly m 5.0301 484 and Gly $m$ 5.0302). Attention should be paid to the peptide AIV, even if theoretically unique for

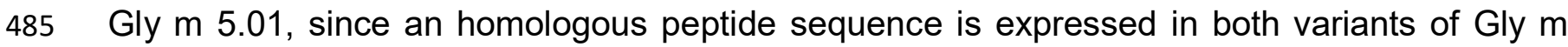
4865.03 , with a single amino acid substitution L/I at position P19, which could not be discriminated 487 by SRM acquisition. None of the aforementioned peptides contain amino acid residues with 488 naturalpost-translational modification.

489 In most soybean varieties, the glycinin accounts for over $50 \%$ of seed storage proteins 490 representing the predominant protein fraction (De Angelis et al., 2017a). Glycinin has a complex 491 hexameric structure with a molecular weight ranging between 320 to $360 \mathrm{kDa}$. At least five 
genes encode the monomeric subunits (Nielsen et al., 1989) and the Gly $\mathrm{m} 6$ allergen can be an arrangement of these five proteins, which have individual IgE binding properties (Holzhauser et al., 2009). Each monomer consists of two specific polypeptide chains, one acidic (40 kDa) (A) and one basic (20 kDa) (B), linked together by disulfide bonds. Each monomer can be one of five subunits, namely glycinin $G 1\left(A_{1 a} B_{1 b}\right)$, glycinin $G 2\left(A_{2} B_{1 a}\right)$, glycinin $G 3\left(A_{1 b} B_{1 a}\right)$, glycinin G4 $\left(A_{5} A_{4} B_{3}\right)$ and glycinin $\left(A_{3} B_{4}\right)$ (Wang et al., 2014), being renamed as five isoallergens Gly $m$ 6.0101, Gly m 6.0201, Gly m 6.0301, Gly m 6.0401 and Gly m 6.0501, respectively, in 2009. Similarly to what was already discussed for the quantification of Gly $\mathrm{m} 5$ allergen, the unpredictable composition of the Gly $\mathrm{m} 6$ hexameric complex makes general conversion factors a hard task to achieve. The peptide marker selection carried out so far in current literature completely neglected the different sequence expression in known isoallergens. Indeed, the most frequently used markers, VFD, VLI, and EAF, are expressed uniquely in Gly m 6.0101, whereas the peptide SQS, cited in 8 independent investigations, is conserved across the three isoforms Gly m 6.0101, Gly m 6.0201, Gly m 6.0301, and the peptide IST (cited in 7 independent investigations) is common to the isoforms Gly m 6.0401 and Gly m 6.0501 (see Fig. S5).

\subsection{Proteins and peptide markers for tree nuts: hazelnut and almond}

Hazelnut and almond allergens were selected in this project as most relevant members of the tree nut category according to the European legislation. Similar to peanut and soybean, the main proteins involved in tree nut allergy belong to cupin (legumins-11S globulin and vicilin-7S globulin) and prolamin (conglutin-2S albumin and ns-LTPs) superfamilies. Several hazelnut allergens have been identified and are already partly applied in component resolved diagnosis (Geiselhart et al., 2018). However, only partial information have been collected so far about the 
occurrence of potential allergen isoforms and their complete sequencing, even if their existence

515 is likely, given the high genetic diversity of plant organisms. Even the limited information 516 available for almond allergens, the provided following discussion about the peptide marker 517 selection was driven to the best of the current knowledge for these two allergens, and relevant 518 homologous plant proteins.

WHO/IUIS database included eight hazelnut allergens all listed in Table 1. According to the EuroPrevall population-based survey, including allergic subjects from twelve European cities, the predominance of specific hazelnut allergens is correlated to the geographical area (Pastorello et al., 2002), as well as to the age of the sensitized individuals (Verweij et al., 2012). In the Mediterranean areas, hazelnut allergy is mainly linked to Cor a 8, Cor a 14, Cor a 9, Cor a 11 (Schocker et al., 2004; Blanc et al., 2015). Cor a 8 is a nsLTP type 1, as mature protein, consisting of a unique polypeptide chain of 92 amino acid residues with eight strictly conserved cysteines forming four intramolecular disulfide bridges. Cor a 14 (2S albumin) is a heterodimeric protein with characteristic structural features, including four $\alpha$-helices and eight cysteine residues engaged in four disulfide bridges (Pfeifer et al., 2015). The precursor protein is posttranslationally cleaved into a large and a small subunits linked by disulfide bonds. The Nterminal glutamine shows the cyclization to pyroglutamic acid and the small subunit is variably truncated at the C-terminal, leading to a high micro-heterogeneity (Pfeifer et al., 2015). Cor a 9, as $11 \mathrm{~S}$ legumin, exhibits some homology with other tree nut allergens, such as cashew Ana o 2, peanut Ara h 3 and the soybean glycinin (Gly m 6). The monomer consists of two polypeptide chains (acidic and basic chains), cleaved post-translationally by site specific endopeptidases, and linked together by a single intermolecular disulfide bond. The WHO/IUIS recorded a single isoform of the Cor a 9 protein corresponding to the Uniprot accession 
Q8W1C2 and labelled as Cor a 9.0101, first identified in 2002 as IgE-binding protein by 2DWestern blotting, using sera of hazelnut allergic patients (Beyer et al., 2002). In 2013, a new isoform of the same protein, with a 514 AA full-length sequence, was registered (Uniprot accession AOAOAOP7E3) sharing 96.5\% homology (Grishina et al., 2013). This isoform has been added to the Allergome database with the general label of Cor a 9. Additionally, at least another $55 \mathrm{kDa}$ protein, with high IgE-reactivity only in the alkaline chain (20.7 kDa), has been identified by Nitride et al. (2013). In this investigation, shotgun proteomics allowed de novo sequencing of six peptides of the basic chain and their assignment to $11 \mathrm{~S}$ protein isoform sharing high homology with $11 \mathrm{~S}$ globulin-like proteins from several plant organisms, including the canonical hazelnut one. Starting from this background, we reviewed the current literature tracing the Cor a 9 selected markers. The peptide WLQ should be excluded by any further discussion since conserved sequence among different tree nut species (hazelnut, pistachio, pecan, and walnut). Besides this, we assessed that all the proposed signature peptides shared $100 \%$ identity between the official Cor a 9.0101 (Q8W1C2) sequence and its registered isoform A0A0A0P7E3 (see Fig. S6). However, considering the further potential isoform only partially sequenced by Nitride et al. (2013), three out of the seven reported peptides might be excluded, as non-conserved regions and, noteworthy, this exclusion would involve two of the most cited peptides INT and ALP. Therefore, a wider characterization of most common isoform occurring by natural genetic diversity is urgently needed. In addition, the peptide VQV contains the NG motif, which makes the asparagine residues highly susceptible to deamidation.

Cor a 11 is a 7 globulin like protein, featuring a trimeric structure of MW about 150/190kDa with subunits of about $50 \mathrm{kDa}$. The WHO/IUIS lists a single isoform labelled as Cor a 11.0101, corresponding to the Uniprot entry Q8S4P9, which includes a single glycosylation site occurring 
at the asparagine residue. Three peptide markers have been reported for this protein, namely LLS, AFS, and ELA, and none of them includes amino acid residues prone to modifications.

As for almond, six identified almond allergens, Pru du 3 (ns-LTP), Pru du 4 (profilin), Pru du 5 (60 S ribosomal protein), and Pru du 6 (legumin), are included in the WHO-IUIS allergen list. The specificity in the analytical detection of this allergen is particularly challenging due to both a limited availability of full-length sequences in official database and due to the high homology of almond proteins (taxonomy Prunus dulcis) within the Prunus taxonomy genus, mainly Prunus persica (peach) (Inman et al., 2018). For example, the almond allergen Pru du 3.0101 displays 99\% amino acid sequence identity to a nsLTP from peach (UniProtKB M5W0S9, not listed in the IUIS) and 57\% to two other peach nsLTP isoforms, Pru p 3.0101 and Pru p 3. 0102 . Two native isoforms have been identified for the almond profilin (Pru du 4), but its relevance is mainly restricted to pollen-associated almond allergy. Pru du 5 has been identified as an $11.4 \mathrm{kDa} 60 \mathrm{~S}$ ribosomal protein involved in protein biosynthesis (Abolhassani \& Roux, 2009); nevertheless, the clinical relevance of this allergen is unknown and requires further research. Finally, Pru du 6, a legumin-like protein, also called amandin, is the first and best biophysically characterized allergen in almond to date (Geiselhart et al., 2018). Two cDNA clones encoding almond legumins named prunin-1 (61.0 kDa) and prunin-2 (55.9 kDa) have been isolated, both included in the WHO/IUIS database as Pru du 6.0101 and Pru du 6.0201. By in-silico simulation of the enzymatic digestion with trypsin specific cleavage, it was assessed that no tryptic peptide with minimum length of 7 AA presents full identity between the two isoforms Pru du 6.0101 and Pru du 6.0201 (see Fig. S7). In addition, Allergome database also includes two variants of Pru du 6.0101 and Pru du 6.0201, registered with the Uniprot entries Q43607 and Q43608, respectively, which share $99 \%$ identity with the relevant official allergen isoform, featuring only 
583 few amino acid substitutions (see Fig. S7). In Fig. 3, we presented the signature peptides reported so far for almond detection by SRM analysis all belonging to the Pru du 6 protein, either to the Pru du 6.0101 or to the Pru du 6.0201 isoallergens. Noteworthy, most of the selected peptides highlighted with asterisks presented specificity issues, since the BLAST search against non-redundant protein database showed $100 \%$ sequence identity with homologous proteins from Prunus persica, Prunus mume or Prunus avium, (see Fig. S8 and S9). In light of this, we kept in the list reported in Fig. 3 also the two markers QQG both VQV, even if they were not validated in incurred or chocolate based matrices, as only candidates, together with TDE, which feature uniqueness for Prunus dulcis species. Interestingly, none of the reported peptides included cysteine residues involved in the disulfide bridges, whereas both the unique peptides VQV and TDE contain the motif NG that make them susceptible to spontaneous deamidation. In addition, the sequences VQVVNENGDPILDDDEVR and ALPDEVLQNAFR, belonging to the Pru du 6.0201 isoform were not conserved in the alternative allergen variant registered as Q43608 in Uniprot database, both presenting single amino acid substitutions (D/N and N/T, respectively) and the peptide variant VQVVNENGDPILNDEVR is shared with Prunus persica (see sequence alignment in Fig. S9).

\subsection{List of candidate markers agreed by ThRAll partners}

The thorough discussion presented in the previous section allowed the selection of a restricted list of candidate signature peptides that can be fruitfully employed for allergen detection in highly complex and processed foods with a high-confidence on identification accuracy. This list representing the consensus table of the consortium is reported in Table 2 and will be further validated for its reliability in the model matrices selected within the ThRAll project by discovery 
experiments by untargeted HR-MS/MS analysis. As already mentioned, the preliminary marker selection here performed by means of the critical evaluation of current literature represents only the first step of the dual approach devised for the ThRAll project. The experimental validation of the candidate markers by MS/MS analysis is a mandatory step in method development because several empirical features, such as matrix composition, extraction/digestion conditions, and instrumental parameters might affect both the specificity and sensitivity of the final analytical method. Interferences in the chromatographic analysis from complex food background and information about processing effects on the ingredient itself or finished food products should be traced to avoid false-negative and false-positives. Such information cannot be disclosed merely by any in-silico based approach.

The Table 2 was populated with all the information about sequence sharing among isoforms/variants per each discussed peptide.

As for the protein homology check among different taxonomies carried out on plant-derived allergens, we concluded that according to the current knowledge of full-length protein sequences, none of the signature peptides selected for plant-derived allergens (Table 2) is affected by homology issues. To the best of the current knowledge, the refined list of peptides provided very high detection specificity. For sake of clarity in Table S3, we reported a short list of peptide markers identified that might experience this kind of interference from other homologous proteins, disclosing both the targeted and the interfering precursor ions, as well as the shared transitions.

As for Pru du 6 peptides, with high sequence identity with homologous proteins from Prunus persica, Prunus mume and Prunus avium, only two peptide markers were kept, including the 
627 unique peptide TDE, even if encrypting the NG motif, since it can still be useful for confirmative 628 purposes.

629 Finally, in Table 2 we also collected information about the reported precursor ions and the 630 transitions monitored. Both the preferential ionization state of the target peptide and its typical 631 fragmentation pattern depend not only on the specific amino acid sequence, but also on 632 instrumental parameters such as the ionization source, the MS platform, and the activation 633 mode; therefore, after proper marker selection, the ionization and fragmentation features need 634 to be assessed on the specific MS platform involved in the study. From a general point of view, 635 we highlighted that most of the selected signature peptides were detected as double charged 636 ions, which indeed are very stable and reproducible both in their ionization yield and in the 637 fragmentation pattern, whereas an heterogeneous scenario was disclosed as for transitions 638 selection. Either two or three transitions per peptide were acquired, in some cases the two 639 monitored fragments are simply two different ionization states of the same transition $\left(\mathrm{yn}^{+}\right.$and $\left.640 \mathrm{yn}^{++}\right)$. This behavior is typical of proline containing peptides that upon collisional induced 641 fragmentation preferentially break the peptide bond at the $\mathrm{N}$-terminal proline site, releasing the 642 same transition as both single and double charged ions (Ma \& Johnson, 2012). This transition 643 is usually very sensitive, but the ratio $\left(\mathrm{y}_{\mathrm{n}}+/ \mathrm{yn}^{++}\right)$between the two ions is not fixed, and may 644 change upon different instrumental conditions. Additionally, retrieving the SRM instrumental 645 details for the reported papers we also disclosed that in some investigations quite small 646 fragments have been selected, namely $\mathrm{y}_{1}{ }^{+}, \mathrm{b}_{2}{ }^{+}, \mathrm{a}_{2}{ }^{+}$, notwithstanding their low selectivity and 647 susceptibility to interference from the background. 
648 In light of the harmonization of detection method, and given the heterogeneous picture retrieved 649 for instrumental set up, we will select at least three transitions for each marker, preferably 650 belonging to the $y_{n}$ and $b_{n}$ series. Indeed, $y$ - and $b$ - ion series together would allow read out of 651 the full peptide sequence from the MS/MS spectrum in the two directions starting from the C652 and the N-terminus, respectively (Ma \& Johnson, 2012); in addition, the two series together 653 would account for most of the MS/MS spectrum ion intensity in both HCD and CID 654 fragmentations (Michalski et al., 2012), with very high stability of the y-type transitions. 655 Noteworthy, the monitored fragments should actually correspond to different transitions with a 656 minimum fragment length of 3 amino acids, given the minimum length for peptide markers of 7 657 amino acids, in order to guarantee the maximum specificity and sequence coverage to the final 658 developed method.

659 Future development of this work, will be the experimental validation of the reported preliminary 660 list of candidate markers. In particular, discovery high resolution MS/MS analysis will be carried 661 out directly on the two matrices, namely chocolate bar and broth powder as model hard-to 662 analyze food matrices, produced in a food pilot plant and incurred at the high contamination 663 level. The experimental list of identified peptides belonging to the allergenic ingredients will be 664 compared with the literature based selection either confirming or proposing new options for the 665 SRM set up.

\section{Conclusions}

667 In this work we described the results of our comprehensive evaluation of the existing literature 668 on food allergen detection by MS based methods, concerning the selection of peptide markers. 669 We collected all information about the six allergens selected for the ThRAll project, namely 


\section{Ethical approval}

689 690 of the Authors.

\section{Acknowledgements}

cow's milk, hen's egg, peanut, soybean, hazelnut and almond. The selected peptides were critically discussed according to specific considerations and recommended criteria for marker selection that we promote in perspective harmonization of analytical methods development. The in-depth analysis of current knowledge allowed the selection of a restricted list of candidate signature peptides, already validated in several independent analyses, which could be monitored with high confidence. This preliminary list will be validated in the two model matrices selected within the ThRAll project, in a separate investigation for its final confirmation by specific discovery experiments with untargeted HR-MS/MS analysis.

This project has received financial support from the European Food Safety Authority (EFSA), Grant GP/EFSA/AFSCO/2017/03 and the UK Food Standard Agency (FSA), Grant FS101206 Development of Quality Control Materials for Food Allergen Analysis The present paper, however, is under the sole responsibility of the authors. The positions and opinions presented in this article are those of the authors alone and do not necessarily represent the views/any official position or scientific works of EFSA. To find out more about EFSA guidance documents and other scientific outputs of EFSA, please consult its website at: http://www.efsa.europa.eu.

The authors are thankful to Dr. Michal Walker (from LGC) for the fruitful exchanges on this

This article does not contain any studies with human participants or animals performed by any 
691 Competing interests

692 The Authors declare they have no competing interest. 
694 Figure 1. Analytical workflow describing step-by-step the literature review and the critical 695 evaluation of the proposed peptide markers in order to compile a final list of highly reliable 696 signature peptides to be tested for the ThRAll project.

697 Figure 2. Citation overview of the peptides markers used for milk and egg allergens, which 698 where validated at least once in hard-to-analyze matrices, highlighting the kind of investigation 699 (targeted approach or discovery only approach) and the presence of amino acids prone to 700 modifications. *peptide without $C, M, E, N$, or $Q$ amino acid.

701 Figure 3. Citation overview of the peptides markers used for peanut, soybean, hazelnut and 702 almond, which where validated at least once in hard-to-analyze matrices, highlighting the kind 703 of investigation (targeted approach or discovery only approach) and the presence of amino 704 acids prone to modifications. *peptide without C, M, E, N, or Q amino acid. Table 1. Summary of the food allergens proteins recorded for the six allergen under investigations. Acronyms: PTM, post-translational modifications; IUIS, International Union of Immunological Societies. *information gathered from Uniprot Database 708 (https://www.uniprot.org/, Accessed on September 19th 2018).

709 Table 2. Preliminary list of signature peptides selected by the Consortium according to the analytical workflow presented in Figure 1, which have been monitored in targeted investigations with relevant information on allergens isoforms/variants, peptide specificity, and acquisition 712 related technical details (MS platform, precursor ion and selected transitions). The presence of 713 amino acid residues prone to modification was highlighted with a different font (bold and 714 underlined). The transition selected as quantifier ion (when specified) was marked with an 
715 asterisk. Acronyms: QqQ, triple quadrupole; IT, ion trap; QToF, quadrupole time-of flight; Q716 Orbitrap, quadrupole-Orbitrap, LIT, linear ion trap.

717 
719 Abolhassani, M., \& Roux, K. H. (2009). cDNA cloning, expression and characterization of an 720 allergenic 60s ribosomal protein of almond (Prunus dulcis). Iranian Journal of Allergy, Asthma 721 and Immunology, 8, 77-84. https://doi.org/08.02/ijaai.7784

722 Allergen Nomenclature, WHO/IUIS Allergen Nomenclature Sub-Committee. (2018). 723 http://www.allergen.org/ Accessed in July-September 2018.

724 Allergen Peptide Browser. (2018). https://www.allergenpeptidebrowser.org/ Accessed July 7252018.

726 Allergome. (2018). https://www.allergome.org/ Accessed July-September 2018.

727 Ansari, P., Stoppacher, N., Rudolf, J., Schuhmacher, R., \& Baumgartner, S. (2011). Selection 728 of possible marker peptides for the detection of major ruminant milk proteins in food by liquid 729 chromatography-tandem mass spectrometry. Analytical and Bioanalytical Chemistry, 399, 730 1105-1115 https://doi.org/10.1007/s00216-010-4422-0.

731 Ansari, P., Stoppacher, N., \& Baumgartner, S. (2012). Marker peptide selection for the 732 determination of hazelnut by LC-MS/MS and occurrence in other nuts Analytical and 733 Bioanalytical Chemistry, 402, 2607-2615. https://doi.org/10.1007/s00216-011-5218-6.

734 Azarnia, S., Boye, J. I., Mongeon, V., \& Sabik, H. (2013). Detection of ovalbumin in egg white, 735 whole egg and incurred pasta using LC-ESI-MS/MS and ELISA. Food Research International, 736 52, 526-534. https://doi.org/10.1016/j.foodres.2013.02.039.

737 Benedé, S., López-Expósito, I., Molina, E., \& López-Fandiño, R. (2015). Egg proteins as 738 allergens and the effects of the food matrix and processing. Food and Function, 6, 694-713. 739 https://doi.org/10.1039/C4FO01104J.

740 Beyer,K., Grishina, G., Bardina, L., Grishin, A., Sampson, H., A. (2002). Identification of an 11S 741 globulin as a major hazelnut food allergen in hazelnut induced systemic reaction. Journal of 742 Allergy and Clinical Immunology, 110, 517-523. https://doi.org/10.1067/mai.2002.127434.

743 Bignardi, C., Elviri, L., Penna, A., Careri, M., \& Mangia, A. (2010). Particle-packed column 744 versus silica-based monolithic column for liquid chromatography-electrospray-linear ion trap- 
tandem mass spectrometry multiallergen trace analysis in foods. Journal of Chromatography A, 1217, 7579-7585. https://doi.org/10.1016/j.chroma.2010.10.037.

Bignardi, C., Mattarozzi, M., Penna, A., Sidoli, S., Elviri, L., Careri, M., \& Mangia, A. (2013). A Rapid Size-Exclusion Solid-Phase Extraction Step for Enhanced Sensitivity in Multi-Allergen Determination in Dark Chocolate and Biscuits by Liquid Chromatography-Tandem Mass Spectrometry. Food Analytical Methods, 6, 1144-1152. https://doi.org/10.1007/s12161-0129521-4

Blanc, F., Bernard, H., Ah-Leung, S., Przybylski-Nicaise, L., Stahl Skov, P., Purohit, A., de Blay, F., Ballmer-Weber, B., Fritsche, P., Fernandez Rivas, M., Reig, I., Sinaniotis, A., Vassilopoulou, E., Hoffmann-Sommergruber, K., Vieths, S., Rigby, N., Mills, E. N. C., \& Adel-Patient, K. (2015). Further studies on the biological activity of hazelnut allergens. Clinical and Translational Allergy, 5, 26. https://doi.org/10.1186/s13601-015-0066-7.

Boldt, A., Fortunato, D., Conti, A., Petersen, A., Ballmer-Weber, B., Lepp, U., Reese, G., \& Becker, W. M. (2005). Analysis of the composition of an immunoglobulin $E$ reactive high molecular weight protein complex of peanut extract containing Ara $h 1$ and Ara $h$ 3/4. Proteomics, 5, 675-686. https://doi.org/10.1002/pmic.200401150.

Boo, C. C., Parker, C. H., \& Jackson, L. S. (2018). A Targeted LC-MS/MS Method for the Simultaneous Detection and Quantitation of Egg, Milk, and Peanut Allergens in Sugar Cookies. Journal of AOAC International, 101, 108-117. https://doi.org/10.5740/jaoacint.17-0400.

Bucchini, L., Guzzon, A., Poms, R., Senyuva, H. (2016). Analysis and critical comparison of food allergen recalls from the European Union, USA, Canada, Hong Kong, Australia and New Zealand. Food Additives and Contaminants: Part A, 33, 760-771. https://doi.org/10.1080/19440049.2016.1169444.

Careri, M., Costa, A., Elviri, L., Lagos, J. B., Mangia, A., Terenghi, M., Cereti, A., \& Garoffo, L. P. (2007). Use of specific peptide biomarkers for quantitative confirmation of hidden allergenic peanut proteins Ara h 2 and Ara h 3/4 for food control by liquid chromatography-tandem mass spectrometry. Analytical and Bioanalytical Chemistry, 389, 1901-1907. https://doi.org/10.1007/s00216-007-1595-2. 
Careri, M., Elviri, L., Maffini, M., Mangia, A., Mucchino, C., \& Terenghi, M. (2008). Determination of peanut allergens in cereal-chocolate-based snacks: metal-tag inductively coupled plasma mass spectrometry immunoassay versus liquid chromatography/electrospray ionization tandem mass spectrometry. Rapid Communications in Mass Spectrometry, 22, 807-811. https://doi.org/10.1002/rcm.3427.

Chassaigne, H., Nørgaard, J. V., \& van Hengel, A. J. (2007). Proteomics-Based Approach To Detect and Identify Major Allergens in Processed Peanuts by Capillary LC-Q-TOF (MS/MS). Journal of Agricultural and Food Chemistry, 55, 4461-4473. https://doi.org/10.1021/jf063630e.

Chen, S., Yang, C.T., Downs, M. L. (2019). Detection of Six Commercially Processed Soy Ingredients in an Incurred Food Matrix Using Parallel Reaction Monitoring. Journal of Proteome Research, 18, 995-1005. https://pubs.acs.org/doi/10.1021/acs.jproteome.8b00689.

Costa, J., Ansari, P., Mafra, I., Oliveira, M. B., \& Baumgartner, S. (2014). Assessing hazelnut allergens by protein- and DNA-based approaches: LC-MS/MS, ELISA and real-time PCR. Analytical and Bioanalytical Chemistry, 406, 2581-2590. https://doi.org/10.1007/s00216-0147679-x.

Croote, D., \& Quake, S. R. (2016). Food allergen detection by mass spectrometry: the role of systems biology. NPJ Systems Biology Applications, 2, 16022. https://doi.org/10.1038/npjsba.2016.22.

Cryar, A., Pritchard, C., Burkitt, W., Walker, M., O'Connor, G., Burns, D. T., \& Quaglia, M. (2013). Towards absolute quantification of allergenic proteins in food--lysozyme in wine as a model system for metrologically traceable mass spectrometric methods and certified reference materials. Journal of AOAC International, 96, 1350-1361. https://doi.org/10.5740/jaoacint.12438.

De Angelis, E., Pilolli, R., Bavaro, S. L., \& Monaci, L. (2017a). Insight into the gastro-duodenal digestion resistance of soybean proteins and potential implications for residual immunogenicity. Food and Function, 8, 1599-1610. https://doi.org/10.1039/c6fo01788f.

De Angelis, E., Pilolli, R., \& Monaci, L. (2017b). Coupling SPE on-line pre-enrichment with HPLC and MS/MS for the sensitive detection of multiple allergens in wine. Food Control, 73, 814-820. https://doi.org/10.1016/j.foodcont.2016.09.031. 
Downs, M. L., \& Johnson, P. (2018). Target selection strategies for LC-MS/MS food allergen methods. Journal of AOAC International, 101, 146-151. https://doi.org/10.5740/jaoacint.170404.

European Commission, COMMISSION NOTICE of 13.7.2017 relating to the provision of information on substances or products causing allergies or intolerances as listed in Annex II of Regulation (EU) No 1169/2011 on the provision of food information to consumers.

Eyers, C. E., Lawless, C., Wedge, D. C., Lau, K. W., Gaskell, S. J., \& Hubbard, S. J. (2011). CONSeQuence: prediction of reference peptides for absolute quantitative proteomics using consensus machine learning approaches. Molecular and Cellular Proteomics, 10, M110.003384. https://doi.org/10.1074/mcp.M110.003384.

FAOSTAT (2017), Food and Agriculture Organization of the United Nations, http://www.fao.org/faostat/en/\#data/QL, accessed 9 January 2019.

Figeys, D., van Oostveen, I., Ducret, A., \& Aebersold, R. (1996). Protein identification by capillary zone electrophoresis/microelectrospray ionization-tandem mass spectrometry at the subfemtomole level. Analytical Chemistry, 68, 1822-1828. https://doi.org/10.1021/ac960191h.

Fox, P. (2001). Milk proteins as food ingredients. International Journal of Dairy Technology, 54, 41-55. https://doi.org/10.1046/j.1471-0307.2001.00014.x.

Gavage, M., Van Vlierberghe, K., Van Poucke, C., De Loose, M., Gevaert, K., Dieu, M., Renard, P., Arnould, D. H., \& Gillard, N. (2019). Selection of egg peptide biomarkers in processed food products by high resolution mass spectrometry. Journal of Chromatography A, 1584, 115-125. https://doi.org/10.1016/j.chroma.2018.11.036.

Geiselhart, S., Hoffmann-Sommergruber, K., \& Bublin, M. (2018). Tree nut allergens. Molecular Immunology, 100, 71-81. https://doi.org/10.1016/j.molimm.2018.03.011.

Gomaa, A., \& Boye, J. (2015). Simultaneous detection of multi-allergens in an incurred food matrix using ELISA, multiplex flow cytometry and liquid chromatography mass spectrometry (LC-MS). Food Chemistry, 175, 585-592. https://doi.org/10.1016/j.foodchem.2014.12.017.

Grishina, G., Beyer, K., Bardina, L., Sampson, H. H. (2013). Isoform of a Major hazelnut food allergen Cor a 9 (11S Globulin). EMBL/GenBank/DDBJ Databases. 
Groves, K., Cryar, A., Walker, M., \& Quaglia, M. (2018). Assessment of Recovery of Milk Protein Allergens from Processed Food for Mass Spectrometry Quantification. Journal of AOAC International, 101, 152-161. https://doi.org/10.5740/jaoacint.17-0214.

Gu, S., Chen, N., Zhou, Y., Zhao, C., Zhan, L., Qu, L., Cao, C., Han, L., Deng, X., Ding, T., Song, C., \& Ding, Y. (2018). A rapid solid-phase extraction combined with liquid chromatography-tandem mass spectrometry for simultaneous screening of multiple allergens in chocolates. Food Control, 84, 89-96. https://doi.org/10.1016/j.foodcont.2017.07.033.

Heick, J., Fischer, M., Kerbach, S., Tamm, U., \& Popping, B. (2011a). Application of a liquid chromatography tandem mass spectrometry method for the simultaneous detection of seven allergenic foods in flour and bread and comparison of the method with commercially available ELISA test kits. Journal of AOAC International, 94, 1060-1068.

Heick, J., Fischer, M., \& Pöpping, B. (2011b). First screening method for the simultaneous detection of seven allergens by liquid chromatography mass spectrometry. Journal of Chromatography A, 1218, 938-943. https://doi.org/10.1016/j.chroma.2010.12.067.

Hoffmann, B., Münch, S., Schwägele, F., Neusüß, C., Jira, W. (2017). A sensitive HPLCMS/MS screening method for the simultaneous detection of lupine, pea, and soy proteins in meat products. Food Control, 71, 200-209. https://doi.org/10.1016/j.foodcont.2016.06.021.

Holzhauser, T., Wackermann, O., Ballmer-Weber, B., Bindslev-Jensen, C., Scibilia, J., PeronoGaroffo, L., Utsumi, S., Poulsen, L. K., \& Vieths, S. (2009). Soybean (Glycine max) allergy in Europe: gly $\mathrm{m} 5$ (beta-conglycinin) and Gly $\mathrm{m} 6$ (glycinin) are potential diagnostic markers for severe allergic reactions to soy. Journal of Allergy and Clinical Immunology, 123, 452-458. https://doi.org/10.1016/j.jaci.2008.09.034.

Houston, N. L., Lee, D. G., Stevenson, S. E., Ladics, G. S., Bannon, G. A., McClain, S., Privalle, L., Stagg, N., Herouet-Guicheney, C., Maclntosh, S. C., \& Thelen, J. J. (2011). Quantitation of Soybean Allergens Using Tandem Mass Spectrometry. Journal of Proteome Research, 10, 763-773. https://doi.org/10.1021/pr100913w.

Huschek, G., Bönick, J., Löwenstein, Y., Sievers, S., \& Rawel, H. (2016). Quantification of allergenic plant traces in baked products by targeted proteomics using isotope marked 
858

859

860

861

862

863

864

865

866

867

868

869

870

871

872

peptides. LWT - Food Science and Technology, 74, 286-293. https://doi.org/10.1016/j.Iwt.2016.07.057.

Inman, S. E., Groves, K., McCullough, B., Quaglia, M., \& Hopley, C. (2018). Development of a LC-MS method for the discrimination between trace level Prunus contaminants of spices. Food Chemistry, 245, 289-296. https://doi.org/10.1016/j.foodchem.2017.10.101.

Ji, J., Zhu, P., Pi, F., Sun, C., Sun, J., Jia, M., Ying, C., Zhang, Y., \& Sun, X. (2017).

Development of a liquid chromatography-tandem mass spectrometry method for simultaneous detection of the main milk allergens. Food Control, 74, 79-88. https://doi.org/10.1016/j.foodcont.2016.11.030.

Ke, X., Zhang, J., Lai, S., Chen, Q., Zhang, Y., Jiang, Y., Mo, W., \& Ren, Y. (2017). Quantitative analysis of cow whole milk and whey powder adulteration percentage in goat and sheep milk products by isotopic dilution-ultra-high performance liquid chromatography-tandem mass spectrometry. Analytical and Bioanalytical Chemistry, 409, 213-224. https://doi.org/10.1007/s00216-016-9987-9.

Korte, R., Lepski, S., \& Brockmeyer, J. (2016a). Comprehensive peptide marker identification for the detection of multiple nut allergens using a non-targeted LC-HRMS multi-method. Analytical and Bioanalytical Chemistry, 408, 3059-3069. https://doi.org/10.1007/s00216-0169384-4.

Korte, R., \& Brockmeyer, J. (2016b). MRM3-based LC-MS multi-method for the detection and quantification of nut allergens. Analytical and Bioanalytical Chemistry, 408, 7845-7855. https://doi.org/10.1007/s00216-016-9888-y.

Korte, R., Oberleitner, D., Brockmeyer, J. (2019). Determination of food allergens by LC-MS: Impacts of sample preparation, food matrix, and thermal processing on peptide detectability and quantification. Journal of Proteomics, 196, 131-140. https://doi.org/10.1016/j.jprot.2018.11.002.

Lamberti, C., Acquadro, E., Corpillo, D., Giribaldi, M., Decastelli, L., Garino, C., Arlorio, M., Ricciardi, C., Cavallarin, L., \& Giuffrida, M. G. (2016). Validation of a mass spectrometry-based method for milk traces detection in baked food. Food Chemistry, 199, 119-127. https://doi.org/10.1016/j.foodchem.2015.11.130. 
Lee, J. Y. \& Kim, C. J. (2010). Determination of Allergenic Egg Proteins in Food by Protein-, Mass Spectrometry-, and DNA-Based Methods Journal of AOAC International, 93, 462-477.

Li, B., Gorman, E. M., Moore, K. D., Williams, T., Schowen, R. L., Topp, E. M., \& Borchardt, R. T. (2005). Effects of acidic $\mathrm{N}+1$ residues on asparagine deamidation rates in solution and in the solid state. Journal of Pharmaceutical Sciences, 94, 666-675. https://doi.org/10.1002/jps.20263.

Losito, I., Introna, B., Monaci, L., Minella, S., \& Palmisano, F. (2013). Development of a Method for the Quantification of Caseinate Traces in Italian Commercial White Wines Based on Liquid Chromatography-Electrospray Ionization-Ion Trap-Mass Spectrometry Journal of Agricultural and Food Chemistry, 61, 12436-12444. https://doi.org/10.1021/jf4034909.

Lutter, P., Parisod, V., \& Weymuth, H. (2011). Development and Validation of a Method for the Quantification of Milk Proteins in Food Products Based on Liquid Chromatography with Mass Spectrometric Detection. Journal of AOAC International, 94, 1043-1059.

Ma, B., \& Johnson, R. (2012). De novo sequencing and homology searching. Molecular \& Cellular Proteomics, 11, 0111.014902. https://doi.org/10.1074/mcp.0111.014902.

Mattarozzi, M., Milioli, M., Bignardi, C., Elviri, L., Corradini, C., \& Careri, M. (2014). Investigation of different sample pre-treatment routes for liquid chromatography-tandem mass spectrometry detection of caseins and ovalbumin in fortified red wine. Food Control, 38, 82-87. https://doi.org/10.1016/j.foodcont.2013.10.015.

Mills, E.N.C., Adel-Patiet, K., Bernard, H., De Loose, M., Gillard, N., Huet, A.-C., Larré, C., Nitride, C., Pilolli, R., Tranquet, O., Van Poucke, C., Monaci, L. (2019). Detection and Quantification of Allergens in Foods and Minimum Eliciting Doses in Food-Allergic Individuals (ThRAII). Journal of AOA C International, 102, 1-8. https://doi.org/10.5740/jaoacint.19-0063.

Monaci, L., Tregoat, V., van Hengel, A. J., \& Anklam, E. (2006). Milk allergens, their characteristics and their detection in food: a review. European Food Research and Technology, 223, 149-79. https://doi.org/10.1007/s00217-005-0178-8.

Monaci, L., Losito, I., Palmisano, F., \& Visconti, A. (2010a). Identification of allergenic milk proteins markers in fined white wines by capillary liquid chromatography-electrospray 
915 ionization-tandem mass spectrometry. Journal of Chromatography A, 1217, 4300-4305. 916 https://doi.org/10.1016/j.chroma.2010.04.035.

917 Monaci L., Nørgaard, J.V., \& van Hengel, A. J. (2010b). Feasibility of a capillary LC/ESI-Q-TOF 918 MS method for the detection of milk allergens in an incurred model food matrix. Analytical 919 Methods, 2, 967-972. https://doi.org/10.1039/C0AY00151A.

920 Monaci, L., Losito, I., Palmisano, F., Godula, M., \& Visconti, A. (2011). Towards the 921 quantification of residual milk allergens in caseinate-fined white wines using HPLC coupled with 922 single-stage Orbitrap mass spectrometry. Food additives and Contaminants: Part A, 28, 1304923 1314. https://doi.org/10.1080/19440049.2011.593191.

924 Monaci, L., Losito, I., De Angelis, E., Pilolli, R., \& Visconti, A. (2013). Multi-allergen 925 quantification of fining-related egg and milk proteins in white wines by high-resolution mass 926 spectrometry. Rapid Communications in Mass Spectrometry, 27, 2009-2018. 927 https://doi.org/10.1002/rcm.6662.

928 Monaci, L., Pilolli, R., De Angelis, E., Godula, M., \& Visconti, A. (2014). Multi-allergen detection 929 in food by micro high-performance liquid chromatography coupled to a dual cell linear ion trap 930 mass spectrometry. Journal of Chromatography $A$, 1358, 136-144. 931 https://doi/org/10.1016/j.chroma.2014.06.092.

932 Monaci, L., De Angelis, E., Montemurro, N., \& Pilolli, R. (2018). Comprehensive overview and 933 recent advances in proteomics MS based methods for food allergens analysis. Trends in 934 Analytical Chemistry, 106, 21-36. https://doi.org/10.1016/j.trac.2018.06.016.

935 Montowska, M., \& Fornal, E. (2018). Detection of peptide markers of soy, milk and egg white 936 allergenic proteins in poultry products by LC-Q-TOF-MS/MS. LWT - Food Science and 937 Technology, 87, 310-317. https://doi.org/10.1016/j.Iwt.2017.08.091.

938 Montowska, M., \& Fornal, E. (2019). Absolute quantification of targeted meat and allergenic 939 protein additive peptide markers in meat products. Food Chemistry, 274, 857-864. 940 https://doi.org/10.1016/j.foodchem.2018.08.131. 
941 New, L. S., Schreiber, A., Stahl-Zeng, J., \& Liu, H. F. (2018). Simultaneous Analysis of Multiple Allergens in Food Products by LC-MS/MS. Journal of AOAC International, 101, 132-145. https://doi.org/10.5740/jaoacint.17-0403.

Newsome, G. A., \& Scholl, P. F. (2013). Quantification of allergenic bovine milk a(S1)-casein in baked goods using an intact ${ }^{15} \mathrm{~N}$-labeled protein internal standard. Journal of Agricultural and Food Chemistry, 61, 5659-5668. https://doi.org/10.1021/jf3015238.

Nielsen, N. C., Dickinson, C. D., Cho, T. J., Thanh, V. H., Scallon, B. J., Fischer, R. L., Sims, T. L., Drews, G. N., Goldberg, R. B. (1989). Characterization of the glycinin gene family in soybean. The Plant Cell, 1, 313-328. https://doi.org/10.1105/tpc.1.3.313.

Nitride, C., Mamone, G., Picariello, G., Mills, E.N.C., Nocerino, R., Berni Canani, R., \& Ferranti, P. (2013). Proteomic and immunological characterization of a new food allergen from hazelnut (Corylus avellana). Journal of proteomics, 86, 16-26. https://doi.org/10.1016/j.jprot.2013.05.001.

Palladino, C., \& Breiteneder H. (2018). Peanut allergens. Molecular Immunology, 100, 58-70. https://doi.org/10.1016/j.molimm.2018.04.005.

Parker, C. H., Khuda, S. E., Pereira, M., Ross, M. M., Fu, T.J., Fan, X., Wu, Y., Williams, K. M., DeVries, J., Pulvermacher, B., Bedford, B., Zhang, X., Jackson, L. S. (2015). Multi-allergen Quantitation and the Impact of Thermal Treatment in Industry-Processed Baked Goods by ELISA and Liquid Chromatography-Tandem Mass Spectrometry. Journal of Agricultural and Food Chemistry, 63, 10669-10680. https://doi.org/10.1021/acs.jafc.5b04287.

Pastorello, E. A., Vieths, S., Pravettoni, V., Farioli, L., Trambaioli, C., Fortunato, D., Lüttkopf, D., Calamari, M., Ansaloni, R., Scibilia, J., Ballmer-Weber, B. K., Poulsen, L. K., Wütrich, B., Hansen, K. S., Robino, A. M., Ortolani, C., \& Conti, A. (2002). Identification of hazelnut major allergens in sensitive patients with positive double-blind, placebo-controlled food challenge results. Journal of Allergy and Clinical Immunology, 109, 563-570. https://doi.org/10.1067/mai.2002.121946.

Pavón-Pérez, J., Henriquez-Aedo, K., Aranda, M. (2019). Mass Spectrometry Determination of Fining-Related Allergen Proteins in Chilean Wines. Food Analytical Methods, 12, 827-837. https://doi.org/10.1007/s12161-018-01416-0. 
970 Pedreschi R., Nørgaard, J., \& Maquet, A. (2012). Current Challenges in Detecting Food 971 Allergens by Shotgun and Targeted Proteomic Approaches: A Case Study on Traces of Peanut 972 Allergens in Baked Cookies. Nutrients, 4, 132-150. https://doi.org/10.3390/nu4020132.

973 Pfeifer, S., Bublin, M., Dubiela, P., Hummel, K., Wortmann, J., Hofer, G., Keller, W., Radauer, 974 C., \& Hoffmann-Sommergruber, K. (2015). Cor a 14, the allergenic $2 S$ albumin from hazelnut, 975 is highly thermostable and resistant to gastrointestinal digestion. Molecular Nutrition \& Food 976 Research, 59, 2077-2086. https://doi.org/10.1002/mnfr.201500071.

977 Pilolli, R., De Angelis, E., Godula, M., Visconti, A., \& Monaci, L. (2014). Orbitrap ${ }^{\mathrm{TM}}$ monostage 978 MS versus hybrid linear ion trap MS: application to multi-allergen screening in wine. Journal of 979 Mass Spectrometry, 49, 1254-1263. https://doi.org/10.1002/jms.3453.

980 Pilolli, R., De Angelis, E., \& Monaci, L. (2017a). Streamlining the analytical workflow for 981 multiplex MS/MS allergen detection in processed foods. Food Chemistry, 221, 1747-1753. 982 https://doi.org/10.1016/j.foodchem.2016.10.110.

983 Pilolli, R., Chaudhari, R., Palmisano, F., \& Monaci, L. (2017b). Development of a mass 984 spectrometry immunoassay for unambiguous detection of egg allergen traces in wines. 985 Analytical and Bioanalytical Chemistry, 409, 1581-1589. https://doi.org/10.1007/s00216-016$986 \quad 0099-3$.

987 Pilolli, R., De Angelis, E., \& Monaci, L. (2018). In house validation of a high resolution mass 988 spectrometry Orbitrap-based method for multiple allergen detection in a processed model food. 989 Analytical and Bioanalytical Chemistry, 410, 5653-5662. https://doi.org/10.1007/s00216-018$990 \quad 0927-8$

991 Planque, M., Arnould, T., Dieu, M., Delahaut, P., Renard, P., \& Gillard, N. (2016). Advances in 992 ultra-high performance liquid chromatography coupled to tandem mass spectrometry for 993 sensitive detection of several food allergens in complex and processed foodstuffs. Journal of 994 Chromatography A, 1464, 115-123. https://doi.org/10.1016/j.chroma.2016.08.033.

995 Planque, M., Arnould, T., Renard, P., Delahaut, P., Dieu, M., \& Gillard, N. (2017a) Highlight on 996 Bottlenecks in Food Allergen Analysis: Detection and Quantification by Mass Spectrometry. 997 Journal of AOA International, 100, 1-5. https://doi.org/10.5740/jaoacint.17-0005. 
998 Planque, M., Arnould, T., Dieu, M., Delahaut, P., Renard, P., \& Gillard, N. (2017b). Liquid 999 chromatography coupled to tandem mass spectrometry fordetecting ten allergens in complex 1000 and incurred foodstuffs. Journal of Chromatography A, 1530, 138-151. 1001 https://doi.org/10.1016/j.chroma.2017.11.039.

1002 Planque, M., Arnould, T., Delahaut, P., Renard, P., Dieu, M., \& Gillard, N. (2019). Development 1003 of a strategy for the quantification of food allergens in several food products by mass 1004 spectrometry in a routine laboratory. Food Chem. 274, 35-45. 1005 https://doi.org/10.1016/j.foodchem.2018.08.095.

1006 Pomés, A., Davies, J. M., Gadermaier, G., Hilger, C., Holzhauser, T., Lidholm, J., Lopata, A. 1007 L., Mueller, G. A., Nandy, A., Radauer, C., Chan, S. K., Jappe, U., Kleine-Tebbe, J., Thomas, 1008 W. R., Chapman, M. D., van Hage, M., van Ree, R., Vieths, S., Raulf, M., Goodman, R. E., \& 1009 WHO IUIS Allergen Nomenclature Sub-Committee. (2018). WHO/IUIS Allergen Nomenclature: 1010 Providing a common language. Molecular Immunology 100, 3-13. 1011 https://doi.org/10.1016/j.molimm.2018.03.003.

1012 Qi, K., Liu, T., Yang, Y., Zhang, J., Yin, J., Ding, X., Qinc, W., Yang, Y. (2019). A rapid 1013 immobilized trypsin digestion combined with liquid chromatography - Tandem mass 1014 spectrometry for the detection of milk allergens in baked food. Food Control, 102, 179-187. 1015 https://doi.org/10.1016/j.foodcont.2019.03.017

1016 Sayers, R. L., Johnson, P. E., Marsh, J. T., Barran, P., Brown, H., \& Mills, E. N. C. (2016). The 1017 effect of thermal processing on the behaviour of peanut allergen peptide targets used in multiple 1018 reaction monitoring mass spectrometry experiments. Analyst, 141, 4130-4141. 1019 https://doi.org/10.1039/c6an00359a.

1020 Sayers, R. L., Gethings, L. A., Lee, V., Balasundaram, A., Johnson, P. E., Marsh, J. A., Wallace, 1021 A., Brown, H., Rogers, A., Langridge, J. I., \& Mills, E. N. C. (2018). Microfluidic separation 1022 coupled to mass spectrometry for quantification of peanut allergens in a complex food matrix. 1023 Journal of Proteome Research, 17, 647-655. https://doi.org/10.1021/acs.jproteome.7b00714. 1024 Schocker, F., Lüttkopf, D., Scheurer, S., Petersen, A., Cisteró-Bahima, A., Enrique, E., San 1025 Miguel-Moncín, M., Akkerdaas, J., Van Ree, R., Vieths, S., \& Becker, W. M. (2004). 1026 Recombinant lipid transfer protein Cor a 8 from hazelnut: a new tool for in vitro diagnosis of 
potentially severe hazelnut allergy. Journal of Allergy and Clinical Immunology, 113, 141-147. https://doi.org/10.1016/j.jaci.2003.09.013.

Scott, H., Sicherer, M.D., High, A., Sampson, M.D. (2018). Food allergy: A review and update on epidemiology, pathogenesis, diagnosis, prevention, and management. Journal of Allergy and Clinical Immunology, 141, 41-58. https://doi.org/10.1016/j.jaci.2017.11.003.

Shefcheck, K. J., Callahan, J. H., \& Musser, S. M. (2006). Confirmation of Peanut Protein Using Peptide Markers in Dark Chocolate Using Liquid Chromatography-Tandem Mass Spectrometry (LC-MS/MS). Journal of Agricultural and Food Chemistry, 54, 7953-7959. https://doi.org/10.1021/jf060714e.

Smýkal, P., Coyne, C.J., Ambrose, M.J., Maxted, N., Schaefer, H., Blair, M. W., Berger, J., Greene, S. L., Nelson, M. N., Besharat, N., Vymyslický, T., Toker, C., Saxena, R. K., Roorkiwal, M., Pandey, M. K., Hu, J., Li, Y. H., Wang, L. X., Guo, Y., Qiu, L. J., Redden, R. J., \& Varshney, R. K. (2015). Legume Crops Phylogeny and Genetic Diversity for Science and Breeding. Critical Reviews in Plant Sciences, 34, 43-104. https://doi.org/10.1080/07352689.2014.897904.

Tolin, S., Pasini, G., Simonato, B., Mainente, F., \& Arrigoni, G. (2012a). Analysis of commercial wines by LC-MS/MS reveals the presence of residual milk and egg white allergens. Food Control, 28, 321-326. https://doi.org/10.1016/j.foodcont.2012.05.015.

Tolin, S., Pasini, G., Curioni, A., Arrigoni, G., Masi, F., Mainente, F., \& Simonato, B. (2012b). Mass spectrometry detection of egg proteins in red wines treated with egg white. Food Control, 23, 87-94. https://doi.org/10.1016/j.foodcont.2011.06.016.

Turner, P. J., Gowland, M. H., Sharma, V, lerodiakonou, D., Harper, N., Garcez, T., Pumphrey, R., \& Boyle, R. J. (2015). Increase in anaphylaxis-related hospitalizations but no increase in fatalities: an analysis of United Kingdom national anaphylaxis data, 1992-2012. Journal of Allergy and Clinical Immunology, 135, 956-63. https://doi.org/10.1016/j.jaci.2014.10.021.

Vandekerckhove, M., Van Droogenbroeck, B., De Loose, M., Taverniers, I., Daeseleire, E., Gevaert, P., Lapeere, H., \& Van Poucke, C. (2017). Development of an LC-MS/MS method for the detection of traces of peanut allergens in chili pepper. Analytical and Bioanalytical Chemistry, 409, 5201-5207. https://doi.org/10.1007/s00216-017-0506-4. 
1055 Verma, A. K., Kumar, S., Das, M., \& Dwivedi, P. D. (2013). A Comprehensive Review of 1056 Legume Allergy. Clinical Review in Allergy and Immunology, 45, 30-46. 1057 https://doi.org/10.1007/s12016-012-8310-6.

1058 Verweij, M. M., Hagendorens, M. M., Trashin, S., Cucu, T., De Meulenaer, B., Devreese, B., 1059 Bridts, C. H., De Clerck, L. S., \& Ebo, D. G. (2012). Age-dependent sensitization to the 7S1060 vicilin like protein Cor a 11 from hazelnut (Corylus avellana) in a birch-endemic region. Journal 1061 of Investigational Allergology and Clinical Immunology, 22, 245-251.

1062 Viquez, O. M., Konan, K. N., \& Dodo, H. W. (2004). Genomic organization of peanut allergen 1063 gene, Ara h 3. Molecular Immunology, 41, 1235-1240. 1064 https://doi.org/10.1016/j.molimm.2004.06.033.

1065 Wal, J. (2001). Structure and function of milk allergens. Allergy, 56, 35-38. 1066 https://doi.org/10.1034/j.1398-9995.2001.00911.x

1067 Wang, T., Qin, G.-X., Sun, Z.-W., \& Zhao, Y. (2014). Advances of Research on Glycinin and $\beta-$ 1068 Conglycinin: A Review of Two Major Soybean Allergenic Proteins. Critical Review in Food 1069 Science and Nutrition, 54, 850-862. https://doi.org/10.1080/10408398.2011.613534.

1070 Worm, M., Moneret-Vautrin, A., Scherer, K., Lang, R., Fernandez-Rivas, M., Cardona, V., 1071 Kowalski, M. L., Jutel, M., Poziomkowska-Gesicka, I., Papadopoulos, N. G., Beyer, K., 1072 Mustakov, T., Christoff, G., Bilò, M. B., Muraro, A., Hourihane, J. O., \& Grabenhenrich, L. B. 1073 (2014). First European data from the network of severe allergic reactions (NORA). Allergy, 69, 1074 1397-404. https://doi.org/10.1111/all.12475.

1075 Yang, W., Liqing, W., Fei, D., Bin, Y., Yi, Y., Jing, W. (2014). Development of an SI-traceable 1076 HPLC-isotope dilution mass spectrometry method to quantify $\beta$-lactoglobulin in milk powders. 1077 Journal of Agricultural and Food Chemistry, 62, 3073-3080. https://doi.org/10.1021/jf4054337.

1078 Zhang, J., Hong, Y., Cai, Z., Huang, B., Wang, J., Ren, Y. (2019). Simultaneous determination 1079 of major peanut allergens Ara h1 and Ara h2 in baked foodstuffs based on their signature 1080 peptides using ultraperformance liquid chromatography coupled to tandem mass spectrometry. 1081 Analytical Methods, 11, 1689-1696. https://doi.org/10.1039/c9ay00256a. 
1083 FIGURES AND TABLES

1084 Figure 1 (color online version only)

1085

1.1 Allergen Peptide

on-line (access in July

2018).

1.2 Svstematic literature

review to collect futh
relevant papers.

2.2 Food matrix

Filter validated in at

based or thermally

matrix.

2. Peptides evaluation and filtering

EGG

Evaluation of the kind

of investigation reported

Filter preferentially

peptides already

MILK assessed in targeted

PEANUT

SOYBEAN

2.4 AA prone to

endogeneous an

HAZELNUT

modification

ALMOND

Filter. Excluding

sequences containing

containing $C, N, Q$

3. Adelitional infor

3.1 Relative abundance

Filter. most abundant.

post-translational or

rocessing-induced)

Filter: Protein should

ideally not be subject

suggested a case-by-

suggested a case-

case evaluation.

3 Isoforms/variants

Filter. Whenever

possible, conserved

known isoforms.

Alternatively, seiect

more peptides cover

all known isoforms.

sources: scientific

pubblications, Uniprot $D B$

Alergome DB, WHORUIS

database, (access in

\begin{tabular}{|c|}
\hline $\begin{array}{l}\text { 4. Peptide specificity } \\
\text { sequence similarity }\end{array}$ \\
\hline $\begin{array}{l}4.1 \text { BLAST search taking } \\
\text { into consideration the } \\
\text { specific enzymatic } \\
\text { cleavage applied. }\end{array}$ \\
\hline $\begin{array}{l}\text { Filler. Peptide } \\
\text { sequence should not } \\
\text { be shared with any } \\
\text { other allergen and any } \\
\text { other common food } \\
\text { ingredient. }\end{array}$ \\
\hline $\begin{array}{l}4.2 \text { For plant-derived } \\
\text { peptides, search for } \\
\text { sequences similarity }\end{array}$ \\
\hline $\begin{array}{l}\text { Filter. 1 AA mismatch, } \\
\text { difference in molecular } \\
\text { weight within } \pm 1 \mathrm{Da} \text {. }\end{array}$ \\
\hline $\begin{array}{l}\text { sources: MS-Homology, } \\
\text { Protein Prospector v } \\
\text { 5.22.1, (access in October } \\
\text { 2018); blastp - NCBI DB } \\
\text { (access in July 2018). }\end{array}$ \\
\hline
\end{tabular}

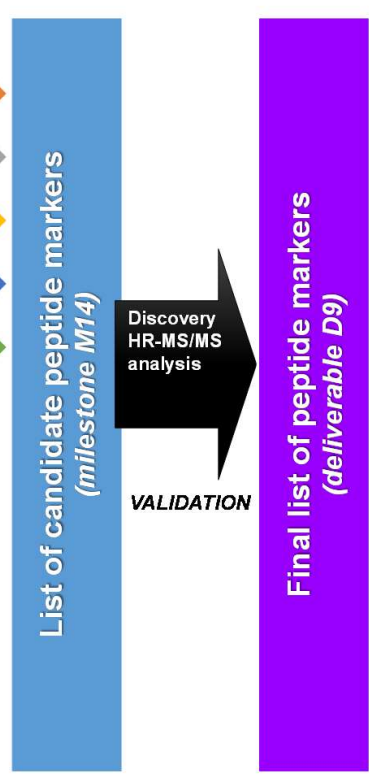

1087 

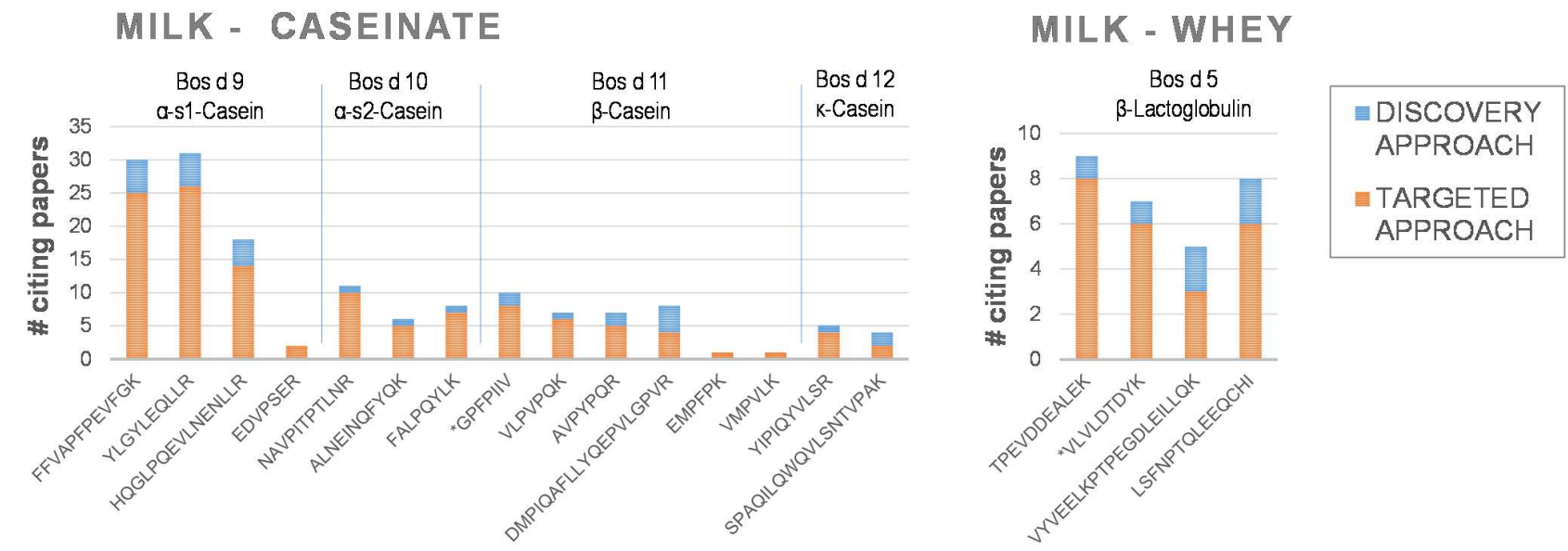

\section{EGG - WHITE}

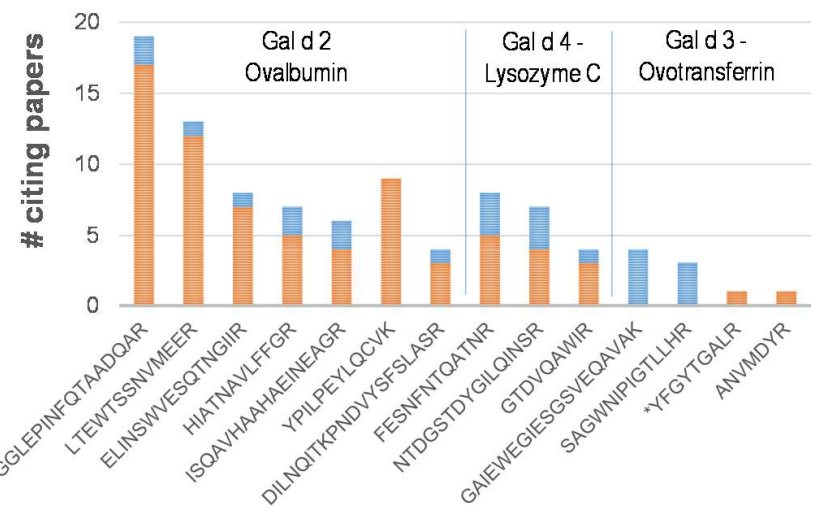

EGG - YOLK

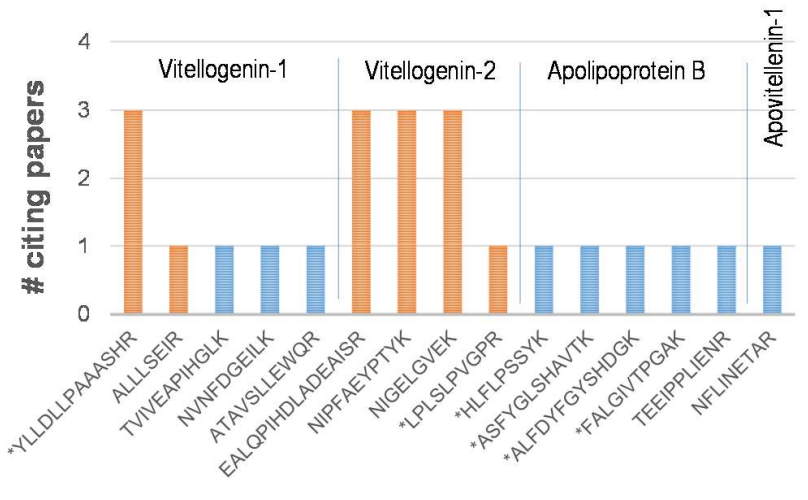


Figure 3

1093

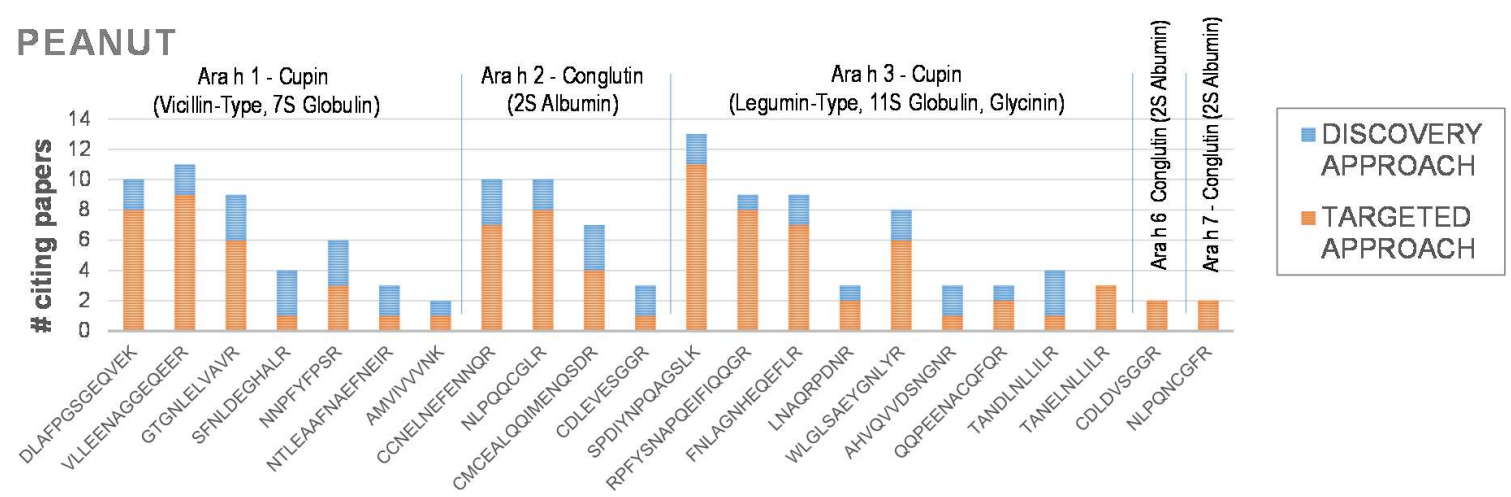

SOYBEAN
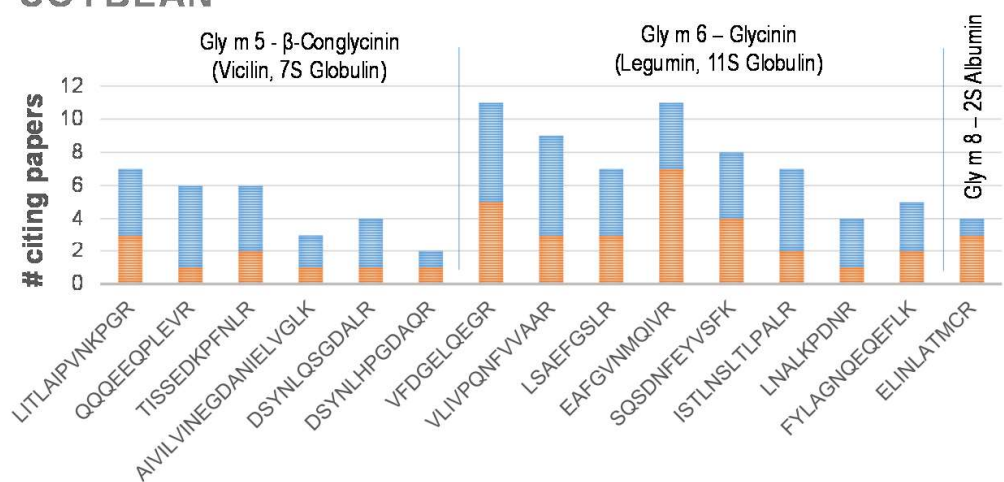

\section{HAZELNUT}

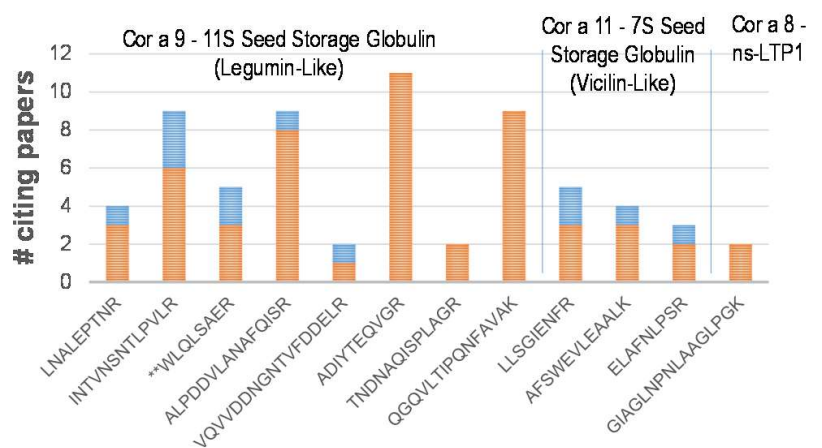

ALMOND

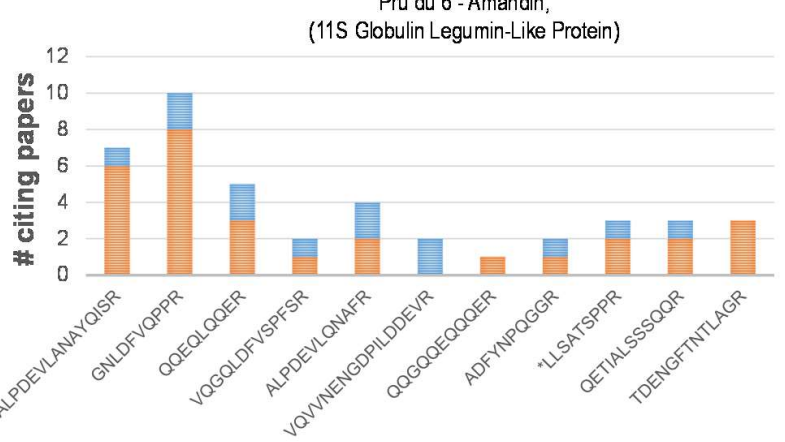




\section{Table 1}

\begin{tabular}{|c|c|c|c|c|c|c|c|c|}
\hline $\begin{array}{l}\text { Allergenic } \\
\text { ingredient }\end{array}$ & Protein & Allergen Name & MW (kDa) & Number of known PTMs* & $\begin{array}{l}\text { Isoforms and } \\
\text { Variants }\end{array}$ & $\begin{array}{l}\text { IUIS } \\
\text { (YES/NO) }\end{array}$ & GenBank Protein & UniProt \\
\hline \multirow[t]{8}{*}{ Milk } & aS1-Casein & Bos d 9 & 23.6 & $\begin{array}{l}\mathrm{n}^{\circ} 9 \text { Ser } \\
\text { phosphorylationsphosphoryl } \\
\text { ations }\end{array}$ & Bos d 9.0101 & Yes & NP_851372 & P02662 \\
\hline & $\alpha \mathrm{S} 2-$ Casein & Bos d 10 & 25.2 & $\begin{array}{l}\mathrm{n}^{\circ} 13 \text { Ser } \\
\text { phosphorylationsphosphoryl } \\
\text { ations }\end{array}$ & Bos d 10.0101 & Yes & NP_776953 & P02663 \\
\hline & $\beta$-Casein & Bos d 11 & 24 & $\begin{array}{l}\mathrm{n}^{\circ} 5 \text { Ser } \\
\text { phosphorylationsphosphoryl } \\
\text { ations }\end{array}$ & Bos d 11.0101 & Yes & XP_005902099 & P02666 \\
\hline & $\mathrm{k}$-Casein & Bos d 12 & 19 & $\begin{array}{l}n^{\circ} 1 \text { N-terminal Gln } \\
\text { cyclization to pyroglutamate } \\
n^{\circ} 3 \text { Disulfide Bonds } \\
n^{\circ} 3 \text { Ser } \\
\text { phosphorylationsphosphoryl } \\
\text { ations } \\
n^{\circ} 1 \text { Thr phosphorylation } \\
n^{\circ} 6 \text { Thr glycosylations } \\
n^{\circ} 2 \text { Ser glycosylations }\end{array}$ & Bos d 12.0101 & Yes & NP_776719 & P02668 \\
\hline & a-Lactalbumin & Bos d 4 & 14.2 & $\begin{array}{l}n^{\circ} 4 \text { Disulfide Bonds } \\
n^{\circ} 1 \text { Asn glycosylation }\end{array}$ & Bos d 4.0101 & Yes & AAA30615 & P00711 \\
\hline & $\beta$-Lactoglobulin & Bos d 5 & 18.3 & $\mathrm{n}^{\circ} 3$ Disulfide Bonds & Bos d 5.0101 & Yes & CAA32835 & P02754 \\
\hline & Bovine serum albumin & Bos d 6 & 66.3 & $\begin{array}{l}n^{\circ} 17 \text { Disulfide Bonds } \\
n^{\circ} 6 \text { Ser phosphorylations } \\
n^{\circ} 4 \text { Thr phosphorylations } \\
n^{\circ} 2 \text { N6-succinyllysine } \\
n^{\circ} 1 \text { Lys methylation }\end{array}$ & Bos d 6.0101 & Yes & AAA51411 & P02769 \\
\hline & Immunoglobulins & Bos d 7 & 160 & & Bos d 7.0101 & Yes & & \\
\hline \multirow[t]{9}{*}{ Egg } & Ovalbumin & Gal d 2 & 44 & $\begin{array}{l}\text { Initial Met Removal } \\
n^{\circ} 1 \text { Gly acetylation } \\
n^{\circ} 2 \text { Ser phosphorylations } \\
n^{\circ} 1 \text { Disulfide Bond } \\
n^{\circ} 1 \text { Asn glycosylation }\end{array}$ & Gal d 2.0101 & Yes & CAA23682 & P01012 \\
\hline & Ovomucoid & Gal d 1 & 28 & $\begin{array}{l}n^{\circ} 9 \text { Disulfide Bonds } \\
n^{\circ} 5 \text { Asn glycosylations }\end{array}$ & Gal d 1.0101 & Yes & P01005 & P01005 \\
\hline & Ovotransferrin & Gal d 3 & 78 & $\begin{array}{l}n^{\circ} 15 \text { Disulfide Bonds } \\
n^{\circ} 1 \text { Asn glycosylation }\end{array}$ & Gal d 3.0101 & Yes & CAA26040 & P02789 \\
\hline & Lysozyme C & Gal d 4 & 14 & $\mathrm{n}^{\circ} 4$ Disulfide Bonds & Gal d 4.0101 & Yes & CAA23711 & P00698 \\
\hline & Serum Albumin & Gal d 5 & 69 & $\begin{array}{l}n^{\circ} 17 \text { Disulfide Bonds } \\
n^{\circ} 1 \text { Asn glycosylation }\end{array}$ & Gal d 5.0101 & Yes & CAA43098 & P19121 \\
\hline & YGP42 & Gal d 6 & 35 & $\mathrm{n}^{\circ} 3$ Asn glycosylations & Gal d 6.0101 & Yes & BAA13973 & $\begin{array}{l}\text { chain } 1628-1912 \\
\text { of the P87498 }\end{array}$ \\
\hline & Myosin light chain 1f & Gal d 7 & 22 & $\mathrm{n}^{\circ} 1$ Ala trimethylation & Gal d 7.0101 & Yes & $\begin{array}{l}\text { K02608.1, K02609.1 } \\
\text { and K02610.1 }\end{array}$ & P02604 \\
\hline & alpha-parvalbumin & Gal d 8 & 11.8 & NA & Gal d 8.0101 & Yes & CAX32963 & C1L370 \\
\hline & Beta-enolase & Gal d 9 & 50 & $\mathrm{n}^{\circ} 1$ Ser acetylation & Gal d 9.0101 & Yes & NP_990450 & P07322 \\
\hline
\end{tabular}




\begin{tabular}{|c|c|c|c|c|c|c|c|c|}
\hline & & & & & & & & \\
\hline & Aldolase & Gal d 10 & & NA & Gal d 10.0101 & Yes & & \\
\hline \multirow[t]{32}{*}{ Peanut } & \multirow[t]{2}{*}{$\begin{array}{l}\text { Vicilin-type, 7S globulin } \\
\text { (Cupin) }\end{array}$} & \multirow[t]{2}{*}{ Ara h 1} & \multirow[t]{2}{*}{64} & \multirow[t]{2}{*}{$\mathrm{n}^{\circ} 1$ Asn glycosylation } & $\begin{array}{l}\text { Ara h } 1.0101 \\
\text { (clone P41B) }\end{array}$ & Yes & AAB00861 & P43238 \\
\hline & & & & & $\begin{array}{l}\text { Ara h } 1 \text { - Clone } \\
\text { P17 }\end{array}$ & No & AAA60336 & P43237 \\
\hline & \multirow{4}{*}{$\begin{array}{l}\text { Conglutin, 2S albumin } \\
\text { (Prolamin) }\end{array}$} & \multirow[t]{4}{*}{ Ara h 2} & \multirow[t]{4}{*}{17} & \multirow{4}{*}{$\begin{array}{l}n^{\circ} 3 \text { Pro hydroxylation } \\
n^{\circ} 4 \text { Disulfide Bonds }\end{array}$} & Ara h 2.0101 & Yes & AAK96887 & \\
\hline & & & & & Ara h 2.0102 & No & see Allergome & \\
\hline & & & & & Ara h 2.0201 & Yes & AAN77576 & \\
\hline & & & & & Ara h 2.0202 & No & see Allergome & \\
\hline & \multirow{4}{*}{$\begin{array}{l}\text { Legumin-type, Glycinin, 11S } \\
\text { globulin (Cupin) }\end{array}$} & \multirow[t]{4}{*}{ Ara h 3} & \multirow{4}{*}{$\begin{array}{l}60,37 \\
\text { (fragment) }\end{array}$} & \multirow[t]{4}{*}{ NA } & Ara h 3.0101 & Yes & AAC63045 & 082580 \\
\hline & & & & & Ara h 3.0201 & Yes & AAD47382 & Q9SQH7 \\
\hline & & & & & $\begin{array}{l}\text { Ara h } 3 \text { genomic } \\
\text { clone }\end{array}$ & No & AAM46958 & \\
\hline & & & & & Iso Ara h 3 & No & AAT39430 & \\
\hline & Profilin & Arah 5 & 15 & NA & Ara h 5.0101 & Yes & AAD55587 & Q9SQ19 \\
\hline & $\begin{array}{l}\text { Conglutin, 2S albumin } \\
\text { (Prolamin) }\end{array}$ & Ara h 6 & 15 & $\mathrm{n}^{\circ} 5$ Disulfide Bonds & Ara h 6.0101 & Yes & AAD56337 & Q647G9 \\
\hline & \multirow{3}{*}{$\begin{array}{l}\text { Conglutin, 2S albumin } \\
\text { (Prolamin) }\end{array}$} & \multirow[t]{3}{*}{ Ara h 7} & \multirow[t]{3}{*}{15} & \multirow[t]{3}{*}{ NA } & Ara h 7.0101 & Yes & AAD56719 & Q9SQH1 \\
\hline & & & & & Ara h 7.0201 & Yes & ABW17159 & B4XID4 \\
\hline & & & & & Ara h 7.0301 & Yes & AAU21496 & Q647G8 \\
\hline & \multirow{2}{*}{$\begin{array}{l}\text { Pathogenesis-related } \\
\text { protein, PR-10, (Bet } v 1 \text { like) }\end{array}$} & \multirow[t]{2}{*}{ Ara h 8} & \multirow[t]{2}{*}{17} & \multirow[t]{2}{*}{ NA } & Ara h 8.0101 & Yes & AAQ91847 & Q6VT83 \\
\hline & & & & & Ara h 8.0201 & Yes & ABP97433 & BOYIU5 \\
\hline & \multirow{2}{*}{$\begin{array}{l}\text { Nonspecific lipid-transfer } \\
\text { protein type } 1 \text { (Prolamin) }\end{array}$} & \multirow[t]{2}{*}{ Ara h 9} & \multirow[t]{2}{*}{9.8} & \multirow[t]{2}{*}{ Disulfide bond } & Ara h 9.0101 & Yes & ABX56711 & B6CEX8 \\
\hline & & & & & Ara h 9.0201 & Yes & ABX75045 & B6CG41 \\
\hline & \multirow{2}{*}{$\begin{array}{l}16 \mathrm{kDa} \text { oleosin (Glycosyl } \\
\text { transferase GT-C) }\end{array}$} & \multirow[t]{2}{*}{ Ara h 10} & 16 & NA & Ara h 10.0101 & Yes & AAU21499 & Q647G5 \\
\hline & & & & & Ara h 10.0102 & Yes & AAU21500 & Q647G4 \\
\hline & 14 kDa oleosin (Glycosyl & Ara h 11 & 14 & NA & Ara h 11.0101 & Yes & AAZ20276 & Q45W87 \\
\hline & transferase GT-C) & & & & Ara h 11.0102 & Yes & AAZ20277 & Q45W86 \\
\hline & $\begin{array}{l}\text { Defensin (Scorpion toxin-like } \\
\text { knottin) }\end{array}$ & Ara h 12 & $\begin{array}{l}8 \mathrm{kDa} \\
\text { (reducing), } 12 \\
\mathrm{kDa} \text { (non- } \\
\text { reducing), } 5.184 \\
\mathrm{kDa} \text { (mass) }\end{array}$ & NA & Ara h 12.0101 & Yes & & \\
\hline & Defensin (Scorpion toxin-like & Ara h 13 & $8 \mathrm{kDa}$ & NA & Ara h 13.0101 & Yes & & \\
\hline & knottin) & & $\begin{array}{l}\text { (reducing), } 11 \\
\text { kDa (non- } \\
\text { reducing), } 5.472 \\
\text { kDa (mass) }\end{array}$ & & Ara h 13.0201 & Yes & & \\
\hline & Oleosin (Glycosyl & Ara h 14 & 17.5 & NA & Ara h 14.0101 & Yes & AAK13449 & Q9AXI1 \\
\hline & transferase GT-C) & & & & Ara h 14.0102 & Yes & AAK13450 & Q9AXI0 \\
\hline & & & & & Ara h 14.0103 & Yes & AAT11925 & Q6J1J8 \\
\hline & $\begin{array}{l}\text { Oleosin (Glycosyl } \\
\text { transferase GT-C) }\end{array}$ & Ara h 15 & 17 & NA & Ara h 15.0101 & Yes & AAU21501 & Q647G3 \\
\hline & $\begin{array}{l}\text { non-specific Lipid Transfer } \\
\text { Protein } 2 \text { (Prolamin) }\end{array}$ & Ara h 16 & 8.5 (reducing) & NA & Ara h 16.0101 & Yes & & \\
\hline & $\begin{array}{l}\text { non-specific Lipid Transfer } \\
\text { Protein } 1 \text { (Prolamin) }\end{array}$ & Ara h 17 & 11 (reducing) & NA & Ara h 17.0101 & Yes & & \\
\hline Hazelnut & & Cor a 1 & 17 & Initial Met Removal & Cor a 1.0101 & Yes & CAA50327 & Q08407 \\
\hline
\end{tabular}




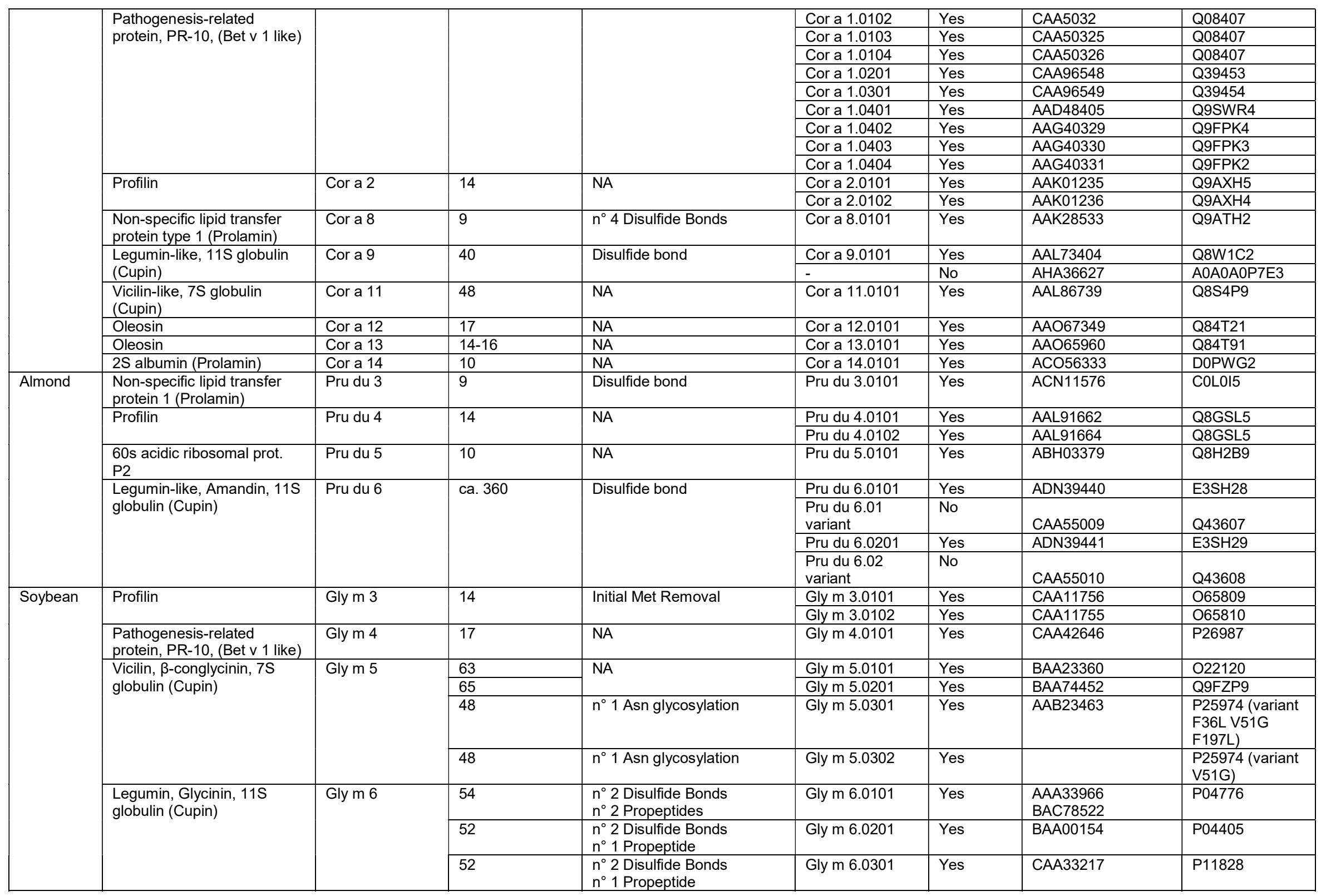




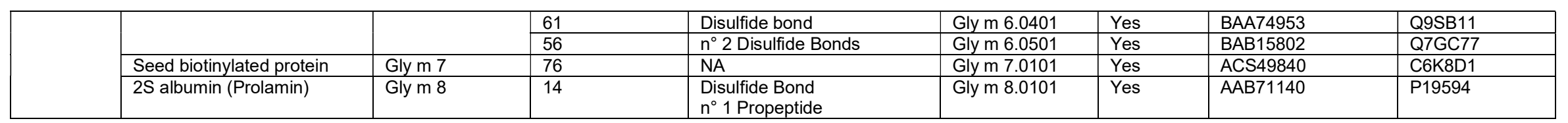


Table 2

\begin{tabular}{|c|c|c|c|c|c|c|c|c|c|c|c|}
\hline \multirow{3}{*}{$\begin{array}{l}\begin{array}{c}\text { Target } \\
\text { protein }\end{array} \\
\text { Bos d } 9- \\
\text { a-S1-Casein }\end{array}$} & \multirow{2}{*}{\begin{tabular}{l}
\multicolumn{1}{c}{$\begin{array}{c}\text { Peptide Sequence } \\
\text { Isoallergens/variants }\end{array}$} \\
FFVAPFPEVFGK \\
Bos $d 9.0101$
\end{tabular}} & \multirow{2}{*}{\begin{tabular}{l}
\multicolumn{1}{|c|}{ Specificity (Tax ID) } \\
Bos taurus (9913) \\
Bos mutus (72004) \\
Bubalus bubalis (89462)
\end{tabular}} & \multirow[b]{2}{*}{\begin{tabular}{l}
\multicolumn{1}{c}{ MS platform } \\
QqQ \\
QqQ \\
QqQ \\
IT \\
IT \\
Orbitrap \\
Orbitrap \\
Q-ToF \\
Q-ToF \\
Dual LIT \\
QqQ \\
QqQ \\
Dual LIT / Orbitrap \\
Dual LIT \\
QqQ \\
QqQ \\
QqQ \\
QqQ \\
QqQ \\
QqQ \\
QqQ \\
Q-Orbitrap \\
Dual LIT \\
QqQ \\
QqQ \\
QqQ
\end{tabular}} & \multirow[b]{2}{*}{$\begin{array}{l}\text { Precursor } \\
693.3(+2) \\
692.9(+2) \\
692.9(+2) \\
692.9(+2) \\
1384.6(+1) \\
692.9(+2) \\
692.9(+2) \\
692.6(+2) \\
692.9(+2) \\
692.9(+2) \\
692.9(+2) \\
692.9(+2) \\
692.9(+2) \\
692.9(+2) \\
692.9(+2) \\
692.9(+2) \\
692.9(+2) \\
692.9(+2) \\
692.9(+2) \\
692.9(+2) \\
692.9(+2) \\
692.9(+2) \\
692.9(+2) \\
692.9(+2) \\
692.9(+2) \\
692.8(+2)\end{array}$} & \multicolumn{2}{|c|}{ Transition 1} & \multicolumn{2}{|c|}{ Transition 2} & \multicolumn{2}{|c|}{ Transition 3} & \multirow[b]{2}{*}{\begin{tabular}{l}
\multicolumn{1}{c}{ References } \\
Ansari et al.,. 2011 \\
Heick et al., 2011a \\
Heick et al., 2011b \\
Lamberti et al., 2016 \\
Losito et al., 2013 \\
Monaci et al., 2013 \\
Monaci et al., 2011 \\
Monaci et al., 2010a \\
Monaci et al., 2010b \\
Monaci et al., 2014 \\
Newsome \& Scholl, 2013 \\
Parker et al., 2015 \\
Pilolli et al., 2014 \\
Pilolli et al., 2017a \\
Planque et al.l, 2016 \\
Planque et al.., 2017a \\
Planque et al., 2017b \\
Gu et al., 2018 \\
Boo et al., 2018 \\
Groves et al., 2018 \\
Ke et al., 2017 \\
Pilolli et al., 2018 \\
De Angelis et al., 2017b \\
Planque et al., 2019 \\
Qi et al., 2019 \\
Montowska \& Fornal, 2019
\end{tabular}} \\
\hline & & & & & $\begin{array}{l}920.8 \\
920.3 \\
920.3 \\
920.5 \\
-- \\
- \\
- \\
920.5 \\
920.5 \\
920.5 \\
920.5^{*} \\
920.5 \\
920.5^{*} \\
920.5 \\
920.5 \\
920.5 \\
920.5 \\
920.5 \\
920.5 \\
295.1^{*} \\
920.5 \\
920.5 \\
460.8^{\star} \\
1090.6\end{array}$ & 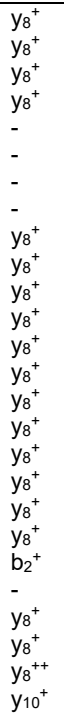 & $\begin{array}{l}676.6 \\
991.3 \\
991.3 \\
991.5 \\
- \\
- \\
- \\
- \\
676.4 \\
991.5 \\
991.5 \\
991.5 \\
991.5 \\
991.5 \\
991.5 \\
991.5 \\
991.5 \\
991.5 \\
991.5 \\
394.2 \\
991.5 \\
991.5 \\
496.3 \\
676.4\end{array}$ & 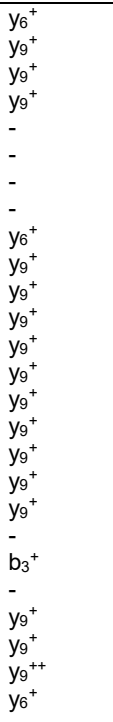 & $\begin{array}{l}267.3 \\
- \\
1090.6 \\
- \\
- \\
- \\
- \\
295.2 \\
- \\
1090.6 \\
1090.6 \\
- \\
545.8 \\
676.4 \\
676.4 \\
676.4 \\
676.4 \\
1090.6 \\
- \\
- \\
- \\
1090.6 \\
- \\
450.3\end{array}$ & $\begin{array}{l}\mathrm{a}_{2}^{+} \\
- \\
- \\
\mathrm{y}_{10^{+}} \\
- \\
- \\
- \\
- \\
\mathrm{b}_{2}{ }^{+} \\
- \\
\mathrm{y}_{10^{+}} \\
\mathrm{y}_{10^{+}} \\
\mathrm{y}_{10^{++}} \\
\mathrm{y}_{6}{ }^{+} \\
\mathrm{y}_{6} \\
\mathrm{y}_{6}{ }^{+} \\
\mathrm{y}_{10^{+}} \\
- \\
- \\
- \\
\mathrm{y}_{10^{+}} \\
- \\
- \\
\mathrm{y}_{4}{ }^{+}\end{array}$ & \\
\hline & $\begin{array}{l}\text { YLGYLEQLLR } \\
\text { Bos d } 9.0101\end{array}$ & $\begin{array}{l}\text { Bos taurus (9913) } \\
\text { Capra hircus (9925) } \\
\text { Ovis aries (9940) } \\
\text { Bubalus bubalis (89462) } \\
\text { Bos motus (72004) }\end{array}$ & $\begin{array}{l}\text { QqQ } \\
\text { QqQ } \\
\text { QqQ } \\
\text { IT } \\
\text { IT } \\
\text { LIT } \\
\text { Orbitrap } \\
\text { Orbitrap } \\
\text { Q-ToF } \\
\text { Q-ToF } \\
\text { Dual LIT } \\
\text { QqQ } \\
\text { QqQ } \\
\text { Dual LIT / Orbitrap } \\
\text { Dual LIT } \\
\text { QqQ } \\
\text { QqQ } \\
\text { QqQ-ToF } \\
\text { QqQ } \\
\text { QqQ } \\
\text { QqQ } \\
\text { QqQ } \\
\text { Q-Orbitrap } \\
\text { Dual LIT } \\
\text { QqQ } \\
\text { QqQ }\end{array}$ & $\begin{array}{l}634.8(+2) \\
634.3(+2) \\
634.3(+2) \\
634.4(+2) \\
1267.6(+1) \\
634.8(+2) \\
634.4+2) \\
634.4(+2) \\
634.2(+2) \\
634.3(+2) \\
634.4(+2) \\
634.4+2) \\
634.4(+2) \\
634.4(+2) \\
634.4(+2) \\
634.4(+2) \\
634.4(+2) \\
634.6(+2) \\
634.4(+2) \\
634.4(+2) \\
634.4(+2) \\
634.4(+2) \\
634.4+2) \\
634.4(+2) \\
634.4(+2) \\
634.4(+2) \\
\end{array}$ & $\begin{array}{l}991.7 \\
991.3 \\
991.3 \\
991.6 \\
-991.8 \\
-- \\
- \\
991.6 \\
991.6 \\
991.6 \\
991.6^{*} \\
991.6 \\
991.6 \\
934.5 \\
934.5 \\
991.3 \\
991.6 \\
991.6 \\
991.6 \\
991.6 \\
991.6 \\
934.5 \\
552.8 \\
\end{array}$ & 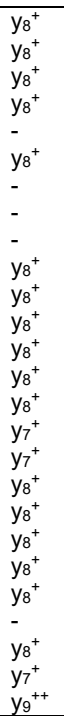 & $\begin{array}{l}771.8 \\
249.2 \\
249.2 \\
771.5 \\
- \\
771.4 \\
- \\
- \\
771.5 \\
771.5 \\
771.5 \\
771.5 \\
771.5 \\
771.5 \\
771.5 \\
771.5 \\
249.2 \\
771.5 \\
771.5 \\
249.2 \\
\\
771.5 \\
771.5 \\
249.1 \\
\end{array}$ & $\begin{array}{l}y_{6}{ }^{+} \\
a_{2}{ }^{+} \\
a_{2}^{+} \\
y_{6}{ }^{+} \\
- \\
y_{6}{ }^{+} \\
- \\
- \\
- \\
y_{6}{ }^{+} \\
y_{6}{ }^{+} \\
y_{6} 6^{+} \\
y_{6} 6^{+} \\
y_{6}{ }^{+} \\
y_{6}{ }^{+} \\
y_{6}{ }^{+} \\
a_{2}{ }^{+} \\
y_{6}{ }^{+} \\
y_{6}{ }^{+} \\
a_{2}^{+} \\
- \\
y_{6}{ }^{+} \\
y_{6}{ }^{+} \\
b_{4}\end{array}$ & $\begin{array}{l}658.4 \\
- \\
- \\
- \\
- \\
249.2 \\
- \\
- \\
658.4 \\
-658.4 \\
658.4 \\
658.4 \\
-658.4 \\
658.4 \\
- \\
- \\
- \\
658.4 \\
- \\
-\end{array}$ & 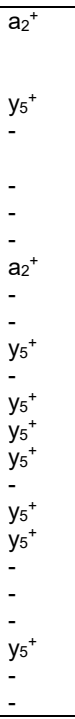 & $\begin{array}{l}\text { Ansari et al., 2011 } \\
\text { Heick et al., 2011a } \\
\text { Heick et al., 2011b } \\
\text { Lamberti et al., 2016 } \\
\text { Losito et al., 2013 } \\
\text { Mattarozzie al al., 2014 } \\
\text { Monaci et al., 2013 } \\
\text { Monaci et al., 2011 } \\
\text { Monaci et al., 2010a } \\
\text { Monaci et al., 2010b } \\
\text { Monaci et al., 2014 } \\
\text { Newsome \& Scholl, } 2013 \\
\text { Parker et al., 2015 } \\
\text { Pilolli et al., 2014 } \\
\text { Pilolli et al., 2017a } \\
\text { Planque et al.., 2016 } \\
\text { Planque et al., 2017b } \\
\text { Ji et al., 2017 } \\
\text { Gu et al., 2018 } \\
\text { Boo et al., 2018 } \\
\text { New et al., 2018 } \\
\text { Groves et al.,2018 } \\
\text { Pilolli et al.,. 2018 } \\
\text { De Angelis et al., 2017b } \\
\text { Planque et al.,, 2019 } \\
\text { Qi et al., 2019 }\end{array}$ \\
\hline
\end{tabular}




\begin{tabular}{|c|c|c|c|c|c|c|c|c|c|c|c|}
\hline & & & $\begin{array}{l}\mathrm{QqQ} \\
\mathrm{QqQ}\end{array}$ & $\begin{array}{l}634.4(+2) \\
634.6(+2)\end{array}$ & $\begin{array}{l}991.6 \\
991.8\end{array}$ & $\begin{array}{l}y_{8}^{+} \\
y_{8}^{+}\end{array}$ & $\begin{array}{l}771.5 \\
771.4\end{array}$ & $\begin{array}{l}y_{6^{+}}^{+} \\
y_{6}{ }^{+}\end{array}$ & 529.3 & $\mathrm{y}_{4}{ }^{+}$ & $\begin{array}{l}\text { Montowska \& Fornal, } 2019 \\
\text { Pavón-Pérez et al., } 2019\end{array}$ \\
\hline \multirow[t]{2}{*}{$\begin{array}{l}\text { Bos d } 10- \\
\text { aS2-Casein }\end{array}$} & $\begin{array}{l}\text { NAVPITPTLNR } \\
\text { Bos } d 10.0101\end{array}$ & $\begin{array}{l}\text { Bos taurus (9913) } \\
\text { Bubalus bubalis (89462) } \\
\text { Bos motus (72004) }\end{array}$ & $\begin{array}{l}\text { Q-ToF } \\
\text { QqQ } \\
\text { QqQ } \\
\text { Orbitrap } \\
\text { Q-ToF } \\
\text { QqQ } \\
\text { QqQ } \\
\text { QqQ } \\
\text { QqQ } \\
\text { QqQ } \\
\text { QqQ } \\
\end{array}$ & $\begin{array}{l}1195.7(+1) \\
598.3(+2) \\
598.3(+2) \\
598.3(+2) \\
598.4(+2) \\
598.3(+2) \\
598.3(+2) \\
598.3(+2) \\
598.3(+2) \\
598.3(+2) \\
598.4(+2) \\
\end{array}$ & $\begin{array}{l}911.4 \\
911.4 \\
911.4 \\
- \\
911.5 \\
911.5 \\
911.5 \\
912.0 \\
911.5 \\
911.6^{*}\end{array}$ & $\begin{array}{l}y_{8}{ }^{+} \\
y_{8}{ }^{+} \\
y_{8}{ }^{+} \\
- \\
y_{8} \\
y_{8}{ }^{+} \\
y_{8}{ }^{+} \\
y_{8} \\
y_{8}^{+} \\
y_{8}{ }^{+}\end{array}$ & $\begin{array}{l}701.4 \\
158.3 \\
158.3 \\
- \\
456.3 \\
456.3 \\
701.4 \\
285.5 \\
285.2 \\
456.3 \\
\end{array}$ & $\begin{array}{l}y_{6} 6^{+} \\
\mathrm{a}_{2}^{+} \\
\mathrm{a}_{2} 2^{+} \\
- \\
- \\
\mathrm{y}_{8} 8^{++} \\
\mathrm{y}_{8}{ }^{++} \\
\mathrm{y}_{6^{+}} \\
\mathrm{b}_{3} 3^{+} \\
\mathrm{y}_{8} 8^{++}\end{array}$ & $\begin{array}{l}600.3 \\
- \\
- \\
- \\
- \\
285.2 \\
285.2 \\
600.3 \\
- \\
- \\
-\end{array}$ & $\begin{array}{l}\mathrm{y}_{5}{ }^{+} \\
- \\
- \\
- \\
b_{3}{ }^{+} \\
b_{3}{ }^{+} \\
y_{5}{ }^{+} \\
- \\
- \\
-\end{array}$ & $\begin{array}{l}\text { Gomaa \& Boye, 2015 } \\
\text { Heick et al., 2011a } \\
\text { Heick et al., 2011b } \\
\text { Monaci et al., 2013 } \\
\text { Monaci et al., 2010a } \\
\text { Planque et al., 2016 } \\
\text { Planque et al., 2017b } \\
\text { Gu et al., 2018 } \\
\text { Ke et al., 2017 } \\
\text { Planque et al., } 2019 \\
\text { Qi et al., 2019 }\end{array}$ \\
\hline & $\begin{array}{l}\text { FALPQYLK } \\
\text { Bos } d 10.0101\end{array}$ & $\begin{array}{l}\text { Bos taurus (9913) } \\
\text { Bos motus (72004) }\end{array}$ & $\begin{array}{l}\text { QqQ } \\
\text { QqQ } \\
\text { IT } \\
\text { QqQ } \\
\text { Orbitrap } \\
\text { QqQ } \\
\text { QqQ } \\
\text { QqQ }\end{array}$ & $\begin{array}{l}490.3(+2) \\
490.3(+2) \\
979.3(+1) \\
490.1(+2) \\
979.6(+1) \\
490.3(+2) \\
490.2(+2) \\
490.3(+3) \\
\end{array}$ & $\begin{array}{l}120.1 \\
120.1 \\
- \\
761.5 \\
761.5 \\
761.5 \\
648.4 \\
\end{array}$ & $\begin{array}{l}a_{1}{ }^{+} \\
a_{1}{ }^{+} \\
- \\
y_{6}{ }^{+} \\
y_{6}{ }^{+} \\
y_{6}{ }^{+} \\
y_{5}\end{array}$ & $\begin{array}{l}648.4 \\
648.4 \\
- \\
648.4^{*} \\
648.4 \\
219.2 \\
219.1 \\
\end{array}$ & $\begin{array}{l}y_{5^{+}} \\
y_{5}{ }^{+} \\
- \\
y_{5} 5^{+} \\
y_{5} 5^{+} \\
b_{2} 2^{+} \\
b_{2}{ }^{+}\end{array}$ & $\begin{array}{l}- \\
- \\
- \\
- \\
- \\
423.3 \\
- \\
-\end{array}$ & $\begin{array}{l}- \\
- \\
- \\
- \\
- \\
y_{3}^{+} \\
- \\
-\end{array}$ & $\begin{array}{l}\text { Heick et al., 2011a } \\
\text { Heick et al., 2011b } \\
\text { Losito et al.,. 2013 } \\
\text { Lutter et al., } 2011 \\
\text { Monaci et al., } 2013 \\
\text { Gu et al., } 2018 \\
\text { Ke et al., } 2017 \\
\text { Qi et al. } 2019 \\
\end{array}$ \\
\hline \multirow[t]{4}{*}{$\begin{array}{l}\text { Bos d } 5-\beta- \\
\text { Lactoglobulin }\end{array}$} & $\begin{array}{l}\text { TPEVDDEALEK } \\
\text { Bos d } 5.0101\end{array}$ & $\begin{array}{l}\text { Bos taurus (9913) } \\
\text { Bubalus bubalis (89462) } \\
\text { Bos mutus (72004) }\end{array}$ & $\begin{array}{l}\text { QqQ } \\
\text { Dual LIT } \\
\text { QqQ } \\
\text { QqQ } \\
\text { QqQ-ToF } \\
\text { QqQ } \\
\text { Q-Orbitrap } \\
\text { QqQ } \\
\end{array}$ & $\begin{array}{l}623.3(+2) \\
623.3(+2) \\
623.3(+2) \\
623.3(+2) \\
623.3(+2) \\
623.3(+2) \\
623.3(+2) \\
623.3(+2) \\
\end{array}$ & $\begin{array}{l}918.4 \\
572.8 \\
572.8 \\
- \\
1048.2 \\
572.8 \\
- \\
572.8 \\
\end{array}$ & $\begin{array}{l}\mathrm{y}_{8}^{+} \\
\mathrm{y}_{10^{++}} \\
\mathrm{y}_{100^{++}} \\
- \\
\mathrm{y}_{9^{+}} \\
\mathrm{y}_{10^{++}} \\
- \\
\mathrm{y}_{110^{++}}\end{array}$ & $\begin{array}{l}819.4^{*} \\
819.4 \\
819.4 \\
- \\
199.2 \\
819.4 \\
- \\
819.4 \\
\end{array}$ & $\begin{array}{l}y_{7^{+}} \\
y_{7^{+}} \\
y_{7^{+}} \\
- \\
b_{2}{ }^{+} \\
y_{7^{+}} \\
- \\
y_{7^{+}}\end{array}$ & $\begin{array}{l}- \\
918.4 \\
- \\
918.4 \\
- \\
\end{array}$ & $\begin{array}{l}- \\
- \\
\mathrm{y}_{8}^{+} \\
- \\
\mathrm{y}_{8}^{+} \\
- \\
-\end{array}$ & $\begin{array}{l}\text { Lutter et al., } 2011 \\
\text { Monaci et al., } 2014 \\
\text { Parker et al., } 2015 \\
\text { Yang et al., } 2014 \\
\text { Ji et al. } 2017 \\
\text { Boo et al., } 2018 \\
\text { Pilolli et al., } 2018 \\
\text { New et al., } 2018 \\
\end{array}$ \\
\hline & $\begin{array}{l}\text { VLVLDTDYK } \\
\text { Bos d } 5.0101\end{array}$ & $\begin{array}{l}\text { Bos taurus (9913) } \\
\text { Bubalus bubalis (89462) } \\
\text { Capra hircus (9925) } \\
\text { Ovis aries musimon (9938) } \\
\text { Ovis aries (9940) } \\
\text { Rangifer tarandus tarandus } \\
\text { (86329) } \\
\text { Bos indicus (9915) } \\
\text { Bos grunniens (30521) } \\
\text { Bos motus (72004) } \\
\text { Ovis sp. (9939) }\end{array}$ & $\begin{array}{l}\mathrm{QqQ} \\
\mathrm{QqQ} \\
\mathrm{QqQ} \\
\mathrm{QqQ} \\
\mathrm{QqQ} \\
\mathrm{QqQ}\end{array}$ & $\begin{array}{l}533.6(+2) \\
533.3(+2) \\
533.3(+2) \\
533.3(+2) \\
533.3(+2) \\
533.3(+2)\end{array}$ & $\begin{array}{l}853.4^{*} \\
853.4 \\
853.4 \\
853.4 \\
853.4\end{array}$ & $\begin{array}{l}- \\
y_{7^{+}} \\
y_{7^{+}} \\
y_{7^{+}} \\
y_{7^{+}} \\
y_{7^{+}}\end{array}$ & $\begin{array}{l}754.4 \\
754.4 \\
754.4 \\
754.4 \\
754.4\end{array}$ & $\begin{array}{l} \\
y_{6}^{+} \\
y_{6}^{+} \\
y_{6}^{+} \\
y_{6}^{+} \\
y_{6}^{+}\end{array}$ & $\begin{array}{l}- \\
641.3 \\
641.3 \\
641.3 \\
-\end{array}$ & $\begin{array}{l}- \\
y_{5}^{+} \\
y_{5}+ \\
y_{5}^{+}\end{array}$ & $\begin{array}{l}\text { Figeys et al., } 1996 \\
\text { Lutter et al., } 2011 \\
\text { Parker et al., 2015 } \\
\text { Planque et al., 2016 } \\
\text { Planque et al., } 2017 \mathrm{~b} \\
\text { Planque et al., } 2019\end{array}$ \\
\hline & $\begin{array}{l}\text { VYVEELKPTPEGDLEILLQK } \\
\text { Bos d } 5.0101\end{array}$ & $\begin{array}{l}\text { Bos taurus (9913) } \\
\text { Bubalus bubalis (89462) } \\
\text { Bos grunniens (30521) } \\
\text { Bos motus (72004) }\end{array}$ & $\begin{array}{l}\mathrm{QqQ} \\
\mathrm{QqQ} \\
\mathrm{QqQ}\end{array}$ & $\begin{array}{l}771.5(+3) \\
771.8(+3) \\
771.8(+3)\end{array}$ & $\begin{array}{l}\overline{9} \\
912.0\end{array}$ & $\begin{array}{l}- \\
y_{16} 6^{++} \\
y_{16} 6^{++}\end{array}$ & $\begin{array}{l}790.9 \\
790.9\end{array}$ & $\begin{array}{l}-\bar{y} \\
y_{14^{++}} \\
y_{14}++\end{array}$ & $\begin{array}{l}- \\
627.9 \\
627.9\end{array}$ & $\begin{array}{l}-\bar{x} \\
y_{111^{++}} \\
y_{11}\end{array}$ & $\begin{array}{l}\text { Figeys et al., } 1996 \\
\text { Planque et al., } 2016 \\
\text { Planque et al., } 2017 \mathrm{~b}\end{array}$ \\
\hline & $\begin{array}{l}\text { LSFNPTQLEEQCEHI } \\
\text { Bos d } 5.0101\end{array}$ & $\begin{array}{l}\text { Bos taurus (9913) } \\
\text { Bubalus bubalis (89462) }\end{array}$ & $\begin{array}{l}\mathrm{QqQ} \\
\mathrm{QqQ} \\
\mathrm{QqQ} \\
\mathrm{QqQ} \\
\mathrm{QqQ} \\
\mathrm{QqQ} \\
\end{array}$ & $\begin{array}{l}858.4(+2) \\
858.4(+2) \\
858.4(+2) \\
858.4(+2) \\
858.6(+2) \\
858.4(+2) \\
\end{array}$ & $\begin{array}{l}928.4 \\
928.4 \\
1254.6 \\
928.4 \\
462.2^{*} \\
1254.6 \\
\end{array}$ & 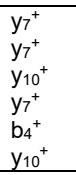 & $\begin{array}{l}815.3 \\
1254.6 \\
815.3 \\
627.8 \\
685.1 \\
627.8 \\
\end{array}$ & $\begin{array}{l}\mathrm{y}_{6^{+}} \\
\mathrm{y}_{10^{+}} \\
\mathrm{y}_{6} 6^{+} \\
\mathrm{y}_{10^{++}} \\
\mathrm{y}_{11^{++}} \\
\mathrm{y}_{10^{++}}\end{array}$ & $\begin{array}{l}627.8 \\
627.8 \\
627.8 \\
- \\
-\end{array}$ & 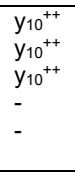 & $\begin{array}{l}\text { Parker et al., } 2015 \\
\text { Planque et al., } 2016 \\
\text { Planque et al., 2017b } \\
\text { Boo et al., 2018 } \\
\text { Ke et al., } 2017 \\
\text { Planque et al., } 2019 \\
\end{array}$ \\
\hline $\begin{array}{l}\text { Gal d } 2 \text { - } \\
\text { Ovalbumin }\end{array}$ & $\begin{array}{l}\text { GGLEPINFQTAADQAR } \\
\text { Gal d } 2.0101\end{array}$ & $\begin{array}{l}\text { Gallus gallus (9031) } \\
\text { Alcaligenes yylosoxydans } \\
\text { xylosoxydans (85698) }\end{array}$ & $\begin{array}{l}\text { Q-ToF } \\
\text { LIT } \\
\text { Orbitrap } \\
\text { Dual LIT } \\
\text { QqQ } \\
\text { Dual LIT / Orbitrap }\end{array}$ & $\begin{array}{l} \\
844.4(+2) \\
844.4(+2) \\
844.4(+2) \\
844.4(+2) \\
844.4(+2) \\
\end{array}$ & $\begin{array}{l}666.3 \\
- \\
666.3 \\
1007.5 \\
666.3 \\
\end{array}$ & $\begin{array}{l}-\overline{y_{12}++} \\
-y_{12}^{++} \\
y_{9}{ }^{+} \\
y_{112^{++}}\end{array}$ & $\begin{array}{l}1331.7 \\
- \\
1121.5 \\
1121.5 \\
1331.7 \\
\end{array}$ & $\begin{array}{l} \\
y_{12}^{+} \\
y_{110^{+}}^{+} \\
y_{10} \\
y_{12}^{+}\end{array}$ & $\begin{array}{l}- \\
- \\
- \\
860.4\end{array}$ & $\begin{array}{l}-\overline{-} \\
\overline{-} \\
- \\
\mathrm{y}_{8}^{+}\end{array}$ & $\begin{array}{l}\text { Azarnia et al., } 2013 \\
\text { Mattarozzi et al., } 2014 \\
\text { Monaci et al., } 2013 \\
\text { Monaci et al., } 2014 \\
\text { Parker et al., } 2015 \\
\text { Pilolli et al., 2014 }\end{array}$ \\
\hline
\end{tabular}




\begin{tabular}{|c|c|c|c|c|c|c|c|c|c|c|c|}
\hline & & & $\begin{array}{l}\text { Dual LIT } \\
\text { QqQ } \\
\text { Q-ToF } \\
\text { QqQ } \\
\text { QqQ } \\
\text { QqQ } \\
\text { Dual LIT } \\
\text { QqQ } \\
\text { Q-Orbitrap } \\
\text { Dual LIT } \\
\text { QqQ }\end{array}$ & $\begin{array}{l}844.4(+2) \\
844.4(+2) \\
844.4(+2) \\
844.4(+2) \\
844.4(+2) \\
844.4(+2) \\
844.4(+2) \\
844.4(+2) \\
844.4(+2) \\
844.4(+2) \\
844.4(+2) \\
\end{array}$ & $\begin{array}{l}666.3 \\
666.3 \\
- \\
666.3 \\
666.3 \\
1007.5 \\
666.3 \\
666.3 \\
-666.3 \\
666.3 \\
\end{array}$ & $\begin{array}{l}y_{122^{++}} \\
y_{12} \\
y_{12^{++}} \\
y_{122^{++}} \\
y_{9}^{+} \\
y_{12^{++}} \\
y_{1} 2^{++} \\
y_{122^{++}} \\
y_{122^{++}}\end{array}$ & $\begin{array}{l}1121.5 \\
1121.5 \\
- \\
- \\
1121.5 \\
1121.5 \\
1121.5 \\
1121.5 \\
-1121.5 \\
1121.5 \\
\end{array}$ & $\begin{array}{l}y_{10^{+}} \\
y_{10^{+}} \\
- \\
- \\
y_{10^{+}} \\
y_{10^{+}} \\
y_{10^{+}} \\
y_{10} \\
- \\
y_{11}+ \\
y_{11}+\end{array}$ & $\begin{array}{l}732.4 \\
1331.7 \\
- \\
1331.7 \\
860.4 \\
732.4 \\
- \\
1331.7\end{array}$ & $\begin{array}{l}y_{7^{+}} \\
y_{12}^{+} \\
- \\
- \\
y_{122^{+}} \\
y_{8} \\
y_{7^{+}}^{+} \\
- \\
- \\
y_{12}{ }^{+}\end{array}$ & $\begin{array}{l}\text { Pilolli et al., 2017a } \\
\text { Planque et al., 2016 } \\
\text { Tolin et al., 2012b } \\
\text { Planque et al., 2017a } \\
\text { Planque et al., 2017b } \\
\text { Boo et al., 2018 } \\
\text { Pilolli et al., 2017b } \\
\text { New et al., 2018 } \\
\text { Pilolli et al., 2018 } \\
\text { De Angelis et al., 2017b } \\
\text { Planque et al., 2019 }\end{array}$ \\
\hline & $\begin{array}{l}\text { HIATNAVLFFGR } \\
\text { Gal d } 2.0101\end{array}$ & $\begin{array}{l}\text { Gallus gallus (9031) } \\
\text { Alcaligenes xylosoxydans } \\
\text { xylosoxydans (85698) }\end{array}$ & $\begin{array}{l}\text { Q-ToF } \\
\text { QqQ } \\
\text { QqQ } \\
\text { Orbitrap } \\
\text { QqQ } \\
\text { Q-ToF } \\
\end{array}$ & $\begin{array}{l}673.4(+2) \\
673.4(+2) \\
673.4(+2) \\
449.3(+3) \\
-\end{array}$ & $\begin{array}{l}1095.6 \\
1095.6 \\
- \\
639.4^{*} \\
\end{array}$ & $\begin{array}{l} \\
y_{10^{+}} \\
y_{10^{+}} \\
y_{5}^{+} \\
\end{array}$ & $\begin{array}{l}- \\
223.2 \\
223.2 \\
- \\
526.3 \\
-\end{array}$ & $\begin{array}{l}- \\
\mathrm{a}_{2}^{+} \\
\mathrm{a}_{2}{ }^{+} \\
\mathrm{y}_{4}^{+} \\
-\end{array}$ & $\begin{array}{l}- \\
- \\
- \\
608.3 \\
-\end{array}$ & $\begin{array}{l}- \\
- \\
- \\
- \\
\mathrm{b}_{6}^{+} \\
-\end{array}$ & $\begin{array}{l}\text { Azarnia et al., 2013 } \\
\text { Heick et al.. 2011a } \\
\text { Heick et al., 2011b } \\
\text { Monaci et al., 2013 } \\
\text { Parker et al., 2015 } \\
\text { Tolin et al., 2012 }\end{array}$ \\
\hline & $\begin{array}{l}\text { ISQAVHAAHAEINEAGR } \\
\text { Gal d } 2.0101\end{array}$ & $\begin{array}{l}\text { Gallus gallus (9031) } \\
\text { Coturnix japonica (93934) } \\
\text { Alcaligenes xylosoxydans } \\
\text { xylosoxydans (85698) }\end{array}$ & $\begin{array}{l}\text { Q-ToF } \\
\text { Orbitrap } \\
\text { QqQ } \\
\text { QqQ } \\
\end{array}$ & $\begin{array}{l}887.4(+2) \\
887.5(+2) \\
887.5(+2) \\
\end{array}$ & $\begin{array}{l}- \\
1138.6 \\
1138.6\end{array}$ & $\begin{array}{l}- \\
\overline{y_{11}}+ \\
y_{11}+\end{array}$ & $\begin{array}{l}- \\
1067.5 \\
1067.5 \\
\end{array}$ & $\begin{array}{l}- \\
y_{10}+ \\
y_{10}+\end{array}$ & $\begin{array}{l}-\overline{-} \\
996.5 \\
996.5\end{array}$ & $\begin{array}{l}-\bar{c} \\
y_{9}^{+} \\
y_{9}{ }^{+}\end{array}$ & $\begin{array}{l}\text { Azarnia et al., } 2013 \\
\text { Monaci et al., } 2013 \\
\text { Planque et al., } 2016 \\
\text { Planque et al., } 2017 \mathrm{~b} \\
\end{array}$ \\
\hline \multirow[t]{2}{*}{ 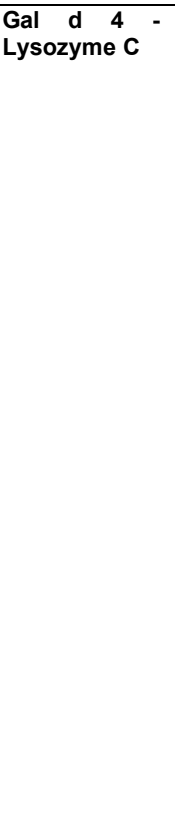 } & $\begin{array}{l}\text { FESNFNTQATNR } \\
\text { Gal d } 4.0101\end{array}$ & $\begin{array}{l}\text { Gallus gallus (9031) } \\
\text { Coturnix japanica (93934) } \\
\text { Rattus norvegicus (10116) } \\
\text { Gallus lafayetii (9032) } \\
\text { Gallus sonneratii (9033) }\end{array}$ & $\begin{array}{l}\text { QqQ } \\
\text { Orbitrap } \\
\text { QqQ } \\
\text { QqQ } \\
\text { QqQ } \\
\end{array}$ & $\begin{array}{l}714.8(+2) \\
714.8(+2) \\
714.8(+2) \\
714.8(+2) \\
714.8(+2) \\
\end{array}$ & $\begin{array}{l}277.1 \\
- \\
1152.5 \\
589.3 \\
1152.5 \\
\end{array}$ & $\begin{array}{l}\mathrm{b}_{2}^{+} \\
- \\
\mathrm{y}_{10^{+}} \\
\mathrm{y}_{5}^{+} \\
\mathrm{y}_{10^{+}}\end{array}$ & $\begin{array}{l}- \\
951.5 \\
690.4 \\
951.5 \\
\end{array}$ & $\begin{array}{l}- \\
- \\
y_{8}^{+} \\
y_{6}^{+} \\
y_{8}^{+}\end{array}$ & $\begin{array}{l}- \\
804.4 \\
- \\
804.4 \\
\end{array}$ & $\begin{array}{l}- \\
y_{7}^{+} \\
y_{7}^{+} \\
\end{array}$ & $\begin{array}{l}\text { Cryar et al., } 2013 \\
\text { Monaci et al., } 2013 \\
\text { Parker et al., } 2015 \\
\text { Pilolli et al., } 2014 \\
\text { Boo et al., } 2018 \\
\end{array}$ \\
\hline & $\begin{array}{l}\text { NTDGSTDYGILQINSR } \\
\text { Gal d } 4.0101\end{array}$ & $\begin{array}{l}\text { Gallus gallus (90031) } \\
\text { Anas platyrhynchos (8839) } \\
\text { Catreus wallichii (9085) } \\
\text { Chrysolophus amherstiae (9088) } \\
\text { Coturnix japonica (93934) } \\
\text { Lophophorus impejanus (9040) } \\
\text { Lophura leucomelanos (140445) } \\
\text { Meleagris gallopavo (9103) } \\
\text { Pavo cristatus (9049) } \\
\text { Phasianus colchicus colchicus } \\
\text { (9057) } \\
\text { Phasianus versicolor (9055) } \\
\text { Syrmaticus soemmerringii } \\
\text { (9067) } \\
\text { Syrmaticus reevesii (9066) } \\
\text { Tragopan satyra (9070) } \\
\text { Tragopan temminckii (9071) } \\
\text { Rattus norvegicus (10116) } \\
\text { Pavo cristatus (9049) } \\
\text { Phasianus colchicus (9054) } \\
\text { Phasianus colchicus colchicus } \\
\text { (9057) } \\
\text { Gallus lafayetii (9032) } \\
\text { Gallus sonneratii (903) } \\
\text { Alopochen aegyptiaca (30382) }\end{array}$ & $\begin{array}{l}\text { Orbitrap } \\
\text { QqQ } \\
\text { Dual LIT / Orbitrap } \\
\text { Dual LIT }\end{array}$ & $\begin{array}{l}877.4(+2) \\
585.3(+3) \\
877.4(+2) \\
877.4(+2)\end{array}$ & $\begin{array}{l}489.3 \\
489.3 \\
489.3\end{array}$ & $\begin{array}{l}- \\
y_{4}^{+} \\
y_{4}^{+} \\
y_{4}^{+}\end{array}$ & $\begin{array}{l}617.3 \\
617.3 \\
617.3\end{array}$ & $\begin{array}{l}y_{5}^{+} \\
y_{5}^{+} \\
y_{5}\end{array}$ & $\begin{array}{l}-730.4 \\
- \\
730.4\end{array}$ & $\begin{array}{l}y_{6}^{+} \\
y_{6}^{+}\end{array}$ & $\begin{array}{l}\text { Monaci et al., } 2013 \\
\text { Parker et al., } 2015 \\
\text { Pilolli et al., } 2014 \\
\text { De Angelis et al., 2017b }\end{array}$ \\
\hline \multirow[t]{2}{*}{ Vitellogenin-1 } & $\begin{array}{l}\text { YLLDLLPAAASHR } \\
\text { (lipovitellin-1 chain) }\end{array}$ & Gallus gallus (9031) & $\begin{array}{l}\mathrm{QqQ} \\
\mathrm{QqQ} \\
\mathrm{QqQ} \\
\mathrm{QqQ}\end{array}$ & $\begin{array}{l}480.6(+3) \\
480.6(+3) \\
480.6(+3) \\
480.6(+3)\end{array}$ & $\begin{array}{l}709.4 \\
709.4 \\
709.4 \\
709.4\end{array}$ & $\begin{array}{l}y_{7}^{+} \\
y_{7}^{+} \\
y_{7}^{+} \\
y_{7}^{+}\end{array}$ & $\begin{array}{l}582.3 \\
582.3 \\
355.2 \\
582.3\end{array}$ & $\begin{array}{l}y_{11^{++}} \\
y_{11^{++}} \\
y_{7}^{++} \\
y_{11} 1^{++}\end{array}$ & $\begin{array}{l}355.2 \\
355.2 \\
-\end{array}$ & $\begin{array}{l}y_{7^{7+}} \\
y_{7}\end{array}$ & $\begin{array}{l}\text { Planque et al., } 2016 \\
\text { Planque et al., 2017b } \\
\text { New et al., 2018 } \\
\text { Planque et al., } 2019\end{array}$ \\
\hline & $\begin{array}{l}\text { ALLLSEIR } \\
\text { (lipovitellin-1 chain) }\end{array}$ & $\begin{array}{l}\text { Gallus gallus (9031) } \\
\text { Fundulus heteroclitus (8078) }\end{array}$ & $\mathrm{QqQ}$ & $457.8(+2)$ & 617.4 & $\mathrm{ys}^{+}$ & 730.5 & $y_{6}{ }^{+}$ & - & - & New et al., 2018 \\
\hline
\end{tabular}




\begin{tabular}{|c|c|c|c|c|c|c|c|c|c|c|c|}
\hline & & $\begin{array}{l}\text { Galdieria sulphuraria }(130081) \\
\text { Nicrophorus } \\
\text { (110193) }\end{array}$ & & & & & & & & & \\
\hline \multirow[t]{3}{*}{ Vitellogenin-2 } & $\begin{array}{l}\text { NIPFAEYPTYK } \\
\text { (lipovitellin-1 chain) }\end{array}$ & $\begin{array}{l}\text { Gallus gallus (9031) } \\
\text { Larus argentatus (35669) } \\
\text { Anas platyrhynchos (8839) } \\
\text { Cuculus canorus (55661) } \\
\text { Buceros rhinoceros silvestris } \\
\text { (175836) } \\
\text { Charadrius vociferus (50402) } \\
\text { Merops nubicus (57421) } \\
\text { Pelecanus crispus (36300) } \\
\text { Mesitornis unicolor (54374) } \\
\text { Colinus virginianus (9014) } \\
\text { Meleagris gallopavo (9103) } \\
\text { Callipepla squamata (9009) } \\
\text { Haliaeetus albicilla (8969) } \\
\text { Mesitornis unicolor (54374) }\end{array}$ & $\begin{array}{l}\mathrm{QqQ} \\
\mathrm{QqQ} \\
\mathrm{QqQ}\end{array}$ & $\begin{array}{l}671.8(+2) \\
671.8(+2) \\
671.8(+2)\end{array}$ & $\begin{array}{l}1115.5 \\
1115.5 \\
1115.5\end{array}$ & $\begin{array}{l}\mathrm{yg}_{9^{+}} \\
\mathrm{yg}^{+} \\
\mathrm{y}_{9^{+}}\end{array}$ & $\begin{array}{l}508.3 \\
508.3 \\
558.3\end{array}$ & $\begin{array}{l}y_{4}{ }^{+} \\
y_{4}{ }^{+} \\
y_{9}^{++}\end{array}$ & $\begin{array}{l}558.3 \\
558.3 \\
-\end{array}$ & $\begin{array}{l}\mathrm{yg}_{9}++ \\
\mathrm{y}_{9}\end{array}$ & $\begin{array}{l}\text { Planque et al., } 2016 \\
\text { Planque et al., } 2017 \mathrm{~b} \\
\text { Planque et al., } 2019\end{array}$ \\
\hline & $\begin{array}{l}\text { NIGELGVEK } \\
\text { (lipovitellin-1 chain) }\end{array}$ & $\begin{array}{l}\text { Gallus gallus (9031) } \\
\text { Larus argentatus (35669) } \\
\text { Anas platyrhynchos (8839) } \\
\text { Nipponia nippon (128390) } \\
\text { Calypte anna (9244) } \\
\text { Nestor notabilis (176057) } \\
\text { Buceros rhinoceros silvestris } \\
\text { (175836) } \\
\text { Charadrius vociferus (50402) } \\
\text { Pelecanus crispus (36300) } \\
\text { Merops nubicus (57421) } \\
\text { Aptenodytes forsteri (9233) } \\
\text { Patagieenas fasciata monilis } \\
\text { (372326) } \\
\text { Phalacrocorax carbo (9209) } \\
\text { Antrostomus carolinensis } \\
\text { (279965) } \\
\text { Chlamydotis macqueenii } \\
\text { (187382) } \\
\text { Opisthocomus hoazin (30419) }\end{array}$ & $\begin{array}{l}\mathrm{QqQ} \\
\mathrm{QqQ} \\
\mathrm{QqQ}\end{array}$ & $\begin{array}{l}479.8(+2) \\
479.8(+2) \\
479.8(+2)\end{array}$ & $\begin{array}{l}731.4 \\
731.4 \\
731.4\end{array}$ & $\begin{array}{l}y_{7^{+}}^{+} \\
y_{7^{+}} \\
y_{7}^{+}\end{array}$ & $\begin{array}{l}674.4 \\
674.4 \\
228.1\end{array}$ & $\begin{array}{l}y_{6^{+}}{ }^{+} \\
y_{6}{ }^{+} \\
b_{2}{ }^{+}\end{array}$ & $\begin{array}{l}545.3 \\
545.3 \\
-\end{array}$ & $\begin{array}{l}y_{5}^{+} \\
y_{5}^{+} \\
-\end{array}$ & $\begin{array}{l}\text { Planque et al., } 2016 \\
\text { Planque et al., } 2017 \mathrm{~b} \\
\text { New et al., } 2018\end{array}$ \\
\hline & $\begin{array}{l}\text { LPLSLPVGPR } \\
\text { (lipovitellin-2 chain) }\end{array}$ & $\begin{array}{l}\text { Gallus gallus (9031) } \\
\text { Hydroprogne caspia (425641) } \\
\text { Taeniopygia guttata (59729) } \\
\text { Sterna hirundo (108405) } \\
\text { Falco sparverius (56350) } \\
\text { Larus argentatus (35669) } \\
\text { Meleagris gallopavo (9103) } \\
\text { Nipponia nippon (128390) } \\
\text { Nestor notabilis (176057) } \\
\text { Callipepla squamata (9009) } \\
\text { Phaethon lepturus (97097) } \\
\text { Falco sparverius (56350) } \\
\text { Buceros rhinoceros silvestris } \\
\text { (175836) } \\
\text { Charadrius vociferous (50402) } \\
\text { Amazona aestiva (1290) } \\
\text { Ficedula albicollis (59894) } \\
\text { Merops nubicus (57421) } \\
\text { Aptenodytes forsteri (9233) } \\
\text { Hydroprogne caspia (425641) } \\
\end{array}$ & QqQ & $524.8(+2)$ & 468.3 & $\mathrm{yg}_{9}^{++}$ & 725.4 & $\mathrm{y}_{7}^{+}$ & - & - & New et al., 2018 \\
\hline
\end{tabular}




\begin{tabular}{|c|c|c|c|c|c|c|c|c|c|c|c|}
\hline & & $\begin{array}{l}\text { Patagioenas fasciata monilis } \\
\text { (372326) } \\
\text { Mesitornis unicolor (54374) } \\
\text { Balearica regulorum gibbericeps } \\
\text { (100784) } \\
\text { Phalacrocorax carbo (9209) } \\
\text { Antrostomus carolinensis } \\
\text { (279965) } \\
\text { Chlamydotis macqueenii } \\
\text { (187382) } \\
\text { Colinus virginianus (9014) } \\
\text { Opisthocomus hoazin (30419) }\end{array}$ & & & & & & & & & \\
\hline \multirow[t]{3}{*}{$\begin{array}{l}\text { Ara h } \quad 1 \quad \text { । } \\
\text { Cupin } \\
\text { (Vicillin-Type, } \\
\text { 7S Globulin) }\end{array}$} & $\begin{array}{l}\text { DLAFPGSGEQVEK } \\
\text { Ara h } 1.0101 \text { (clone P41B) } \\
\text { Ara h } 1 \text { - clone P17 }\end{array}$ & $\begin{array}{l}\text { Arachis hypogaea (3818) } \\
\text { Arachis duranensis (130453) }\end{array}$ & $\begin{array}{l}\text { Q-ToF } \\
\text { QqQ } \\
\text { QqQ } \\
\text { QqQ } \\
\text { QqQ } \\
\text { QqQ } \\
\text { QqQ } \\
\text { QqQ } \\
\text { QqQ } \\
\end{array}$ & $\begin{array}{l}688.9(+2) \\
688.8(+2) \\
688.8(+2) \\
688.8(+2) \\
688.8(+2) \\
688.8(+2) \\
688.9(+2) \\
688.8(+2) \\
688.8(+2) \\
\end{array}$ & $\begin{array}{l} \\
930.6 \\
930.6 \\
930.5 \\
930.5 \\
930.5 \\
930.5 \\
930.5 \\
929.4 \\
\end{array}$ & 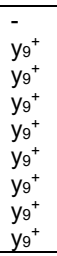 & $\begin{array}{l}300.2 \\
300.2 \\
833.4 \\
833.4 \\
833.4 \\
300.2 \\
300.2 \\
447.2 \\
\end{array}$ & $\begin{array}{l}- \\
a_{3}{ }^{+} \\
a_{3}{ }^{+} \\
y_{8} 8^{+} \\
y_{8}{ }^{+} \\
y_{8} 8^{+} \\
b_{3}{ }^{+} \\
b_{3}{ }^{+} \\
b_{4}{ }^{+}\end{array}$ & $\begin{array}{l}- \\
- \\
- \\
1077.5 \\
776.4 \\
776.4 \\
229.1 \\
- \\
- \\
\end{array}$ & $\begin{array}{l}- \\
- \\
- \\
y_{110^{+}} \\
y_{7}^{+} \\
y_{7}^{+} \\
b_{2}^{+} \\
- \\
- \\
\end{array}$ & $\begin{array}{l}\text { Chassaigne et al., } 2007 \\
\text { Heick et al., 2011a } \\
\text { Heick et al., 2011b } \\
\text { Pedreschi et al., 2012 } \\
\text { Sayers et al., } 2016 \\
\text { Sayers et al., } 2018 \\
\text { Shefcheck et al., } 2006 \\
\text { New et al., } 2018 \\
\text { Zhang et al., } 2019 \\
\end{array}$ \\
\hline & $\begin{array}{l}\text { VLLEENAGGEQEER } \\
\text { Ara h } 1.0101 \text { (clone P41B) } \\
\text { Ara h } 1 \text { - clone P17 }\end{array}$ & $\begin{array}{l}\text { Arachis hypogaea (3818) } \\
\text { Arachis duranensis (130453) }\end{array}$ & $\begin{array}{l}\text { QqQ } \\
\text { QqQ } \\
\text { Dual LIT } \\
\text { QqQ } \\
\text { QqQ } \\
\text { Q-Orbitrap } \\
\text { QqQ } \\
\text { Q-ToF } \\
\text { LIT-Orbitrap }\end{array}$ & $\begin{array}{l}786.9(+2) \\
786.9(+2) \\
786.9(+2) \\
786.9(+2) \\
786.9(+2) \\
786.8(+2) \\
786.9(+2) \\
786.9(+2) \\
786.9(+2) \\
\end{array}$ & $\begin{array}{l}804.3 \\
804.3 \\
804.3 \\
804.3 \\
804.4 \\
-804.4 \\
- \\
- \\
\end{array}$ & $\begin{array}{l}y_{7^{+}} \\
y_{7^{+}} \\
y_{7^{+}} \\
y_{7^{+}} \\
y_{7}^{+} \\
y_{7^{+}} \\
- \\
-\end{array}$ & $\begin{array}{l}875.4 \\
875.4 \\
875.4 \\
875.4 \\
213.2 \\
- \\
11118.5 \\
- \\
\end{array}$ & $\begin{array}{l}- \\
y_{8}^{+} \\
y_{8}^{+} \\
y_{8}^{+} \\
b_{2}^{+} \\
- \\
y_{10^{+}}^{+} \\
- \\
-\end{array}$ & $\begin{array}{l}989.4 \\
989.4 \\
680.8 \\
989.4 \\
989.4 \\
- \\
- \\
- \\
-\end{array}$ & $\begin{array}{l}\mathrm{yg}_{9^{+}} \\
\mathrm{y}_{9^{+}} \\
\mathrm{y}_{12^{++}} \\
\mathrm{y}_{9^{+}} \\
\mathrm{y}_{9^{+}} \\
- \\
- \\
- \\
- \\
\end{array}$ & $\begin{array}{l}\text { Pedreschi et al., 2012 } \\
\text { Sayers et al., 2016 } \\
\text { Pilolli et al., 2017a } \\
\text { Sayers et al., 2018 } \\
\text { Shefcheck et al., } 2006 \\
\text { Pilolli et al., 2018 } \\
\text { New et al., } 2018 \\
\text { Chassaigne et al., } 2007 \\
\text { Korte et al., 2016 } \\
\end{array}$ \\
\hline & $\begin{array}{l}\text { GTGNLELVAVR } \\
\text { Ara h } 1.0101 \text { (clone P41B) } \\
\text { Ara h } 1 \text { - clone P17 }\end{array}$ & $\begin{array}{l}\text { Arachis hypogaea (3818) } \\
\text { Arachis duranensis (130453) }\end{array}$ & $\begin{array}{l}\mathrm{QqQ} \\
\mathrm{QqQ} \\
\mathrm{QqQ} \\
\mathrm{QqQ} \\
\mathrm{QqQ} \\
\mathrm{Q} \text {-Orbitrap }\end{array}$ & $\begin{array}{l}564.4(+2) \\
564.4(+2) \\
564.8(+2) \\
564.8(+2) \\
564.8(+2) \\
564.8(+2)\end{array}$ & $\begin{array}{l}686.6 \\
686.6 \\
686.4 \\
686.4 \\
686.4 \\
-\end{array}$ & $\begin{array}{l}y_{6}{ }^{+} \\
y_{6}{ }^{+} \\
y_{6}{ }^{+} \\
y_{6}{ }^{+} \\
y_{6}{ }^{+}\end{array}$ & $\begin{array}{l}557.5 \\
557.5 \\
557.4 \\
557.4 \\
557.4 \\
-\end{array}$ & $\begin{array}{l}y_{5}{ }^{+} \\
y_{5}{ }^{+} \\
y_{5}{ }^{+} \\
y_{5}{ }^{+} \\
y_{5}{ }^{+}\end{array}$ & $\begin{array}{l}- \\
799.5 \\
444.3 \\
799.5 \\
-\end{array}$ & $\begin{array}{l}- \\
y_{7^{+}} \\
y_{4} \\
y_{7^{+}}\end{array}$ & $\begin{array}{l}\text { Heick et al., 2011a } \\
\text { Heick et al., 2011b } \\
\text { Parker et al., 2015 } \\
\text { Gu et al., 2018 } \\
\text { Boo et al., 2018 } \\
\text { Pilolli et al., } 2018\end{array}$ \\
\hline \multirow[t]{2}{*}{$\begin{array}{l}\text { Ara } h 2{ }^{-} \\
\text {Conglutin }\left(2 S^{-}\right. \\
\text {Albumin) }\end{array}$} & $\begin{array}{l}\text { CCNELNEFENNQR } \\
\text { Ara } h 2.0101, \\
\text { Ara } h 2.0201 \\
\text { Ara } h 2.0202\end{array}$ & $\begin{array}{l}\text { Arachis ipaensis (130454) } \\
\text { Arachis hypogaea (3818) } \\
\text { Arachis duranensis (130453) }\end{array}$ & $\begin{array}{l}\mathrm{QqQ} \\
\mathrm{QqQ} \\
\mathrm{QqQ} \\
\mathrm{QqQ} \\
\mathrm{QqQ} \\
\mathrm{QqQ} \\
\mathrm{QqQ} \\
\end{array}$ & $\begin{array}{l}807.0(+2) \\
576.2(+3) \\
863.8(+2) \\
863.9(+2) \\
863.8(+2) \\
863.8(+2) \\
\end{array}$ & $\begin{array}{l}1050.5 \\
\\
920.3 \\
807.4 \\
1163.5 \\
1163.5 \\
1163.5 \\
\end{array}$ & $\begin{array}{l}\mathrm{b}_{7}{ }^{+} \\
y_{6}{ }^{+} \\
y_{9}{ }^{+} \\
y_{9^{+}} \\
y_{9^{+}}\end{array}$ & $\begin{array}{l}807.4 \\
1050.5 \\
1050.5 \\
1050.5 \\
1050.5 \\
\end{array}$ & $\begin{array}{l}- \\
y_{6}^{+} \\
y_{8}^{+} \\
y_{8}^{+} \\
y_{8}^{+} \\
y_{8}^{+}\end{array}$ & $\begin{array}{l}660.3 \\
660.3 \\
936.4 \\
936.4 \\
936.4 \\
\end{array}$ & $\begin{array}{l}y_{5}{ }^{+} \\
y_{5}{ }^{+} \\
y_{7}^{+} \\
y_{7}^{+} \\
y_{7}^{+} \\
\end{array}$ & $\begin{array}{l}\text { Careri et al., } 2007 \\
\text { Careri et al., 2008 } \\
\text { Parker et al., 2015 } \\
\text { Pedreschi et al., 2012 } \\
\text { Sayers et al., } 2016 \\
\text { Sayers et al., } 2018 \\
\text { Boo et al., 2018 } \\
\end{array}$ \\
\hline & $\begin{array}{l}\text { NLPQQ } \\
\text { Ara h } 2.0101, \\
\text { Ara h } 2.0201 \\
\text { Ara h } 2.0202\end{array}$ & $\begin{array}{l}\text { Arachis ipaensis (130454) } \\
\text { Arachis hypogaea (3818) } \\
\text { Arachis duranensis (130453) }\end{array}$ & $\begin{array}{l}\text { QqQ } \\
\text { QqQ } \\
\text { QqQ } \\
\text { QqQ } \\
\text { QqQ } \\
\text { QqQ } \\
\text { QqQ } \\
\text { QqQ } \\
\text { QqQ }\end{array}$ & $\begin{array}{l}543.3(+2) \\
543.3(+2) \\
543.3(+2) \\
543.3(+2) \\
543.6(+2) \\
543.3(+2) \\
543.3(+2) \\
543.3(+2) \\
543.8(+2)\end{array}$ & $\begin{array}{l}858.4 \\
858.4 \\
858.4 \\
858.4 \\
858.2 \\
858.4 \\
858.4 \\
858.4 \\
858.4 \\
\end{array}$ & $\begin{array}{l}y_{7^{+}}^{+} \\
y_{7^{+}} \\
y_{7_{7}^{+}} \\
y_{7^{+}}^{+} \\
y_{7^{+}}^{+} \\
y_{7^{+}}^{+} \\
y_{7}^{+} \\
y_{7}^{+}\end{array}$ & $\begin{array}{l}761.4 \\
761.4 \\
761.4 \\
761.4 \\
429.8^{*} \\
429.7 \\
761.4 \\
429.7 \\
633.3 \\
\end{array}$ & $\begin{array}{l}y_{6}{ }^{+} \\
y_{6}{ }^{+} \\
y_{6}{ }^{+} \\
y_{6}{ }^{+} \\
y_{7}^{++} \\
y_{7}^{++} \\
y_{6}^{+} \\
y_{7}^{++} \\
y_{5}^{+}\end{array}$ & $\begin{array}{l}633.3 \\
633.3 \\
633.3 \\
633.3 \\
633.3 \\
633.3 \\
- \\
- \\
\end{array}$ & $\begin{array}{l}y_{5}{ }^{+} \\
y_{5}{ }^{+} \\
y_{5}{ }^{+} \\
y_{5^{+}} \\
-y_{5}^{+} \\
y_{5}{ }^{+}\end{array}$ & $\begin{array}{l}\text { Parker et al., } 2015 \\
\text { Pedreschi et al., } 2012 \\
\text { Sayers et al., } 2016 \\
\text { Sayers et al., } 2018 \\
\text { Vandekerckhove et al } 2017 \\
\text { Planque et al., 2017b } \\
\text { Boo et al., 2018 } \\
\text { Planque et al., 2019 } \\
\text { Zhang et al., 2019 }\end{array}$ \\
\hline $\begin{array}{l}\text { Gly m } 5-\beta- \\
\text { Conglycinin } \\
\text { (Vicilin, } 7 \mathrm{~S} \\
\text { Globulin) }\end{array}$ & $\begin{array}{l}\text { LITLAIPVNKPGR } \\
\text { Gly } m 5.0101\end{array}$ & $\begin{array}{l}\text { Glycine max (3847) } \\
\text { Glycine soja (3848) }\end{array}$ & $\begin{array}{l}\mathrm{QqQ} \\
\mathrm{QqQ} \\
\mathrm{QqQ} \\
\mathrm{Q} \text {-Orbitrap }\end{array}$ & $\begin{array}{l}464.7(+3) \\
464.6(+3) \\
464.6(+3) \\
464.63(+3) \\
\end{array}$ & $\begin{array}{l}767.5^{\star} \\
767.5 \\
767.5 \\
- \\
\end{array}$ & $\begin{array}{l}y_{7^{+}}^{+} \\
y_{7^{+}} \\
y_{7^{+}}\end{array}$ & $\begin{array}{l}583.4^{*} \\
583.4 \\
583.4 \\
-\end{array}$ & $\begin{array}{l}y_{11^{++}} \\
y_{11^{++}} \\
y_{11}+\end{array}$ & $\begin{array}{l}476.3^{*} \\
476.3 \\
476.3 \\
- \\
\end{array}$ & $\begin{array}{l}\mathrm{yg}_{9^{++}} \\
\mathrm{yg}_{9^{++}} \\
\mathrm{y}^{++}\end{array}$ & $\begin{array}{l}\text { Houston et al., } 2011 \\
\text { Planque et al., } 2016 \\
\text { Planque et al., 2017b } \\
\text { Chen et al., 2019 }\end{array}$ \\
\hline
\end{tabular}




\begin{tabular}{|c|c|c|c|c|c|c|c|c|c|c|c|}
\hline & $\begin{array}{l}\text { QQQEEQPLEVR } \\
\text { Gly } m 5.0201\end{array}$ & $\begin{array}{l}\text { Glycine max (3847) } \\
\text { Glycine soja (3848) }\end{array}$ & $\begin{array}{l}\text { QqQ } \\
\text { Q- Orbitrap }\end{array}$ & $\begin{array}{l}692.3(+2) \\
692.34(+2) \\
\end{array}$ & 1127.6 & $\mathrm{yg}^{+}$ & 870.5 & $\mathrm{y}_{7}{ }^{+}$ & 613.4 & $\mathrm{y} 5^{+}$ & $\begin{array}{l}\text { Gu et al., } 2018 \\
\text { Chen et al., } 2019\end{array}$ \\
\hline & $\begin{array}{l}\text { DSYNLQSGDALR } \\
\text { Gly } m 5.0201\end{array}$ & $\begin{array}{l}\text { Glycine max (3847) } \\
\text { Glycine soja (3848) }\end{array}$ & $\mathrm{QqQ}$ & $669.8(+2)$ & 859.5 & $\mathrm{y}_{8}{ }^{+}$ & 746.4 & $y_{7}+$ & 618.3 & $\mathrm{y}_{6}{ }^{+}$ & Gu et al., 2018 \\
\hline & $\begin{array}{l}\text { DSYNLHPGDAQR } \\
\text { Gly } \mathrm{m} 5.0301, \\
\text { Gly } \mathrm{m} 5.0302\end{array}$ & Glycine max (3847) & QqQ & $458.2(+3)$ & 643.3 & $\mathrm{y}_{6}{ }^{+}$ & 546.3 & $\mathrm{y}_{5}{ }^{+}$ & 374.2 & $\mathrm{y}_{3}{ }^{+}$ & Gu et al., 2018 \\
\hline \multirow[t]{4}{*}{$\begin{array}{l}\text { Gly m } 6- \\
\text { Glycinin } \\
\text { (Legumin, } \\
\text { 11S Globulin) }\end{array}$} & $\begin{array}{l}\text { VFDGELQEGR } \\
\text { Gly } m 6.0101\end{array}$ & Glycine max (3847) & $\begin{array}{l}\text { QqQ } \\
\text { QqQ } \\
\text { QqQ } \\
\text { QqQ } \\
\text { QqQ } \\
\text { Q-Orbitrap }\end{array}$ & $\begin{array}{l}575.2(+2) \\
575.2(+2) \\
575.3(+2) \\
575.3(+2) \\
575.3(+2) \\
575.28(+2)\end{array}$ & $\begin{array}{l}903.2 \\
903.2 \\
903.2 \\
788.4 \\
788.4\end{array}$ & $\begin{array}{l}y_{8}^{+} \\
y_{8}^{+} \\
y_{8}^{+} \\
y_{7^{+}}^{+} \\
y_{7}^{+}\end{array}$ & $\begin{array}{l}219.2 \\
219.2 \\
489.2 \\
602.3 \\
602.3\end{array}$ & $\begin{array}{l}\mathrm{a}_{2}{ }^{+} \\
a_{2}{ }^{+} \\
y_{4}{ }^{+} \\
y_{5}{ }^{+} \\
y_{5}\end{array}$ & $\begin{array}{l}- \\
- \\
788.5 \\
789.4 \\
- \\
-\end{array}$ & $\begin{array}{l}- \\
y_{7}^{+} \\
b_{7}^{+}\end{array}$ & $\begin{array}{l}\text { Heick et al., 2011b } \\
\text { Heick et al., 2011a } \\
\text { Huschek et al., 2016 } \\
\text { Planque et al., 2017b } \\
\text { Planque et al., 2019 } \\
\text { Chen et al., 2019 }\end{array}$ \\
\hline & $\begin{array}{l}\text { SQSDNFEYVSFK } \\
\text { Gly } m 6.0101 \\
\text { Gly } m 6.0201 \\
\text { Gly } m 6.0301\end{array}$ & Glycine max (3847) & $\begin{array}{l}\text { QqQ } \\
\text { QqQ } \\
\text { Dual LIT } \\
\text { QqQ } \\
\text { Q-Orbitrap }\end{array}$ & $\begin{array}{l}725.7(+2) \\
725.7(+2) \\
725.8(+2) \\
725.8(+2) \\
725.83(+2)\end{array}$ & $\begin{array}{l}381.2 \\
381.2 \\
381.2 \\
772.4\end{array}$ & $\begin{array}{l}y_{3}{ }^{+} \\
y_{3}{ }^{+} \\
y_{3}{ }^{+} \\
y_{6}{ }^{+}\end{array}$ & $\begin{array}{l}1235.4 \\
1235.4 \\
716.8 \\
643.3\end{array}$ & $\begin{array}{l}\mathrm{y}_{10^{+}} \\
\mathrm{y}_{10^{+}} \\
{[\mathrm{M}+2 \mathrm{H}]^{++}-\mathrm{H}_{2} \mathrm{O}} \\
\mathrm{y}_{5}{ }^{+}\end{array}$ & $\begin{array}{l}- \\
1235.4 \\
480.3\end{array}$ & $\begin{array}{l}- \\
- \\
y_{10}+ \\
y_{4}^{+}\end{array}$ & $\begin{array}{l}\text { Heick et al., 2011a } \\
\text { Heick et al., 2011b } \\
\text { Pilolli et al., 2017a } \\
\text { Gu et al., } 2018 \\
\text { Chen et al., } 2019\end{array}$ \\
\hline & $\begin{array}{l}\text { ISTLNSLTLPALR } \\
\text { Gly m 6.0401, } \\
\text { Gly m 6.0501 }\end{array}$ & $\begin{array}{l}\text { Glycine max (3847) } \\
\text { Glycine soja (3848) } \\
\text { Glycine microphylla (45693) }\end{array}$ & $\begin{array}{l}\mathrm{QqQ} \\
\text { QqQQqQ } \\
\text { Q-Orbitrap }\end{array}$ & $\begin{array}{l}699.9(+2) \\
699.9(+2) \\
699.9(+2) \\
699.92(+2)\end{array}$ & $\begin{array}{l}984.6 \\
984.6 \\
1097.7 \\
-\end{array}$ & $\begin{array}{l}\mathrm{yg}^{+} \\
\mathrm{yg}^{+} \\
\mathrm{y}_{10^{+}}\end{array}$ & $\begin{array}{l}870.5 \\
870.5 \\
670.4 \\
-\end{array}$ & $\begin{array}{l}y_{8}^{+} \\
y_{8}^{+} \\
y_{6}{ }^{+}\end{array}$ & $\begin{array}{l}783.5 \\
783.5 \\
456.4 \\
-\end{array}$ & $\begin{array}{l}y_{7^{+}}^{+} \\
y_{7^{+}} \\
y^{+}\end{array}$ & $\begin{array}{l}\text { Planque et al., } 2016 \\
\text { Planque et al., 2017b } \\
\text { Montowska et al., } 2019 \\
\text { Chen et al., 2019 }\end{array}$ \\
\hline & $\begin{array}{l}\text { FYLAGNQEQEFLK } \\
\text { Gly } m 6.0101 \\
\text { Gly } \mathrm{m} 6.0201\end{array}$ & Glycine max (3847) & $\begin{array}{l}\text { Dual LIT } \\
\text { QqQ }\end{array}$ & $\begin{array}{l}793.9(+2) \\
793.9(+2)\end{array}$ & $\begin{array}{l}638.8 \\
638.8\end{array}$ & $\begin{array}{l}\begin{array}{l}y_{11^{++}} \\
y_{11} 1^{++}\end{array} \\
\end{array}$ & $\begin{array}{l}1163.6 \\
424.2\end{array}$ & $\begin{array}{l}y_{10^{+}} \\
b_{3}{ }^{+}\end{array}$ & $\begin{array}{l}1092.5 \\
283.1\end{array}$ & $\begin{array}{l}\mathrm{yg}_{9}^{+} \\
\mathrm{ag}_{2}{ }^{+}\end{array}$ & $\begin{array}{l}\text { Pilolli et al., 2017a } \\
\text { Hoffmann et al., } 2017\end{array}$ \\
\hline \multirow[t]{4}{*}{$\begin{array}{l}\text { Cor a } 9-11 \mathrm{~S} \\
\text { Seed Storage } \\
\text { Globulin } \\
\text { (Legumin- } \\
\text { Like) }\end{array}$} & $\begin{array}{l}\text { INTVNSNTLPVLR } \\
\text { Cor a } 9.0101 \text { (Q8W1C2) } \\
\text { Cor a } 9 \text { (AOAOAOP7E3) }\end{array}$ & Corylus avellana (13451) & $\begin{array}{l}\text { QqQ } \\
\text { QqQ } \\
\text { QqQ } \\
\text { QqQ } \\
\text { QqQ } \\
\text { QqQ } \\
\text { LIT-Orbitrap }\end{array}$ & $\begin{array}{l}720.9(+2) \\
720.9(+2) \\
721.1(+2) \\
721.1(+2) \\
720.9(+2) \\
720.9(+2) \\
720.9(+2) \\
\end{array}$ & $\begin{array}{l}1013.6 \\
1013.6 \\
1013.7 \\
1013.7 \\
1013.6 \\
1013.6 \\
-\end{array}$ & $\begin{array}{l}y_{g^{+}} \\
y_{9^{+}} \\
y_{9^{+}} \\
y_{9^{+}} \\
y_{g^{+}} \\
y_{9^{+}} \\
-\end{array}$ & $\begin{array}{l}484.4 \\
484.4 \\
484.4 \\
484.4 \\
899.5 \\
484.3 \\
-\end{array}$ & $\begin{array}{l}y_{4}{ }^{+} \\
y_{4}{ }^{+} \\
y_{4}{ }^{+} \\
y_{4}{ }^{+} \\
y_{8}{ }^{+} \\
y_{4} 4^{+}\end{array}$ & $\begin{array}{l}- \\
- \\
228.2 \\
228.2 \\
812.5 \\
- \\
- \\
\end{array}$ & $\begin{array}{l}- \\
- \\
b_{2}^{+} \\
b_{2}^{+} \\
y_{7}^{+} \\
- \\
-\end{array}$ & $\begin{array}{l}\text { Heick et al., 2011a } \\
\text { Heick et al., 2011b } \\
\text { Ansari et al., 2012 } \\
\text { Costa et al., 2014 } \\
\text { Planque et al., 2017b } \\
\text { New et al.,. 2018 } \\
\text { Korte et al., 2016 } \\
\end{array}$ \\
\hline & $\begin{array}{l}\text { ALPDDVLANAFQISR } \\
\text { Cor a } 9.0101 \text { (Q8W1C2) } \\
\text { Cor a } 9 \text { (AOAOAOP7E3) }\end{array}$ & Corylus avellana (13451) & $\begin{array}{l}\text { QqQ } \\
\text { QqQ } \\
\text { QqQ } \\
\text { QqQ } \\
\text { Dual LIT } \\
\text { Q-Orbitrap } \\
\text { QqQ } \\
\text { QqQ }\end{array}$ & $\begin{array}{l}815.5(+2) \\
815.5(+2) \\
815.6(+2) \\
815.6(+2) \\
815.4(+2) \\
815.4(+2) \\
815.4(+2) \\
815.4(+2)\end{array}$ & $\begin{array}{l}906.6 \\
906.6 \\
906.5 \\
906.5 \\
906.5 \\
906.5 \\
906.5\end{array}$ & $\begin{array}{l}y_{8}{ }^{+} \\
y_{8}{ }^{+} \\
y_{8} \\
y_{8}^{+} \\
y_{8}^{+} \\
y_{8}^{+} \\
y_{8}^{+}\end{array}$ & $\begin{array}{l}1019.5 \\
1019.5 \\
185.2 \\
185.2 \\
835.4 \\
1019.6 \\
1019.6\end{array}$ & $\begin{array}{l}y_{g^{+}} \\
y_{g^{+}} \\
b_{2}{ }^{+} \\
b_{2}{ }^{+} \\
y_{7}{ }^{+} \\
-y_{9}{ }^{+} \\
y_{9}{ }^{+}\end{array}$ & $\begin{array}{l}- \\
- \\
175.2 \\
175.2 \\
723.4 \\
- \\
723.4\end{array}$ & $\begin{array}{l}- \\
- \\
\mathrm{y}_{1}^{+} \\
\mathrm{y}_{1}^{+} \\
\mathrm{y}_{13^{++}} \\
- \\
\mathrm{y}_{13}{ }^{++}\end{array}$ & $\begin{array}{l}\text { Heick et al., 2011a } \\
\text { Heick et al., 2011b } \\
\text { Ansari et al.., 2012 } \\
\text { Costa et al., 2014 } \\
\text { Pilolli et al., 2017a } \\
\text { Pilolli et al., 2018 } \\
\text { Planque et al., 2017b } \\
\text { Planque et al., 2019 }\end{array}$ \\
\hline & $\begin{array}{l}\text { ADIYTEQVGR } \\
\text { Cor a 9.0101 (Q8W1C2) } \\
\text { Cor a } 9 \text { (AOAOAOP7E3) }\end{array}$ & Corylus avellana (13451) & $\begin{array}{l}\text { QqQ } \\
\text { QqQ } \\
\text { LIT } \\
\text { LIT } \\
\text { Dual LIT } \\
\text { QqQ } \\
\text { QqQ } \\
\text { Q-Orbitrap } \\
\text { QqQ } \\
\text { LIT-Orbitrap } \\
\text { QqQ } \\
\end{array}$ & $\begin{array}{l}576.3(+2) \\
576.3(+2) \\
577.0(+2) \\
577.0(+2) \\
576.3(+2) \\
576.3(+2) \\
576.3(+2) \\
576.3(+2) \\
576.3(+2) \\
576.3(+2) \\
576.3(+2) \\
\end{array}$ & $\begin{array}{l}689.4 \\
689.4 \\
689.0 \\
689.0 \\
689.4 \\
689.4 \\
689.4 \\
- \\
689.4 \\
- \\
689.4 \\
\end{array}$ & $\begin{array}{l}y 6^{+} \\
y 6^{+} \\
y 6^{+} \\
y_{6} 6^{+} \\
y_{6} 6^{+} \\
y_{6} 6^{+} \\
y_{6^{+}} \\
- \\
y_{6} 6^{+} \\
- \\
y 6^{+}\end{array}$ & $\begin{array}{l}852.5 \\
852.5 \\
567.0 \\
567.0 \\
567.3 \\
852.4 \\
852.4 \\
-852.4 \\
- \\
588.3 \\
\end{array}$ & $\begin{array}{l}y_{7^{+}}^{+} \\
y_{7^{+}} \\
{[M+2 H]^{++}-H_{2} \mathrm{O}} \\
{[M+2 H]^{++}-H_{2} \mathrm{O}} \\
{[M+2 H]^{++}-H_{2} \mathrm{O}} \\
y_{7^{+}} \\
y_{7}^{+} \\
-y_{7^{+}} \\
-y_{5}^{+}\end{array}$ & $\begin{array}{l}- \\
- \\
- \\
- \\
852.5 \\
588.3 \\
588.3 \\
- \\
-\end{array}$ & $\begin{array}{l}- \\
- \\
- \\
- \\
y_{7^{+}}+ \\
y_{5}{ }^{+} \\
y_{5}{ }^{+} \\
- \\
-\end{array}$ & $\begin{array}{l}\text { Heick et al., 2011a } \\
\text { Heick et al., 2011b } \\
\text { Bignardi et al., 2010 } \\
\text { Bignardi et al., 2013 } \\
\text { Pilolli et al., 2017a } \\
\text { Planque et al., 2017b } \\
\text { Gu et al., 2018 } \\
\text { Pilolli et al., 2018 } \\
\text { New et al., 2018 } \\
\text { Korte et al., 2016a } \\
\text { Planque et al., 2019 }\end{array}$ \\
\hline & $\begin{array}{l}\text { QGQVLTIPQNFAVAK } \\
\text { Cor a 9.0101 (Q8W1C2) } \\
\text { Cor a } 9 \text { (AOAOAOP7E3) }\end{array}$ & Corylus avellana (13451) & $\begin{array}{l}\text { QqQ } \\
\text { QqQ } \\
\text { QqQ } \\
\text { QqQ } \\
\text { QqQ } \\
\text { Q-Orbitrap }\end{array}$ & $\begin{array}{l}807.5(+2) \\
807.5(+2) \\
807.8(+2) \\
807.8(+2) \\
807.5(+2) \\
807.5(+2)\end{array}$ & $\begin{array}{l}1088.6 \\
1088.6 \\
874.6 \\
874.6 \\
1088.6 \\
-\end{array}$ & $\begin{array}{l}y_{10^{+}} \\
y_{10^{+}} \\
y_{8}{ }^{+} \\
y_{8}{ }^{+} \\
y_{10}\end{array}$ & $\begin{array}{l}874.6 \\
874.6 \\
186.2 \\
186.2 \\
437.7 \\
- \\
\end{array}$ & $\begin{array}{l}y_{8}{ }^{+} \\
y_{8}{ }^{+} \\
b_{2}{ }^{+} \\
b_{2}{ }^{+} \\
y_{8}^{++} \\
-\end{array}$ & $\begin{array}{l}314.2 \\
314.2 \\
- \\
-\end{array}$ & $\begin{array}{l}\mathrm{b}_{3}^{+} \\
\mathrm{b}_{3}^{+} \\
- \\
-\end{array}$ & $\begin{array}{l}\text { Heick et al., 2011a } \\
\text { Heick et al., 2011b } \\
\text { Ansari et al., 2012 } \\
\text { Costa et al., 2014 } \\
\text { Korte \& Brockmeyer, 2016b } \\
\text { Pilolli et al., 2018 }\end{array}$ \\
\hline
\end{tabular}




\begin{tabular}{|c|c|c|c|c|c|c|c|c|c|c|c|}
\hline & & & $\begin{array}{l}\text { QqQ } \\
\text { LIT-Orbitrap } \\
\text { QqQ } \\
\text { QqQ }\end{array}$ & $\begin{array}{l}807.5(+2) \\
807.5(+2) \\
807.5(+2)\end{array}$ & $\begin{array}{l}1088.6 \\
-1088.6\end{array}$ & $\begin{array}{l}\mathrm{y}_{10^{+}} \\
- \\
\mathrm{y}_{10}+\end{array}$ & $\begin{array}{l}987.6 \\
- \\
874.5\end{array}$ & $\begin{array}{l}\mathrm{yg}^{+} \\
- \\
\mathrm{y}_{8}{ }^{+}\end{array}$ & 874.5 & $\mathrm{y}_{8}{ }^{+}$ & $\begin{array}{l}\text { Planque et al., 2017b b } \\
\text { Korte et al., 2016a } \\
\text { Planque et al., } 2019 \\
\text { Korte et al. } 2019\end{array}$ \\
\hline \multirow{2}{*}{$\begin{array}{l}\text { Cor a 11 - 7S } \\
\text { Seed Storage } \\
\text { Globulin } \\
\text { (Vicilin-Like) }\end{array}$} & $\begin{array}{l}\text { LLSGIENFR } \\
\text { Cor a } 11.0101\end{array}$ & Corylus avellana (13451) & $\begin{array}{l}\mathrm{QqQ} \\
\mathrm{QqQ} \\
\mathrm{QqQ}\end{array}$ & $\begin{array}{l}524.9(+2) \\
524.9(+2) \\
524.8(+2)\end{array}$ & $\begin{array}{l}822.4 \\
822.4 \\
822.4\end{array}$ & $\begin{array}{l}y_{y^{+}}^{+} \\
y_{y^{+}} \\
y_{y^{+}}\end{array}$ & $\begin{array}{l}565.4 \\
565.4 \\
227.2\end{array}$ & $\begin{array}{l}y_{4}{ }^{+} \\
y_{4}{ }^{+} \\
b_{2}{ }^{+}\end{array}$ & $\begin{array}{l}199.3 \\
199.3\end{array}$ & $\begin{array}{l}\mathrm{a}_{2}{ }^{+} \\
\mathrm{a}_{2}{ }^{+}\end{array}$ & $\begin{array}{l}\text { Ansari et al.,. } 2012 \\
\text { Costa et al., } 2014 \\
\text { New et al., } 2018\end{array}$ \\
\hline & $\begin{array}{l}\text { AFSWEVLEAALK } \\
\text { Cor a } 11.0101\end{array}$ & Corylus avellana (13451) & $\begin{array}{l}\mathrm{QqQ} \\
\mathrm{QqQ} \\
\mathrm{QqQ} \\
\mathrm{QqQ}\end{array}$ & $\begin{array}{l}682.7(+2) \\
682.7(+2) \\
682.4(+2) \\
\end{array}$ & $\begin{array}{l}644.4 \\
644.4 \\
872.5\end{array}$ & $\begin{array}{l}y_{6} 6^{+} \\
y_{6} 6^{+} \\
y_{8}{ }^{+}\end{array}$ & $\begin{array}{l}402.3 \\
402.3 \\
743.5 \\
\end{array}$ & $\begin{array}{l}y_{4}{ }^{+} \\
y_{4}{ }^{+} \\
y_{7}^{+}\end{array}$ & $\begin{array}{l}191.3 \\
191.3\end{array}$ & $\begin{array}{l}\mathrm{a}_{2}{ }^{+} \\
\mathrm{a}_{2}{ }^{+}\end{array}$ & $\begin{array}{l}\text { Ansari et al., } 2012 \\
\text { Costa et al., } 2014 \\
\text { New et al., } 2018\end{array}$ \\
\hline \multirow{2}{*}{$\begin{array}{l}\text { Pru du 6 } \\
\text { Amandin, 11S } \\
\text { Globulin } \\
\text { Legumin-Like } \\
\text { Protein }\end{array}$} & $\begin{array}{l}\text { QQGQQEQQQER } \\
\text { Pru du } 6.0101\end{array}$ & Prunus dulcis (3755) & LIT & $694.0(+2)$ & 677.0 & & 685.0 & {$[\mathrm{M}+2 \mathrm{H}]^{++}-\mathrm{H}_{2} \mathrm{O}$} & - & - & Bignardi et al., 2010 \\
\hline & $\begin{array}{l}\text { TDENGFTNTLAGR } \\
\text { Pru } \frac{d u}{6.0201}\end{array}$ & Prunus dulcis (3755) & $\begin{array}{l}\text { QqQ } \\
\text { LIT-Orbitrap } \\
\text { QqQ }\end{array}$ & $\begin{array}{l}698.3(+2) \\
698.3(+2) \\
698.3(+3)\end{array}$ & $\begin{array}{l}936.5 \\
-879.5\end{array}$ & $\begin{array}{l}y_{g^{+}} \\
y_{8}{ }^{+}\end{array}$ & $\begin{array}{l}879.5 \\
-732.4\end{array}$ & $\begin{array}{l}y_{8}^{+} \\
y_{7}^{+}\end{array}$ & $\begin{array}{l}732.4 \\
- \\
-\end{array}$ & $\begin{array}{l}y_{7^{+}}^{+} \\
- \\
-\end{array}$ & $\begin{array}{l}\text { Planque et al., 2017b } \\
\text { Korte et al., 2016a } \\
\text { Planque et al., 2019 }\end{array}$ \\
\hline
\end{tabular}

